\title{
Sadomasochism: Descent into Darkness, Annotated Accounts of Cases, 1996-2014
}

\section{Robert Peters}

Morality in Media \& National Center on Sexual Exploitation, robert@moralityinmedia.org

Follow this and additional works at: https://digitalcommons.uri.edu/dignity

Part of the Applied Behavior Analysis Commons, Clinical Psychology Commons, Community-Based Research Commons, Courts Commons, Criminal Law Commons, Criminal Procedure Commons, Criminology Commons, Domestic and Intimate Partner Violence Commons, Gender and Sexuality Commons, Inequality and Stratification Commons, Judges Commons, Law and Gender Commons, Law and Society Commons, Sexuality and the Law Commons, Social Control, Law, Crime, and Deviance Commons, and the Social Psychology Commons

\section{Recommended Citation}

Peters, Robert (2018) "Sadomasochism: Descent into Darkness, Annotated Accounts of Cases, 1996-2014," Dignity: A Journal of Analysis of Exploitation and Violence: Vol. 3: Iss. 2, Article 2. https://doi.org/10.23860/dignity.2018.03.02.02

This Resource is brought to you for free and open access by DigitalCommons@URI. It has been accepted for inclusion in Dignity: A Journal of Analysis of Exploitation and Violence by an authorized editor of DigitalCommons@URI. For more information, please contact digitalcommons-group@uri.edu. 


\title{
Sadomasochism: Descent into Darkness, Annotated Accounts of Cases, 1996-2014
}

\author{
Abstract \\ A collection of accounts of sadomasochistic sexual abuse from news reports and scholarly and \\ professional sources about the dark underbelly of sadomasochism and the pornography that contributes \\ to it. It focuses on crimes and other harmful sexual behavior related to the pursuit of sadistic sexual \\ pleasure in North America and the U.K. It is intended to be a resource to educate people about how \\ sadomasochism can lead to harmful and even deadly sadistic sexual behavior.

\section{Keywords} \\ Sadomasochism, violence, cases, rape, children, abuse, murder, sadism, masochism

\section{Creative Commons License} \\ c) (i) $\Theta(9$ \\ This work is licensed under a Creative Commons Attribution-Noncommercial-No Derivative Works 4.0 \\ License.

\section{Acknowledgements} \\ Dignity thanks the following students for their time in editing this document: Hope Simas, philosophy and \\ gender and women's studies major, and Lily Lachapelle, psychology and gender and women's studies \\ major, and Arabic minor.
}




\section{DIGNITY}

Volume 3, Issue 2, Article 2, 2018
A JOURNAL ON

SEXUAL EXPLOITATION

AND VIOLENCE

https://doi.org/10.23860/dignity.2018.03.02.02

\section{SADOMASOCHISM: DESCENT INTO DARKNESS ANNOTATED ACCOUNTS OF CASES, 1996-2014}

Robert Peters

National Center on Sexual Exploitation (Morality in Media)

\section{KEYWORDS}

Sadomasochism, violence, cases, rape, children, abuse, murder, sadism, masochism

$\mathrm{T}$ This collection of accounts of sadomasochistic sexual abuse from news reports and scholarly and professional sources is about the dark underbelly of sadomasochism and the pornography that contributes to it. It focuses on crimes and other harmful sexual behavior related to the pursuit of sadistic sexual pleasure in North America and the U.K.

It is intended to be a resource to educate people about how sadomasochism can lead to harmful and even deadly sadistic sexual behavior.

I was prompted to write this paper by the release of the film Fifty Shades of Grey which portrays sadomasochism much in the same that Pretty Woman portrays prostitution (Hughes, 2015). This collection of press accounts is a complement to a paper I wrote more than a decade ago entitled The Link between Pornography and Violent Sex Crimes (Peters, 2004). Unlike the earlier paper, this paper is not about violent sex crimes as such.

\section{A warning about the content of this paper}

Although there is nothing in this paper that is pornographic or "erotic," the reader will be confronted repeatedly with graphic accounts of horrific sadomasochistic sexual abuse. Reading these accounts will be troubling and even unbearable for some readers; and if the reader finds descriptions of such abuse to be arousing, the paper may be a temptation to seek out pornography that depicts these types of abuse.

There is a tension between the need to fully inform the public and the need to withhold information for law enforcement purposes and to protect public sensibilities and privacy. The press has been known to "sensationalize" sex crimes. This leads to desensitization. But there are also occasions when the public needs to know the whole truth, however unpleasant, but is kept (partly) in the dark. This leads to a lack of resolve. 


\section{Be careful what you open the door of your life to}

For those contemplating sadomasochism as a means to "spice up" their sex lives, I say, "Be careful what you open the door of your life to because you don't know what S\&M will lead you or a partner into sooner or later." Craig Johnson (1985) described the problem this way:

Sadomasochism is indulged in...People like it. This is precisely one of the great dangers...A person tries it and finds it really gives him far out kicks. He may achieve orgasms like he's never achieved before. It happens. Then he may come back to it, again and again...S/M works. (So, does LSD). But...he may forget (or never learn) that there are other, more deeply satisfying means to sexual fulfillment. $\mathrm{S} / \mathrm{M}$ is very like using drugs to achieve sensation...He can become a 'pain junkie.' He may need more and more pain (or, if he is a sadist...to inflict more and more).

Sexual addictions of any kind are difficult to break free from (Kheriaty, 2015). In his monograph Pornography's Effects on Adults and Children (2001), Victor B. Cline described the problem this way:

The second phase was an escalation-effect. With the passage of time, the addicted person required rougher, more explicit, more deviant, and "kinky" kinds of sexual material to get their "highs" and "sexual turnons."...If their wives or girlfriends were involved with them, they eventually pushed their partners into doing increasingly bizarre and deviant sexual activities. In many cases, this resulted in a rupture in the relationship when the woman refused to go further - often leading to much conflict, separation or divorce.

Many of the accounts in this paper demonstrate that sadomasochist practices can start voluntary but lead to coerced behavior even murder. As in rape cases, trial judges and juries sometimes struggle to find perpetrators guilty in these situations,

\section{The role of pornography in sadistic sex crimes}

Sadomasochistic sexual abuse and pornography have much in common. If an individual becomes sexually aroused by binding a person and/or by forcing sex on a person, and/or by hurting, injuring or killing a person, he will also likely be sexually aroused by viewing depictions or reading descriptions of such behavior. Therefore, many men who commit sadistic sex crimes also view pornography that depicts bondage, rape, sexual torture, and sexual homicide (Cline, 2001).

Pornography, however, does not have to depict sexual violence to serve as fuel or a trigger for sadistic sexual violence. Imagine an attractive young woman walking by two young men who are sitting on a park bench. Both look up and see her walk by. One sees a person he would love to meet and spend time with. The other sees a woman he wants to hogtie, rape, torture and strangle. If the latter views nonviolent pornography, he can also see a woman he would like to overpower and violate.

I will add that just because a news report or court opinion does not state that the (alleged) perpetrator possessed or viewed pornography doesn't mean he didn't do so. These cases, however, demonstrate that many perpetrators regularly view sadomasochist pornography. 


\section{The link between sadomasochism and sex trafficking}

For almost a decade, I read detailed investigative reports prepared by two retired law enforcement agents who followed up on citizen complaints about possible violations of federal internet obscenity laws. The hardcore sexual conduct depicted on some websites was so horrific that it defied the imagination that the women had voluntarily consented to participate.

Of course, as Donna Hughes (2010) has pointed out in her article, "Sex trafficking of women for the production of pornography," women who perform in hardcore pornography for pay often consent without (fully) comprehending what they will be subjected to:

Women used in the production of commercial pornography in the U.S. are often subjected to violence and coercion during filming. Often, they protest and try to stop the filming or back-out before filming begins. Their protests are ignored, or they are pressured by their agent or the director to continue. Their experiences of coercion and trickery often meet the criteria for sex trafficking. Sex trafficking is a federal felony.

Regardless of whether the conduct meets the criteria for sex trafficking from start to finish or only after a point in time, the point is that as S\&M becomes appealing to more people and as the pornography they view and the conduct they engage in becomes more extreme, the demand for women trafficked into pornography and prostitution will increase. An article in Newsweek (Bennetts, 2011) reported that a study found that "...Over time, as a result of their prostitution and pornography use, sex buyers reported that their sexual preferences changed and they sought more sadomasochistic and anal sex." A later paper, "The slave and the porn star: Sexual trafficking and pornography" (Peters, Lederer, \& Kelly, 2012) found that "There may also be a relationship between consumption of or addiction to hardcore pornography that depicts the domination and abuse of women and paying to have sex with women trafficked into prostitution...”

\section{Mainstreaming of sadomasochism}

Fifty Shades of Grey is just the tip of the iceberg when it comes to "erotic" (if not pornographic) and/or "nonjudgmental" (if not celebratory) entertainment and news media portrayals of S\&M. Advertising, fashion, art, books, films, magazines, newspapers, music/rap videos, theater, and videogames have all helped popularize sadomasochism and make it appealing to young and old.

The truth of the matter is that sadomasochism is a sexual perversion that has caused incalculable harm and it isn't just hardcore pornographers who have blood on their hands.

I realize that this is an imperfect analogy, but it occurred to me as I worked on this collection that the marketing of Fifty Shades of Grey could be compared to the marketing of a "new nonprescription drug that can transform your pain into pleasure," without telling prospective buyers that the new drug is laced with morphine. In both situations, the movie and the drug are being marketed as something that will bring pleasure to your life. However, both products, although they may bring a certain degree of pleasure, have a certain probability of harmful effects both psychologically and physically. 


\section{This collection is just the tip of the iceberg}

This collection of accounts of sadomasochism would have been much longer if I had access to an online database of newspaper articles and court cases and I had a capable assistant(s) to help with online research and writing.

But even with access to a database and with assistance, it would be impossible to bring to light every crime and injurious incident motivated by sexual sadism. Among other things, this behavior is often not reported, and when it is reported, important details are often omitted in news articles and other accounts. Internet search engines also have limitations, and most news publications do not publish their entire archive online. To do justice to this topic it would require contacting, among others, law enforcement agents, crime reporters, forensic experts, mental health professionals, survivors, and family members.

And finally, as difficult as it was to research and put this collection together, it was almost as difficult to stop. Many more stories need to be retold and told until the harm of this activity sinks in. Sadomasochistic sexual abuse is not harmless fun. 


\section{TABLE OF CONTENTS}

$\begin{array}{lr}\text { “Consensual” Sadomasochism Gone Awry: Adult Victims } & 6 \\ \text { "Consensual” Sadomasochism Gone Awry: Child Victims } & 18 \\ \text { Sadomasochism: Impact on Marriages } & 19 \\ \text { Sadomasochism: Impact on Careers } & 24 \\ \text { Bondage, Rape, Torture \& Murder } & 30 \\ \text { Bondage, Rape, Torture and Murder: Adult Victims } & 31 \\ \text { Bondage, Rape, Torture and Murder: Child Victims } & 72 \\ \text { Sex Trafficking } & 99 \\ \text { Sex Trafficking: Adult Victims } & 99 \\ \text { Sex Trafficking: Child Victims } & 104 \\ \text { Mainstreaming of Sadomasochism } & 108 \\ \text { Advertising/Fashion/Magazines } & 110 \\ \text { Arts } & 111 \\ \text { Books } & 112 \\ \text { Films } & 113 \\ \text { Music/Rap } & 117 \\ \text { Newspapers } & 118 \\ \text { Television programs } & 119 \\ \text { Theater } & 121 \\ \text { Videogames } & 122\end{array}$




\title{
“CONSENSUAL" SADOMASOCHISM GONE AWRY: ADULT VICTIMS
}

\begin{abstract}
"Student: Sex was sadomasochistic role playing, not rape." CBS News, April 2, 2015, http://www.cbsnews.com/news/expelled-george-mason-university-student-sex-was-sadomasochistic-role-playing-not-rape/. "A student expelled from George Mason University for violating its sexual misconduct policy is suing in federal court to clear his name, arguing that an encounter with a girlfriend was sadomasochistic role playing, not sexual assault...The student says he had been in a longstanding relationship with the woman, and that they frequently engaged in sadomasochistic role playing that involved using a safe word if one or the other wanted to stop...The sexual misconduct allegations...stem from an October 2013 encounter with the couple in the male student's dorm room...At one point, according to the lawsuit, she pushed him away but didn't invoke her safe word... According to the lawsuit, the couple remained romantically involved for several months, but they broke up after she found that he had been cheating on her. It was only then that she filed a complaint against him, according to the suit."
\end{abstract}

\begin{abstract}
"Married architect who had fetish for stabbing women during sex is found guilty of murdering mentally ill child care worker..." Thomas Burrows. Daily Mail (UK), March 3, 2015, http://www.dailymail.co.uk/news/article3015044/Married-Irish-architect-fetish-stabbing-women-sex-guilty-murderingmentally-ill-childcare-worker-Dublin-mountains.html. "A married architect with a fetish for stabbing women during sex has been found guilty of murdering a mentally ill child care worker...The trial of the architect and family man was a graphic depiction of bloodlust and unnerving perversion. A huge swathe of evidence involved detail of BDSM sex, the 'Gorean' lifestyle of people living out a slave-master philosophy and a window into the life of a sexual deviant...Such was the shocking nature of some videos, photos and documents revealed in court...In one, [Victim] was bound, her feet in chains and her arms behind her back, while a gag muffled her screams as she was repeatedly stabbed...in the abdomen from behind...Thousands of disturbing text messages...revealed the unwavering control and power her 'Sir' [Defendant] had over his Slave [Victim] and the mental torment she suffered throughout their sexual relationship...In one text to [Victim] he wrote: 'I want to stick my knife in flesh while I am sexually aroused. Blood turns me on and I'd like to stab a girl to death some time.' Another said: 'My urge to rape, stab or kill is huge. You have to help me control or satisfy it.' Images and links from a phone [Defendant] owned included women being stabbed, strangled or killed, some of which came from a gore website..."
\end{abstract}

"Trucker found not guilty of murder viewed disturbing porn prior to prostitute's death." Tony Blais. Edmonton Sun, March 26, 2015, http://www.edmontonsun.com/2015/03/25/truck-found-not-guilty-of-murderviewed-disturbing-porn-prior-to-prostitutes-death. "An Edmonton jury that recently found an Ontario trucker not guilty of murdering a prostitute...did not know he had accessed disturbing porn websites. According to court documents...[Defendant], 46, used his laptop computer in the days leading up to the...death of [Victim], 36, to browse Internet sites containing content that was 'sexual in nature' and depicted 'women being tortured.' The computer evidence - which was referred to in a preliminary hearing as well as pre-trial hearings in the case - was not presented to the jury as a result of an agreement by Crown and defence that it was not admissible. A police computer forensic examiner report says a website with 
pictures displaying women with speculums and various other objects inserted into their vaginas and another showing a collection of photos in which females were being tortured had been accessed on the laptop. At trial, the Crown argued that [Defendant] had either fatally stabbed [Victim] in the vagina with a sharp-edged instrument or sexually assaulted her without consent. The defence argued it was an accidental death that was the result of a consensual sexual episode of fisting."

"Man who dressed as TSA agent during S\&M choked girlfriend: prosecutors.” Rebecca Rosenberg. New York Post, March 3, 2015, http://npost.com/ 2015/03/17/woman-claims-sm-loving-boyfriend-choked-her/. "A Manhattan lawyer who liked to dress as an airport security screener during S\&M sessions with his girlfriend wound up choking and threatening her with a knife, prosecutors said...During pretrial hearings, prosecutors said the couple made a sex tape where he pretended to be a 'TSA agent, searching her body cavities,' papers state. [Defendant] also had 20 homemade porn videos featuring him choking, waterboarding and torturing women, mostly prostitutes, prosecutors added... But those details weren't allowed at trial, after [his] defense lawyer...objected. Instead, Monday's testimony centered on [the Alleged Victim]... She tearfully testified about how she had shown up at his apartment...to break up with him - and explained that things quickly turned sour...'He was so angry that he grabbed me really fast and held my throat really tight,' she said. He let go, then retrieved a Bowie knife, she said..." [Author's note: A jury found Defendant not guilty.]

“[M] urder trial enthralled Seacoast.” Rod Doherty. Seacoastonline.com, December 28, 2014, http://www.seacoastonline.com/article/20141228/NEWS/ 141229421/101017/NEWS. “...To recap:...University of New Hampshire co-ed [Victim], 19, was killed and raped after she was dead...[Defendant] was arrested and charged with her murder and rape...[H]is live-in, teen, girlfriend [Defendant2], was arrested for her part in the murder. Ultimately, the investigation into the... murder and trial of [Defendant] was to put on display a salacious sexual lifestyle... Testimony included descriptions of dark fantasy personalities, online sex sites, lurid letters describing and requesting sex acts, sadomasochism, bondage, multiple sex partners, dominants, submissives, and slave sex fetishes. This all happened because of a presumption gone bad that [Victim] would join in a sexual relationship with [both Defendants]. [Victim] was invited to visit the couple in their Dover apartment for an evening of 'socializing.' The invitation was from her new friend at work, [Defendant2], who at [Defendant's] direction, had been told to find and bring home a woman to his liking to join in their sexcapades. The plan ended with [Defendant] going into a rage when his twice-requested desire to have [Victim] join in sex acts was declined. Attacking from behind by putting a rope around her neck, [Defendant] strangled the young woman and raped her after [Defendant2] confirmed the girl was dead." [Author's note: Defendant1 was convicted of rape and murder. He has appealed his conviction.]

“Testimony: Clarksville woman's slaying sex-related.” Tavia Green. LeafChronicle, July 3, 2014. "Kristin Wilkerson described in court...how her roommate, [Victim], was hung up, gagged and continuously beaten for four hours, sustaining multiple kicks, punches and strikes with a metal pole, a rod and whip-like devices at the hands of three other roommates. Clarksville Police found [Victim], 39, dead in the back room of her home... and police have charged four of her six roommates with criminal homicide...The biggest question was whether [Victim] was murdered during a BDSM session (bondage, discipline, sadism and masochism) that went too far, or if she was brutally beaten to death and murdered in cold blood...Robert 
Nash, assistant district attorney, called numerous law enforcement agents to testify, but Wilkerson, an eyewitness, offered a good deal of insight...Wilkerson, who lived in the home for a year and a half, said [Victim] was known to be a 'house slave.' She desired to get into the BDSM lifestyle...[Victim] was beaten on June 25 by her roommates, but on June 26 the motives were different, according to testimony. Detective Ewing testified that [a male Defendant] admitted to him that he went into a rage after he suspected [Victim] was trying to kill him and his girlfriend." Four roommates were indicted for murder (Green, 2014).

“Judge tells Soho tub-strangle jury to disregard 'speculative' 'rough sex' defense." Laura Italiano. New York Post, July 11, 2013, http://nypost.com/2013/07/11/judge-tells-soho-tub-strangle-jury-to-disregard-speculative-rough-sex-defense/. “The forbidden 'rough sex' defense has reared its head once more in the Soho House tub-strangle trial - this time in the deliberations room. 'There's no evidence in this case regarding rough sex,' Manhattan Supreme Court Justice Bonnie Wittner told jurors..., warning them away from the dicey defense as the sensational trial entered its third day of deliberations. Before going home last night, jurors had asked that testimony be read back today relating to 'sex and rough sex' between accused strangler [Defendant], 27, and his alleged victim...[Defendant] has been barred from claiming that rough sex prior to her death could explain away the fingerprint-sized bruises on [Victim's] neck, and her bloodshot eyes....Still, defense lawyer Jeffrey Hoffman has repeatedly tried to insinuate, in questioning...that 'rough sex' could provide an innocent explanation for the worst of the forensics...'We have crazy chemistry - too crazy,' [Victim] had texted a friend in the weeks before her death...'He wants porn sex,' she'd complained." [Author's note: Defendant was found guilty of second degree murder. He appealed his conviction.]

"Mother Says Man's Sadomasochistic Sex with Mentally Ill Daughter Was Abuse, Takes Case to Supreme Court." Alaine Griffin. Hartford Courant, March 3, 2013, http://articles.courant.com/2013-03-13/news/hc-sadomasochism-case-20130312_1_mental-health-online-relationship-supreme-court. "[Mother] said she never thought twice about the man her adult daughter, [Victim], met through Internet chat discussions. [Defendant]...appeared to be helping [Victim] learn how to use her new computer - something her doctor thought would be a good form of therapy for [Victim], who struggled with mental health issues...But when [Mother] noticed red welts and marks on [Victim's] neck..., her daughter made a revelation: [Victim], then 32, was having sex with [Defendant] at a...facility where [Victim] was learning to live on her own. And it wasn't just any sex. She was involved in sadomasochism that included...being gagged, spanked and whipped. Court records said that during sex, [Victim] sometimes wore a dog collar and was led around by a leash...[Mother] said she was 'beyond stunned' because her daughter's...disabilities were obvious...[Mother] went to the police, but [Defendant], 49, was never...arrested... [Mother] sued..., charging that...[Victim's] mental health prevented her from consenting to such a relationship...[Defendant] argued during the 2009 trial that [Victim]...was an adult capable of making intelligent choices in matters relating to sex and that she had consented...Superior Court jurors...ruled in [Defendant's] favor...In her appeal, [Mother] said the trial judge wrongly permitted evidence of [Victim's] consent to reach the jury. The appeal says the probate court's appointment of [Mother] as [Victim's] conservator constituted a judicial determination that [Victim] was incompetent..." [Author's 
note: The Connecticut Supreme Court ordered a new trial. The second jury found in favor of the victim.]

"He whipped, she snapped." Jamie Schram \& Jean MacIntosh. New York Post, August 15, 2012, http://nypost.com/2012/08/15/he-whipped-she-snapped/. "She enjoyed the daily morning whippings - but she did not like being kicked to the curb by her beloved master. [Defendant] embraced a role as live-in fetish slave to dominating [Defendant], playing out a bondage fantasy similar to college student Anastasia Steele and older Christian Grey in the erotic novel Fifty Shades of Grey. But it all took a twisted turn when [Defendant], 27, found out ['Victim'], 53, had been training his whips on her replacement. The submissive [Defendant] exploded in a fit of rage, law-enforcement sources said, allegedly shattering ['Victim's'] car windshield and bombarding him with threats...[Defendant]...was arraigned...on charges of stalking, criminal mischief and aggravated harassment...She was his live-in slave for about three years, the source said. 'Basically, she was there to serve his sexual needs. She's his toy, his fetish slave.' At one downtown fetish event, a source recalled ['Victim'] openly whipping [Defendant] and boasting, 'She has had a lot of practice. I whip her every morning...'...Law-enforcement sources said [the] relationship took a twisted turn when she discovered he was seeing someone else."

"George Weber butcher convicted of murder." Thomas Tracy. Brooklyn Daily, November 6, 2011, http://www.brooklyndaily.com/stories/2011/46/ all_gaveltogavel_2011_11_18_bk.html. “The 19-year-old male prostitute accused of stabbing WABC newscaster George Weber 50 times during a kinky sex romp...was convicted of murder...[Defendant] met Weber...through a Craigslist ad. The teen agreed to come to the older man's... apartment...knowing he would be paid for sex...[Defendant's] attorneys claim that the teen was defending himself when he killed Weber - who had wanted to have rough sex with the teen. In a videotaped confession, [Defendant] giggled as he recalled Weber's desires to be bound and smothered. But things got out of control... when Weber pulled a knife, [Defendant] claimed...[Defendant's] lawyer made an issue out of Weber's alleged interest in bondage and rough sex. He also claimed the newscaster had plied the teen with booze and cocaine before taking him to his bedroom."

“'Killer' rep for S\&M'er.” Jamie Schram. New York Post, September 13, 2011, http://nypost.com/2011/09/13/killer-rep-for-smer/. “...Leather-loving [Dominatrix], whose lawyer boyfriend was shot and killed three years ago by a crazed client, just found her newest beau dead in the attic. The 29-year-old [Dominatrix]...made the horrific discovery...in their home..., police said... No foul play is suspected, said an Upper Darby Police Department spokesman. [Victim] was a 'heavy rubber fetishist,' said a source close to the couple who said [Dominatrix] specialized in 'oxygen deprivation."”

“Judge in Craigslist 'sex-slave master' case says consensual S\&M can be criminal." Kirstan Conley. New York Post, May 11, 2011, http://nypost.com/2011/03/11/judge-in-craigslist-sex-slave-master-case-says-consensualsm-can-be-criminal/. "S\&M can be criminal even if it's consensual, a Brooklyn judge said today during the arraignment of a self-described Craigslist sex-slave master...'In these types of situations,...both the consensual and criminal can coexist,' the judge said. 'At some point, it can change to a situation where no means no. There comes a time when...they become...criminally dangerous.' Still, the judge said, 'I'm not denying that at some point and at some time this abuse and torture 
was consensual.' The victim says she was raped and held hostage...for more than a week last month after she answered an ad to live in New York for free in exchange for housekeeping duties. [Defendant] says he and the woman were into sadomasochistic role-playing. But prosecutors say [Defendant]...flogged the woman and kept her chained to a radiator against her will... [Defendant] also...forced her to drink large amounts of water while forbidding her from relieving herself, they said...[Defendant's] lawyer...said the pair knew each other for two years and had a consensual relationship. He said the relationship only blew up after Hopkins kicked her out of his apartment for heavy drinking." [Author's note: The case was dismissed when the woman chose not to testify.]

Her Majesty The Queen v. J.A., 2011 SCC 28 (Sup. Ct. of Canada), http://scc-csc.lexum.com/scc-csc/scc-csc/en/item/7942/index.do. "[I]n the course of sexual relations, J.A. placed his hands around the throat of his long-term partner K.D. and choked her until she was unconscious...At trial, K.D. testified that she consented to J.A. choking her, and understood that she might lose consciousness. She stated that she and J.A. had experimented with erotic asphyxiation, and that she had lost consciousness before. When K.D. regained consciousness, her hands were tied behind her back, and J.A. was inserting a dildo into her anus...K.D. made a complaint to the police two months later and stated that while she consented to the choking, she had not consented to sexual activity...She later recanted her allegation...The trial judge convicted J.A. of sexual assault. A majority of the Court of Appeal...dismissed the charges." [Author's note: In restoring respondent's conviction for sexual assault, a majority of the Supreme Court of Canada reasoned that Parliament defined consent in a way that requires the complainant to be conscious throughout the sexual activity in question. Parliament's definition of consent does not extend to advance consent to sexual acts committed while the complainant is unconscious.]

"Businessman chokes to death during S\&M session...." Daily Mail (UK), October 13, 2010, http://www.dailymail.co.uk/news/article-1319103/Businessman-Lionel-Webster-chokes-death-S-M-session-pensioner-couples-dungeon.

html. "A businessman died after he was strangled by his own S\&M collar during a role-playing bondage game that went wrong, an inquest has heard. [Victim]...was found by paramedics...slumped on the floor of a garage at the home of pensioners [Defendant], 74, and his dominatrix wife, [Defendant2], 68. [Victim], 61, was found shackled to a wooden frame by several chains - one of which was around his genitals. He was wearing a Guantanamo Bay-style boiler suit, knee-high stiletto boots and a blindfold. At an inquest...on Friday, [Defendant2] explained [Victim] had been tied up, blindfolded and told to wear a balaclava. She said he had been asked to be treated like a military prisoner that had gone AWOL and needed to be punished...The couple were originally arrested on suspicion of murder at the time of the incident but prosecutors later dropped the case as there were no signs of gross negligence or assault."

“...Ex-Lover...Pleads Guilty To Killing...NYPD Forensic Investigator.” Colleen Long. Associated Press, May 21, 2010, http://www.huffingtonpost. com/2010/05/21/gary-mcgurk-ex-lover-plea_n_584620.html. “The ex-boyfriend of a police forensic investigator whose naked body was found tied to a bed in a pool of blood pleaded guilty...to manslaughter...[Defendant] admitted he hit [Victim] over the head and stabbed her in the neck in her apartment on April 27, 2009, prosecutors said... [Defendant], 24, faces between 29 and 37 years in prison when he's sentenced...[Defendant] claimed he and [Victim], 24, had rough sex, tying up 
and choking each other, according to court documents....[Victim] was found naked, tied to the bed with burn marks on her abdomen. She had been stabbed and hit with a blunt object."

"Convicted of murder, [Defendant] back in York County on DUI charges." Rick Lee. Daily Record, February 28, 2010, http://www.in york.com/local/ci_14484126. "Retired York City Police Detective Dennis Williams remembers stepping into the crime scene...In front of Williams was the decomposing mutilated body of a woman tied to a bed. Now, the man who committed that crime is back in York County. [Defendant], 42, served the maximum of a 10- to 20year state prison sentence for the...bondage-suffocation murder of 39-year-old [Victim]. Then 21 years old, [Defendant] had cut off body parts and had sliced open her abdomen...And sitting in his office in the Judicial Center, District Attorney Tom Kearney - who was [Defendant's] defense attorney - wants to know, 'Why he is back in my house?'...Former York County District Attorney Stan Rebert...recalled...that medical evidence could not establish [Victim's] injuries occurred before her death. Without that proof, he said, he could not support the aggravating factor of torture for a death penalty conviction...'The prosecution focuses on the event,' Kearney said last week. 'My goal as defense counsel was to show this didn't happen in a vacuum. I thought that's what it was - third-degree (murder.) And, the jury agreed.' Kearney recalled that [Defendant] and [Victim] had an ongoing sexual relationship that included consensual bondage and rough sex. Both were extremely intoxicated... Kearney said he still believes [Defendant] had no intent to kill [Victim]. As he argued at trial, he believes [Defendant] mentally 'snapped' when he realized [Victim] was dead, accounting for the mutilation."

United States $v$. Marcus, 628 F.3d 36, at 39-40 (2nd Cir. 2010), http://caselaw.findlaw.com/us-2nd-circuit/1547193.html. "From October 1998 through approximately June 1999, Marcus and the complaining witness, Jodi, engaged in a consensual relationship that involved bondage, dominance/discipline, submission/sadism, and masochism ('BDSM')...This included being considered Marcus's 'slaves' and being subjected to various physical and sexual 'punishments.'...[Defendant]... maintained a membership BDSM website...which contained pictures of Jodi and other women participating in BDSM activities and fantasy diary entries written about these activities. By October 1999, the nature of this arrangement changed. Because Jodi refused to recruit her younger sister to become one of Marcus's 'slaves,' Marcus inflicted upon Jodi a 'punishment' that was the most physically severe that she had experienced to date. Jodi testified that...thereafter her relationship with Marcus became nonconsensual. According to Jodi, she began to feel 'trapped' and 'full of terror.'...In January 2000, Marcus instructed Jodi to move to New York...Jodi testified that upon her move to New York, Marcus directed her to create and maintain a new commercial BDSM website... Jodi indicated that she worked on the site for approximately eight to nine hours per day...Marcus received all revenues from the website...Although Jodi did not want to work on the website..., she did so because she feared the consequences of her refusal. Marcus created and fueled Jodi's fear by physically and sexually 'punishing' her...These punishments were photographed, and the pictures were posted on [Website]...Although Jodi's relationship with Marcus had become nonconsensual, she remained with Marcus out of fear of his reaction if she left. Specifically, at one point, when Jodi told Marcus that she was unhappy and could not continue with the arrangement, Marcus threatened to send pictures of Jodi to her family and the media. In March 2001, Jodi told Marcus that she wanted to leave. 
In response, Marcus told Jodi that she had to endure one final punishment. In the basement of a Long Island residence, Marcus inflicted a severe punishment on Jodi, including banging her head against a basement ceiling beam, tying her hands and ankles to the beam, beating her and whipping her while she was hanging from the beam, drugging her with Valium, and inserting a large surgical needle through her tongue. After inflicting this beating, Marcus let Jodi off the beam, took her to a bedroom, and had sexual intercourse with her. Marcus photographed Jodi throughout the punishment and instructed her to write and post on the website a diary entry...Jodi testified that, after this incident, she felt broken, surrounded by fear and terror, and trapped in this relationship with Marcus." [Author's note: A jury found Marcus guilty of forced labor and sex trafficking, but the conviction was reversed on appeal. The U.S. Attorney declined to retry the sex trafficking charge, but defendant was convicted a second time on the forced labor charge.]

“Lawyer's deadly secret.” Jamie Schram. New York Post, December 24, 2008, http://nypost.com/2008/12/04/lawyers-deadly-secret/. "An attorney at one of the city's most prestigious law firms - who had a secret passion for S\&M - was shot to death by a rival for the affections of a brilliant Ivy League stunner who moonlights as a dominatrix, police sources said yesterday. After fatally shooting [Victim], musclebound madman [Perpetrator] kidnapped the white-shoe lawyer's girlfriend...who goes by the name Jade Vixen in fetish circles. [Perpetrator], 42, who was obsessed with [the dominatrix]...[shot] himself...[Victim's] secret leatherloving lifestyle - seen on photos posted on fetish Web sites - turned out to be his downfall...[T]he petite dominatrix...specialize[d] in tickle torture, nipple play and 'sissy slut training."'

"Family sues after man dies in S\&M sex." Jamie Schram. Telegraph (UK), October 12, 2007, http://www.telegraph.co.uk/news/worldnews/1565995/Family-sue-after-man-dies-in-SandM-sex.html. "The family of a British man who flew to America for a sadomasochistic bondage session are taking legal action after he suffocated and died. Wrapped tightly in heavy plastic with a leather hood over his head and breathing via a thin plastic straw, [Victim] was then shut in a cupboard in the bondage 'playroom' of [Mr.] LeBlanc, a...man he had met through the internet. His body was discovered...two months later. Mr. LeBlanc...detailed his responsibility in the fatal bondage session in a suicide note... In what could prove to be a test case in determining responsibility in consensual, but dangerous sex, [Victim's] family are suing LeBlanc's estate for wrongful death... [A] lawyer for the estate, said [Victim] knew the risks. "What occurred was an act or actions between two consenting adults...' he said. [L]awyers for [Victim's] estate insist [Victim] did not know about Mr LeBlanc's reputation as an 'extreme edge player' in the world of bondage and sadomasochism. [Victim's] lawyer, said: 'Just because you are agreeing that you will allow someone to tie you up temporarily as part of role-playing doesn't mean that you are consenting to be killed or to be left alone or to be abused."”

“Officials say he confessed." Andrew Strickler \& Christine Armario. New York Newsday, June 1, 2007. "A...man charged with strangling a married friend and setting her house on fire told detectives his victim died during 'rough consensual sex,' a...prosecutor said yesterday...[Defendant] confessed how he used a piece of clothing...to bind [the Victim's] mouth and neck during sex, and that she collapsed on the floor, [Prosecutor] said. 'He subsequently realized that she was dead and tried to set the house on fire to cover up the crime,' [Prosecutor] said...The criminal complaint...quotes [Defendant] describing [Victim's] death, 'I was holding the 
clothing with both hands and [the woman] moved the clothing down around her neck...I saw blood on her mouth...and realized she was dead,' the document states." [Author's note: The Defendant subsequently pleaded guilty to manslaughter and arson.]

"Dominatrix acquitted of manslaughter." Raja Mishra. Boston Globe, January 31, 2006, http://www.boston.com/news/local/articles/2006/01/31/dominatrix_acquitted_of_manslaughter/. “...[Defendant] was acquitted yesterday of involuntary manslaughter in the death of a...man who prosecutors said suffered a fatal heart attack while strapped to a bondage rack in her...condominium. Prosecutors had argued that [Defendant]...did nothing to help [Victim]...as he died...out of fear that calling authorities would have jeopardized her dominatrix business. The prosecutors said she and a boyfriend chopped up [Victim's] 275-pound body and dumped the parts in a trash bin...[The Victim's] corpse was never found, which produced a rare legal situation. Prosecutors were forced to try [Defendant] for manslaughter without irrefutable proof that a man had died, his body...The...jury deliberated for eight hours over two days before finding [Defendant] not guilty of involuntary manslaughter and dismemberment...The prosecution's case...rested on an alleged confession by [Defendant]. Several police investigators testified that [Defendant] had admitted to watching [Victim] die on the bondage rack without calling for medical help and then dismembering his body...But the confession was not recorded, and investigators could not produce any notes documenting the confession...."

“S\&M fiend's big flub: Kidnapped the wrong gal." Dareh Gregorian. New York Post, April 9, 2005. "It was the kind of mistake anybody could make - an upstate man says he accidentally tried to kidnap the wrong woman to bring home to be his sex slave for a month. [Defendant] says he thought he was kidnapping 'Judith,' an S\&M aficionado he'd chatted with over the Internet and who fantasized about getting abducted and forced into prostitution. Instead, he grabbed [Victim], who'd been out riding her bicycle near her country home...The conviction was overturned this week. A state appeals court ruled that the trial court judge [wrongly] told jurors they should consider not only whether [Defendant] actually believed his victim had agreed to the abduction, but whether a reasonable person could have made the same mistake.”

“Ongoing Consent: A Proposed Model for Consent to Assault in the S/M Context." Naria K. Santa Lucia. Carceral Notebooks 1:133-150, 2005, http://www.thecarceral.org/consent.pdf. "In the summer of 1996, [Defendant], a graduate student at Columbia University met a female Barnard College student in an online chat room. Over the course of the following months, the two exchanged numerous emails on various subjects, including their mutual interest in sadomasochistic practices (S/M). Specifically, the woman described her fantasy of being tortured and admitted to past $\mathrm{S} / \mathrm{M}$ relationships. In November of that year, the two arranged to meet at [Defendant's] apartment with the expectation of practicing $\mathrm{S} / \mathrm{M}$ together. During this initial encounter, the woman agreed to be tied to [Defendant's] futon. However, she later alleged that she did not consent to what followed - for the next 20 hours, [Defendant] poured hot candle wax all over her body, bit her, and shoved an object and/or his penis into her rectum. Although she invoked the 'safe word,'... and although she yelled so loud that his neighbors reported 'screams coming from the apartment,' [Defendant] continued...Following the encounter, the woman reported the incident to police, and [Defendant] was charged with kidnap, assault, and sexual assault. At the trial level, the court 
rejected [Defendant's] argument of consent as a defense to the allegations. Therefore...the judge excluded the e-mail correspondence between [Defendant] and the victim. [Defendant] was convicted on all counts by the trial court. On appeal, the Appellate Division, agreed in dicta that 'consent is no defense to assault.' However, in a split decision, the court held that the emails were 'highly probative as to [Defendant's] belief that consent to these activities existed'..." [Author's note: The case was never retried because the woman refused to testify again.]

"Porn model sought fame, found death: Photographer is charged...." Keith Herbert \& Oliver Prichard. Philadelphia Inquirer, March 25, 2004, http://articles.philly.com/2004-03-25/news/25383276_1_stab-wounds-taylorsumers-jennifer-mitkus. "[Victim] traveled alone to cities across North America, looking to hit it big in adult entertainment by performing and posing in hard-core films and photo shoots that paid up to $\$ 1,000$ per day...Her last trip was to Conshohocken, where photographer [Defendant] kept a basement apartment...filled with bondage devices and fake blood. The burly photographer and platinum-blond actress...found each other on the Internet, where would-be porn stars often sell their services to photographers... [P]olice charged [Defendant] with killing [Victim], slashing her throat from ear to ear, and dumping her nude body in a ravine...[Victim] was found gagged with a sexual device: a red ball near her mouth and leather straps affixed to her head ...[Victim's father] said his daughter was working in adult entertainment to pay for college." [Author's note: Defendant pleaded guilty to third-degree murder, admitting he killed Victim after a dispute over his inability to pay her.]

"Cannibal 'had porn at home." Birmingham Post (UK), January 6, 2004. "Investigators found hundreds of violent and pornographic images on the computer of a German who has confessed to killing a man and eating his flesh, an official testified at his murder trial yesterday. Volker Kegel, an officer with Hessen state criminal authorities, told the court in Kassel the images found ranged from homosexual pornography to torture...Prosecutors say the killing was sexually motivated and filed murder charges against [Defendant], despite concluding that the killer had the victim's consent. [Defendant] has confessed in detail to killing [Victim] at his home."

State v. Van, 688 N.W.2d 600, 608-610 (Neb. 2004), https://www.courtlistener.com/opinion/2204642/state-v-van/. "Van was charged in a five-count information with sexual assault in the first degree, assault in the first degree, assault in the second degree, first degree false imprisonment...All of the charged offenses were alleged to have been perpetrated upon J.G.C...from December 8 to 17, 2001. Following a jury trial...Van was convicted and sentenced on each of the five counts. He perfected this timely direct appeal... In September 2001, J.G.C. responded to an Internet advertisement posted by Van...At the beginning of this correspondence, J.G.C. informed Van that he wanted to become a total slave. Over the course of the correspondence, this relationship was defined and understood by both parties to be without limits, to have no safe word, and to be permanent. J.G.C. testified at trial that a submissive cannot end a 'no limits' relationship and that he expected to be tortured, humiliated, and to eventually die as a result of his relationship with Van. Specific punishments were discussed in the e-mail correspondence...He mentioned his fantasies about being restrained and raped...[and] specifically told Van that he may try to escape, but that Van should never allow him to do so...In various e-mail messages...J.G.C. indicated that he wanted to be flogged, whipped, beaten, restrained, gagged, shaved, tattooed, pierced, blindfolded, injected with saline, and 
locked in a cell. He also asked that hot wax be dripped on him, that clothespins be placed on his body and ripped off, and that electronic stimulation be used on him. J.G.C. wrote to Van: 'The "rules" shouldn't apply to true Masters...'...[On a subsequent day] Van... gave J.G.C. a notebook and pen, and instructed him to write down everything he had done wrong... J.G.C. testified that as he worked on this writing assignment, he began to realize that he was not a bad person...and did not need to be punished.... J.G.C. testified that at this point, he decided to end the relationship... When Van came into the dungeon room..., J.G.C. informed him that he had made a mistake and no longer wished to continue their relationship...." [Author's note: The Nebraska Supreme Court affirmed the judgment of the district court.]

"Drifter pleads guilty to killing kink shrink." Nancie L. Katz. New York Daily News, November 22, 2003, http://www.nydailynews.com/archives/ news/drifter-pleads-guilty-killing-kink-shrink-article-1.667348. "An escapee from...prison pleaded guilty to murder...admitting on tape he slit the throat of a Brooklyn psychologist after a kinky sex session went awry. [Defendant], 23,...said he met [Defenant2]...[in] Tomkins Square Park...Broke and high, he went to [Victim's] home after [Defendant2] asked him if he 'wanted to make some money.'... [Defendant] said the two tied [Victim] to a weightlifting bench with telephone wire...'He was in a sexual state of mind, and we were playing along with it,' [Defendant] said. But the pair got angry when a laughing [Victim] admitted he had urinated in the food...[Defendant2]...slammed [Victim] on the head with a pan. The men demanded money, and [Victim] gave them $\$ 1400$, [Defendant] said. 'I was like, "Let's go,"' [Defendant] said, but [Defendant2] responded, "'He's going to rat on us. You got to kill him..." I picked his head up, and I cut his throat..."”

"Man Says Sex Partner's Death Was Just 'a Terrible Accident." Lisa Donovan. St. Paul Pioneer Press, November 19, 2002. "[Defendant] says he is very good at something most would consider very bad. By his own account, the St. Paul man has led thousands of men through a fantasy of torture as pleasure, a world where consenting adults participate in a risky sex game that could end in death...And what [Defendant] refers to as 'a terrible accident' at his....apartment..., homicide investigators and prosecutors are calling a bizarre crime...[The Ramsey County Attorney's Office] charged [Defendant] with second-degree manslaughter...[Defendant] posted a profile on an Internet forum, telling interested readers he was looking for adult men to play out, among other things, fantasy strangulation by hanging or asphyxiation with the use of chloroform. [Defendant] insists [the Victim's] death, likely caused by asphyxiation from chloroform, was an accident, and that his only mistake was not calling police immediately. An e-mail he reportedly wrote before [the Victim's] death, however, has concerned investigators. The note details his fascination with sexual violence, 'especially if it ended in the slow, brutal death of one or more of the men involved.' The posting invites men to contact Bailey for 'brutal games.' [Defendant] says the e-mail has been taken out of context and is sheer fantasy..." [Author's note: Following a court trial, Defendant was found guilty of second degree manslaughter.]

"Napping beau gets nailed for cuff love." Erika Maritnez. New York Post, June 8, 2002, http://nypost.com/2002/06/08/napping-beau-gets-nailed-forcuff-love/. "[Defendant] was arrested yesterday for keeping his ex-girlfriend handcuffed in his...apartment in what he claims was a case of kinky sex gone awry, police sources said. [Defendant], 37,... allegedly cuffed his unidentified on-again, offagain flame as a prelude to sex. But he fell asleep before the act was performed, 
police said. [Defendant], who was charged with unlawful imprisonment, claims the bondage was consensual. But his 33-year-old victim says it wasn't. The woman...told cops she went to hang out with [Defendant] at his...apartment...where he drank heavily while they watched television. Then, some six hours later...the couple decided to have sex. That's when the victim says [Defendant] handcuffed her ankles - after she told him she didn't want to be cuffed - and ducttaped her wrists together, police said. [Defendant] then promptly passed out. The bound victim said she tried to rouse [Defendant] several times before he finally...awoke from his drunken stupor and unlocked one side of the handcuffs, freeing one leg, police sources said. [Defendant] then passed out again. Five hours later, the woman called police. When Emergency Service cops showed up at the apartment...to remove the handcuffs, [Defendant] was still sleeping. He had no idea why he was being locked up, police sources said."

“'You Could Get Raped." Donna Foote. Newsweek, February 8 1999. "[Victim] didn't own a computer and had never been on the Web, but it didn't take her long to figure out that she was at the center of a nightmarish criminal plot. Over the next few months, [Victim] would discover that a stalker had assumed her identity in cyberspace and was posting ads on the Internet seeking men to fulfill kinky sexual desires. 'I'm into rape fantasy and gang bang fantasy too,' [Stalker] wrote in her name, one of the many lewd postings on sites...But the sadomasochistic content of the messages wasn't the most disturbing part. The mysterious stalker was giving out [Victim's] address..."

“[Victim], suspect 'talked' for weeks: Sex, torture, bondage, death were discussed." Kris Antonelli, Scott Higham \& Debbie Price. Baltimore Sun, November 1, 1996, http://articles.baltimoresun.com/1996-11-01/news/1996306055 _1_lopatka-glass-barlow. “...But when she talked about sex, torture, bondage and death and began role-playing about strange sexual acts, she slipped into a different identity, a law enforcement source said... Investigators say the messages between [Defendant and Victim] became increasingly sexual and violent, and they believe [Victim] took an Amtrak train to North Carolina to be sexually tortured and killed. [Victim] left a note for her husband. 'If my body is never retrieved,' she told him, 'don't worry.' But her body was retrieved...in a $31 / 2$-foot deep hole about 70 feet from [Defendant's] run-down trailer...[The] associate chief medical examiner...said...the autopsy did not determine how [Victim] died, but...findings were consistent with someone...asphyxiated... Investigators say the two appeared to be role-playing...'It is my understanding that they were involved in sexual intercourse, and she accidentally died,' [Defendant's] attorney Neil Beach said..." [Author's note: Defendant pleaded guilty to voluntary manslaughter.]

“Gay Activists: Beware S\&M Predator." Chris Erikson. Manhattan Spirit, June 7, 1996. "Gay activists are warning men who frequent S\&M clubs to beware a predator...Typically, the offender...has met his victims in West Village S\&M clubs...Described as initially kind and gentle, he invites them to his home under the pretense of engaging in consensual S\&M activities. But as soon as he has them restrained - often in handcuffs suspended from the ceiling - his manner changes and a nightmarish situation ensues...Victims have reported being burned with cigarettes, beaten, bound with duct tape, suffocated, pierced, given alcohol enemas, and otherwise tortured. They have been held there for up to three days...'These are brutal assaults,' said...the president of the Manhattan-based Gay Male S\&M Activists... Upon setting his victims free, the attacker 'threatens to ruin their lives' if they go to the police...To date, none have..." 
"Rough sex killer sentenced to 25 years in prison." Mike Pearl \& Cathy Burke. New York Post, December 13, 1994. “...It will be the strong and continuing recommendation of this court that he not be paroled at any point, said [Judge] in handing down the sentence of $81 / 2$ to 25 years for manslaughter. 'He put his hands around her throat and strangled her for two long minutes,' said prosecutor...Last month, a jury convicted [Defendant] of first-degree manslaughter, accepting enough of his 'rough sex' defense to reject a verdict of murder. Defense lawyer Franklyn Gould - who claimed [Defendant] had chocked [the victim] to increase her sexual pleasure - argued for leniency. 'At most he was a whining, love sick man,' Gould said."

"Man Enters Guilty Plea in Death of Teacher...." Stephanie Grace. Philadelphia Inquirer, May 6, 1994, http://articles.philly.com/1994-05-06/news/ 25830356_1_manslaughter-charge-guilty-plea-teacher. "[Defendant] pleaded guilty...to accidentally strangling [Victim]...during consensual sex, stuffing him in an attic crawl space, stealing his car and leaving him for dead...Both the autopsy and [Defendant's] statement showed that [Victim] had been voluntarily strangled and that he was still alive when [Defendant] left the house...James J. Gerrow, executive assistant prosecutor, opened yesterday's hearing by explaining the controversial manslaughter charge...'We're dealing with what started out as a consensual encounter and...ended in death,'... but one that could have been foreseen or prevented, he said. The fatal act itself, commonly known as sexual asphyxia or oxygen deprivation, involves tying a noose around one partner's neck in order to cut off the supply of oxygen - an act some believe can heighten sexual pleasure.... When it was his turn to speak, [Defendant], 19, told Superior Court Judge...that he met [Victim], a popular 43-year-old...[high school and middle school] teacher...in the early morning hours...'He approached me in one of the booths in the porn shop...,' [Defendant] said in a barely audible voice. 'He approached me and he made me an offer for oral sex.' He said [Victim] suggested that they go back to his nearby cottage, and once there, [Victim] pulled out a noose made of rope and covered in black cloth, placed it around his own neck and asked [Defendant] to pull.”

"Women and Children's Accounts of the Harms of Pornography." Against Pornography. "I experienced from 1987 to 1989 in a two-year relationship with my batterer - From the very beginning, I was forced to provide videos for him. He found one particular one very appealing. It was of sadomasochism. He spent hours watching this movie and he then started forcing me to do the things...in this movie. One night, I spent an evening with him. I had hot wax dripped on me. A couple of weeks later, I was forced to pierce my nipples, I was forced to have sex with other people, it didn't make any difference - men, women, groups. He had me playing watersports games, which is drinking urine. And every time I said no, he would find a way of beating me...He had knives at my throat; he tried strangling me on occasion...At the end of the relationship, one of the things he wanted most was my death...He did what was in these movies...He took things straight out of the movies and used them on me..." (MacKinnon \& Dworkin, 1997).

“Crispo Cleared of Kidnapping and Sex-Torture," New York Times, October 17, 1988, http://www.nytimes.com/1988/10/17/nyregion/crispo-cleared-ofkidnapping-and-sex-torture.html. "The art dealer Andrew Crispo was acquitted...of charges that he kidnapped a homosexual man and tortured and humiliated him for six hours...His accuser, [alleged Victim], 28...said Mr. Crispo and four young men imprisoned and brutalized him in Mr. Crispo's gallery...Mr. Crispo's lawyer...noted that [alleged Victim]...admitted he liked getting hit and feeling 'a 
little pain' during sex. He said [alleged Victim] had asked for the treatment he received...[Alleged Victim] testified that in his first encounter...he...let Mr. Crispo beat him with a belt. He said Mr. Crispo then invited him to his gallery...He said that he had expected some 'rough' sex but...did not consent to six hours of torture."

Attorney General's Commission on Pornography: Final Report (1986), Part 4, Chapter 1 ["Victimization"], Subsection II.A.3. ["Battery, Torture"], http://www.porn-report.com/battery-torture.htm. "Women who were asked in a research project if they had ever been upset by anyone trying to get them to do what they'd seen in pornograph[y] described experiences similar to those reported by Commission witnesses: Miss P: My boyfriend and I saw a movie in which there was masochism. After that he wanted to gag me and tie me up. He was stoned, I was not. I was really shocked at his behavior. I was nervous and uptight. He literally tried to force me, after gagging me first. He snuck up behind me with a scarf. He was hurting me with it, and I started getting upset. Then I realized it wasn't a joke. He grabbed me and shook me by my shoulders and brought out some ropes, and told me to relax, and that I would enjoy it. Then he started putting me down about my feelings about sex...I started crying and struggling with him, got loose, and kicked him in the testicles, which forced him down on the couch. I ran out of the house. Next day he called and apologized, but that was the end of him.

\title{
"CONSENSUAL" SADOMASOCHISM GONE AWRY: CHILD VICTIMS
}

\begin{abstract}
"Boner Garage' posts a window into the world of sexualised young women online." Rohan Smith. news.com.au, June 2, 2015, http://www.news. com.au/lifestyle/relationships/boner-garage-posts-a-window-into-the-world-ofsexualised-young-women-online/story-fnet0gt3-1227378480882. "Experts say teenage girls are copying what they see in pornography and seeking treatment from family doctors for injuries sustained during 'rough sex.' They believe it's part of the dark side of the sexualisation of the internet generation...Susan McLean, a federal government cyber-safety adviser, told The Australian...'I've had GPs tell me about the injuries they are seeing in young girls when they have been forced or coerced to do what is in porn videos,' she said. 'They're not watching anything within a circle of normality - they're looking at rape, bondage, torture and bestiality. The girls in the videos all appear to like it, so girls think that's just how sex is.'... According to Reality and Risk, more than 90[\%] of boys and 60[\%] of girls have watched pornography online. Of those videos, more than 88[\%] include physical aggression...Dr Meagan Tyler, a research fellow at RMIT University, told news.com.au...' We also know that porn from the mid-to-late 1990s has become a lot more hardcore. We're seeing the mainstreaming of choking, which a lot of young women complain about."”
\end{abstract}

“30-Year Sentence in Slaying of Student." Jamie Stockwell. Washington Post, August 10, 2006, http://www.washingtonpost.com/wp-dyn/content/article/2006/08/09/AR2006080901486.html. “...[Defendant] entered a plea in the murder of 17-year-old [Victim], just eight days before his trial was scheduled to begin...[Victim's] mostly naked and decomposing body was found a month after she was reported missing, buried in a shallow ravine off a winding country road. [Defendant], 39, has repeatedly said that [Victim] died during a consensual sex act in which he restricted her breathing. But standing in the crowded courtroom, 
[Defendant] entered an Alford plea to second-degree murder. In doing so, [Defendant] did not admit his guilt but conceded that the state had enough evidence to convict him in [Victim's] killing...Under the terms of the agreement, 22 counts of unrelated child pornography charges...will be dropped...[Defendant] was romantically involved with [Victim] before she enrolled at VCU."

“Teen-strangle angle - Killer: It was an accident." Dan Mangan. New York Post, February 22, 2002, http://nypost.com/2002/05/22/teen-strangle-anglekiller-it-was-an-accident/. "The confessed killer of [a] schoolgirl...claims her strangulation death was an accident during rough sex - the same defense 'Preppy Killer' Robert Chambers used... [Defendant] and the pretty Catholic school sixthgrader met online and had sex several times before the weekend tragedy...The 25year-old [Defendant] allegedly told cops the death of 13-year-old... cheerleader...happened accidentally while they had sex in his car...'[I]t was likely a fetish [strangulation] for him,' the DOJ source said. 'He may argue there were extenuating circumstances and she consented - but, then again, she's 13 and can't by law consent'...E-mail exchanges between the girl and [Defendant] were alarmingly graphic, detectives said.” [Author's note: Defendant pleaded guilty to manslaughter and sexual assault charges.]

“'Rough sex' slay verdict: Guilty but....” Michael Hanrahan. New York Daily News, April 30, 1988. "Obviously buying his defense that he killed [Victim] during 'rough sex,' the...jury convicted [Defendant]...of the softest of four rapes - criminally negligent homicide...'This verdict is a travesty,' said the prosecutor...[Defendant] confessed to slaying [her], but a week before the trial changed his story and said the teen died accidentally when a rope she insisted he put around her neck to heighten sexual pleasure tightened during climax. [The prosecutor] noted caustically that [the crime] occurred during the time that Robert Chambers - who claimed he killed Jennifer Levin during rough sex - was being sentenced. 'Rough sex will definitely become the defense of vogue...,' he said." [Author's note: The Defendant and his female victim were reportedly high school sweethearts and were both 17 when the crime occurred.]

\section{SADOMASOCHISM: IMPACT ON MARRIAGES}

“In Cannibal Case, Officer's Wife Testifies about a Chilling Discovery." Benjamin Weiser. New York Times, February 25, 2013, http://www.nytimes.com/ 2013/02/26/nyregion/gilberto-valles-wife-testifies-as-trial-starts-in-cannibalcase.html?_r=0. “...[T] he wife of a New York City police officer opened her laptop computer and discovered that her husband had used it to visit a fetish Web site on the Internet. She said she went to the site and saw a photograph of a dead girl...The wife...said that when she later delved into her husband's electronic chat history, she found he had been communicating with others about plans to torture and kill women, including herself. 'I was going to be tied up by my feet and my throat slit, and they would have fun watching the blood gush out of me,' she said, sobbing repeatedly...The officer, [Defendant], has been charged with plotting on the Internet to kidnap, rape, kill and cannibalize female victims. His wife was the first witness in the trial...[The wife]...indicated that she had been so afraid...that she flew to stay with her parents...She said she contacted the Federal Bureau of Investigation... In addition to her testimony about discovering her husband's communications about killing her, [the Wife], 27, also described his chats with others about harming women they knew. Two were supposed to be 'raped in front of each other to heighten' their fears, she said. Another was to be burned alive, she said. There 
was also talk about putting women on a spit, and cooking them for 30-minute shifts, so they could be tortured longer." [Author's note: A federal District Court jury convicted Defendant of conspiring to kidnap women, then cook, kill and eat them, but the judge overturned the conviction, reasoning that, “...it is more likely than not the case that all of [Defendant's] Internet communications about kidnapping are fantasy roleplay.” The U.S. Attorney for the Southern District of New York has appealed the judge's ruling.]

“Charity worker...became 'slave master' to his wife and beat her with a belt after pair made sadomasochistic pact to save their 15 -year marriage." Daily Mail (UK), June 4, 2012, http://www.dailymail.co.uk/news/ article-2154515/Charity-worker-44-slave-master-wife-beat-belt-pair-sadomasochistic-pact-save-15-year-marriage.html. "A charity director inflicted a string of violent beatings on his wife after becoming her 'slave master' in a sadomasochistic pact. [Defendant], 44, lashed [Victim] with a belt when she 'broke the rules' of their bizarre sex agreement, which they had entered into in a bid to save their 15-year marriage. He faces jail after he admitted threatening her with violence, inducing her to remove her clothes, slapping her on the face, striking her on the body with a belt, seizing her by the hair and slapping her. [Defendant] pleaded guilty at Edinburgh Sheriff Court last week to a charge of assaulting [Victim], 46, on June 10 last year. [Victim] went to police after suffering three beatings on the same day...leaving her needing hospital treatment. A court heard both [Defendant] and his wife had signed a copy of a contract, which contained rules for the couple's master and slave relationship, specifying sexual acts and household chores...She faced 'punishment' if she failed to comply. In mitigation, it was said the couple had an 'unusual relationship'..."

“The guy behind the mask." Jamie Schram. New York Post, February 12, 2008, http://nypost.com/2008/02/12/the-guy-behind-mask/. "The kinky club goer who almost choked to death at a Midtown masochism mecca is a married, retired math professor..., The Post has learned. [Victim], 67, who was rushed unconscious to St. Vincent's Hospital, awoke from his ordeal...and identified himself to cops...His wife, who declined to give her first name, said, 'I thank God that my husband is still alive.' She asked a reporter to tell her the full story, and when it was finished, she said, 'Oh, my gosh, I can't believe this.'...The ex-prof, whose hands were bound behind him, had a leather collar around his neck that was attached to a rope secured to a hook on the ceiling. He was wearing nipple clamps, and his feet were in women's high heels. Cops said Benjamin began choking when one of his feet slipped out of the tall shoe...Sources said [Victim's]...fetish was to have himself trussed up and left alone."

“Deputy: Husband films wife's torture." Associated Press. Gainesville Sun, January 17, 2007, http://www.gainesville.com/article/20070117/LOCAL/ 701170326. "A man kidnapped his wife, raped and tortured her and then hung her from a tree to film a two-hour bondage porn video, authorities said...The 30-yearold man was charged with aggravated assault and battery, sexual battery, kidnapping and false imprisonment...Brevard County Sheriff's Deputy Marlon Buggs said[,] 'The attack may not have caused a death or serious injury, but the victim will be mentally scarred. He humiliated her.'...The couple went on a canoe trip down a canal...and pulled ashore near some trees. The man began raping the woman and then got a video camera to tape the act, Buggs said. He tied her to a nearby tree, where she hung naked for several hours, her toes grazing the ground, Buggs said. He struck her breasts with the side of the blade of a hunting knife, 
leaving bruises. He then raped her again, Buggs said. A computer printout describing the crime in detail was found at the scene, Buggs said. "It looked as though the suspect was following in real life what was depicted on the printout,' Buggs said.”

"Husband guilty of latex murder bid." Richard Savill. Telegraph (UK), October 17, 2006, http://www.telegraph.co.uk/news/uknews/1531609/Husbandguilty-of-latex-murder-bid.html. "A spurned husband who met his wife through an internet chatroom for sadomasochists was convicted yesterday of attempting to murder her...[The] Court heard he was furious that she had set up home with a new boyfriend, breaching the terms of a 'master-slave contract' they had signed...The court heard that [Defendant] met [Wife] through an internet chatroom devoted to fetishes including bondage and domination. He married [Wife]..., having signed the agreement that he was her master and she was his slave. He was entitled to whip her as a 'punishment', the court heard, and he bought her a collar to symbolise the relationship. The relationship often boiled over into violence and they separated after two months."

Dexter v. Dexter, No. 2005 DR 0110 (Ct. Com. Pl. Portage County, Ohio May $1,2006)$. "[Mother] testified that she is a devotee of sadomasochism; that she is bisexual; that she engages in paganism; that she has used illicit drugs on a semiregular basis; and that she spends a great deal of time online where she has two to four websites of so-called 'blogs.' The evidence also indicates that her fiancé ... also engages in sadomasochism, and in the past produced and starred in a theater troupe depicting such activity while also engaging in such conduct in his private life with [mother]....[M]other and her boyfriend have a perfect right to engage in sadomasochism, paganism and their chosen sexual orientation, but nevertheless, this Court is not convinced that [they] would exercise the due diligence that is required to engage in those practices without exposing such lifestyle to the parties' child [and thus] adversely affect[ing] the best interests of [the child, a 4-year-old girl]." [Author's note: With qualification, the trial court's judgment was upheld on appeal. The appellate court decision is published at http://www.sconet.state.oh.us/rod/docs/pdf/11/2007/2007-ohio-2568.pdf.]

"Bluff's man denies wife's claims: The jury will begin deliberating today in the kidnapping and domestic abuse case." Jennifer Greff. Omaha World Herald (Archive), March 21, 2006. "A fixation with sex, 99,000 pornographic images...were a part of [Defendant's] life...[Defendant] is accused of tying up his wife and sexually assaulting her. His trial for kidnapping and domestic abuse concluded Thursday...Thursday's testimony, laced with pornographic imagery and sexual language, depicted a man fixated on a certain sex act that he wanted his wife to perform...He admitted to buying a rope and tying it to the corners of their bed before his wife arrived home. He asked her if he could tie her up, he said, but she said no...In closing arguments, [County Attorney] emphasized that [Defendant's] wife said no, and [Defendant] committed a certain sexual act with her anyway." [Author's note: Defendant was convicted of third-degree sexual abuse but not of kidnapping because there was no evidence he had tied up his wife.]

"Sadomasochism ruled grounds for divorce in Italy." Sunday Telegraph (UK), June 24, 2002, http://www.telegraph.co.uk/news/worldnews/europe/italy/1398166/Sadomasochism-ruled-grounds-for-divorce-in-Italy.html. "Italy's highest court has ruled that sadomasochistic sexual requests can constitute grounds for divorce... The case concerns [Wife], who claims that her marriage broke down as a result of sexual demands from her husband...'which were 
sadomasochistic in nature and as such quite impossible to fulfil.'...[T]he court made the unprecedented decision that 'sexual deviancy' in a spouse was good grounds for leaving them. 'The sadomasochistic requests from [Husband] psychologically destroyed his wife, leaving her the victim of obsessions and insecurities,' ruled the court..."

"Relational Patterns Associated with Sexual Sadism: A Study of 20 Wives and Girlfriends." Janet I. Warren, \& Robert R. Hazelwood. J Fam Violence, March 2002, 17(1):75-89, http://link.springer.com/article/10.1023\% 2FA \%3A1013661007211. "Abstract: This study is derived from in-depth interviews with 20 wives or girlfriends of sexually sadistic males...These women report early life experiences that were characterized by physical abuse and incestuous relationships...However, they attained relatively stable and normal lifestyles before meeting and becoming involved with a sexually sadistic male. Once immersed in a relationship with these sadistic men, the lives of these women changed radically and, in some instances, they voluntarily entered into dangerous forms of sexuality and criminal behavior. In describing these experiences, the authors highlight the relational context of these behaviors in which the sadistic fantasy of the male becomes an organizing principal in the behavior of the woman..."

"Ex-wife recants lurid sex-slave tale." Manny Garcia. Miami Herald, December 28, 1995. "Two years ago, [Ex-wife] hysterically told police that her once loving husband had turned her into a sex slave...[Defendant], 32, is serving eight years in prison for his fetish. On Wednesday, [Ex-wife] testified that she framed her husband because she feared losing her two children in a custody fight. 'I enjoyed it,' she said of her video performances. [Ex-wife] also provided prosecutors with a 92page recantation that reads like a porno novel...There are repeated references to masking tape, bondage..., a German Shepherd and an Akita...Their films focused on bestiality, sadomasochism and other encounters...[Ex-wife] said the couple had a healthy sex life, but outside the bedroom everything collapsed. She wanted a divorce....and custody of her children... She said [Defendant] threatened to use the videos against her in divorce court. 'No one will believe you're a good mother with your references,' she quoted [Defendant].”

“Woman Gets Probation for Making Torture Films.” Judy Pasternak. Los Angeles Times, June 21, 1989, http://articles.latimes.com/print/1989-06-21/local/me-2490_1_films-mistress-anne-murray-michael-guarino. "A Hesperia woman who produced and distributed films in which she tortured her husband pleaded guilty...in Los Angeles Municipal Court to five misdemeanor obscenity counts...[Defendant] sold her hour long films for $\$ 100$ apiece through the mail, said Deputy City Atty. Michael Guarino, acting as a special assistant to the U.S. attorney. Search warrants have been served on two New York companies that allegedly also distributed [her] movies and federal charges against the firms are being considered, Guarino said... Most of the movies feature [Defendant], who stands 6 feet tall and weighs 170 pounds, inflicting punishment by various methods, some scatological, upon her 5-foot-9, 160-pound husband..."

"Wisconsin man gets life plus 164 years in torture-slaying case." Associated Press. May 23, 1989, http://www.apnewsarchive.com/1989/WisconsinMan-Gets-Life-Plus-164-Years-In-Torture-Slaying-Case/id-64b0d80a3bbba5500 37f10fd58f2eaab. "A man convicted of torturing and murdering his sister-in-law and trying to kill his wife should spend the rest of his life behind bars, said the judge who sentenced him...[Defendant], 25,...was charged with 18 counts in the 
1986 killing of his wife's sister...and the attempted murder of his 22-year-old wife...He pleaded guilty to nine charges, including the kidnapping and first-degree murder of [sister-in-law] and the attempted murder of his wife, but pleaded innocent to charges of sexual assault and mutilation. A jury convicted him of the sexual assault and mutilation charges..." [Author's note: State and Federal courts upheld Defendant's conviction. The court transcript includes this description of the assault on Defendant's wife: On September 3, 1988...the defendant induced his wife, Emily, to take a ride with him, representing that he had a 'surprise' for her. After a short drive, the defendant stopped the car at his parents' vacant farm property. He asked Emily to turn her head and look out the window, which she did. The defendant then held a knife to her throat and proceeded to commit a variety of offenses against Emily, including taping her eyes and mouth shut, taping her hands so they were bound behind her back, beating her with his fists and a metal shovel, cutting her breast and legs with a knife, burning her with a lighted cigar on the body and in her vagina, and repeatedly sexually assaulting her with a wheelbarrow handle. Emily lapsed into unconsciousness...

"Woman's death called bondage accident." Mary E. Choliet. St. Louis Post Dispatch, May 29, 1987. "[The Victim] died accidentally during a night of sexual bondage with her husband...that she herself 'orchestrated and directed,' [Defendant's] attorney argued...But [the prosecutor] argued that [Defendant] had...murdered her coldly for her money...[Victim's] nude body was found gagged and strapped to a chair in the garage, which had been set on fire...In opening arguments, [Defendant's attorney] told the jury that [Victim] had a history of mental problems and that she had been deeply involved in 'unusual sexual activity' long before she married [Defendant]...'[She] was sexually promiscuous...she engaged in sexual bondage...she orchestrated and directed the entire activity." [Author's note: Defendant was convicted of involuntary manslaughter, arson and tampering.]

Attorney General's Commission on Pornography: Final Report (1986), Part 4, Chapter 1 ["Victimization"], Subsection II.A.3. ["Battery, Torture"], http://www.porn-report.com/battery-torture.htm. “...The Commission also had received accounts from individuals who described the use of pornography in the course of physical abuse, and who attributed the type and forms of abuse to specific...materials.

A woman wrote:

... Amongst these charges would be sexual deviance due to repeated inflictions of sadomasochistic acts. I was also told I would be entitled to an annulment as the marriage remained unconsummated throughout...While doing household chores, I found very pornographic materials which illustrated sadist techniques and answered my questions as to where my husband got these bizarre ideas.

A women's shelter wrote to the Commission:

One woman known to us related that her spouse always had a number of pornographic magazines around the house. The final episode that resulted in ending their marriage was his acting out a scene from one of the magazines. She was forcibly stripped, bound and gagged. And with help from her husband, she was raped by a German shepherd. [Pornographic magazines] were always a part of the literature in the third woman's home...His 
favorite form of abuse was bondage. He enjoyed playing what he called a 'game' of whipping and slavery. She knows that what he did to her was directly related to articles about bondage and sex [slaves] which he read.... He wanted to involve a second woman, her friend, in the scenarios.

A mother of two girls testified:

[My husband] had a large collection of bizarre S\&M and bondage pornography that he kept in the nightstand drawer in our bedroom. On one occasion [he] tied me to our bed and sodomized me. This occurred after I refused to agree to be bound and tied as the models appeared in some of [his] pornographic magazines. Also, the girls told me that [he] sometimes played a game with them in which their feet were tied up tightly with a rope. The molestation included 'bad touching' and exhibitionism by [him], but did not involve actual penetration.

"Women and Children's Accounts of the Harms of Pornography," Against Pornography. "I married this man, and for the next two years we mainly pursued our careers. During the second year of our marriage, he started reading more and more pornography. He started out reading Playboy and started picking up magazines like Penthouse and Forum, and as I would... come home from work and fix dinner he would read me excerpts from the magazines...I was really repulsed at the things he was reading me...He bought more and more of magazines...I agreed with him to act out in privacy a lot of those scenarios that he read to me, a lot of them depicting bondage and different sexual acts that I found very humiliating...I could see how I was being seasoned by the use of pornography and I could see what would come next. I could see more violence and I could see more humiliation, and I knew at that point I was either going to die from it, I was going to kill myself, or I was going to leave... He would read from pornography like a textbook, like a journal. In fact, when he asked me to be bound, when he finally convinced me to do it, he read in a magazine how to tie the knots and how to bind me in a way that I couldn't get out. And most of the scenes...were the exact scenes that he had read in the magazines..." (MacKinnon \& Dworkin, 1983; reprinted in MacKinnon \& Dworkin (1997)).

\section{SADOMASOCHISM: IMPACT ON CAREERS}

“50 Shades principal' showed penis pics to her underlings: suit.” Selim Algar \& Aaron Short. New York Post, April 13, 2015, http://nypost. com/2015/04/13/50-shades-principal-showed-penis-pics-to-her-underlings suit/. "The principal at a...public school blabbed about 50 Shades of Gray showed off tattoos and piercings and revealed graphic details of her sex life in front of a disgusted underling, a new Brooklyn federal court lawsuit charges. [Alleged Victim] claims that his boss, Principal [name omitted], battered him with unwelcome sex talk that was part of a larger campaign of discrimination..., according to the suit. [Alleged Victim] was promoted...to assistant principal...where he worked directly under [Principal], the suit states. His boss immediately began peppering him and other staffers with unsolicited discussions of her sexual liaisons and tastes, the suit claims. '[Principal] discussed the book Twelve Shades of Gray the suit states, misstating the title of the steamy novel turned hit movie. 'During administrative meetings she passed her phone around showing pictures of male penises.' [Alleged 
Victim] claims she would walk around him with her pants open and made sexually suggestive movements in front of him, the suit states...'She also lifted her shirt to show her tattoos and what [Victim] believed to be a piercing of her belly button."”

“...CBC Radio Host...Fired in Sex Case." Ian Austen. New York Times, October 27, 2014, http://www.nytimes.com/2014/10/28/business/media/jian ghomeshi-cbc-radio-host-is-fired-in-sex-case.html?_r=0. "When the radio personality [Defendant] suddenly announced on Friday that he was taking a leave of absence from his popular show, many Canadians assumed it was related to the recent death of his father...In a brief statement on Sunday, the Canadian Broadcasting Corporation announced that it had simply cut ties with [Defendant]. He quickly followed up that evening with a 1,500-word Facebook post, detailing his side of the story. In the post, [Defendant] said that CBC had fired him over the concerns that consensual sexual acts, that he described as "a mild form of Fifty Shades of Grey," were about to become public. Later Sunday, The Toronto Star reported that three young women had said [Defendant] had been 'physically violent to them without their consent during sexual encounters or in the lead-up to sexual encounters.' The newspaper said that the radio host 'struck them with a closed fist or open hand; bit them; choked them until they almost passed out; covered their nose and mouth so that they had difficulty breathing; and that they were verbally abused during and after sex."”

"Mental health counselor flogged me, introduced me to sadomasochism says Pasco woman." Mark Douglas. WBTW News, May 21, 2014, http://www.wbtw.com/story/25583149/mental-health-counselor-flogged-me-introduced-me-to-sadomasochism-says-pasco-woman. “...[A] Pasco County woman we will call Mary Jane was coping with the loss of a child and sought help from licensed mental health counselor [LMHC]... But instead of relieving her pain, Mary Jane told 8 on Your Side, [LMHC] quite literally inflicted it after taking her as his lover and introducing her into a sadomasochistic lifestyle she had never known...[LMHC] somehow convinced Mary Jane that having this sexual relationship would help her, public records show. 'The way I could heal from being molested as a child was to engage in a sexual relationship with him,' she told 8 on Your Side. Florida law makes it a crime for mental health counselors to have sex with clients. The Florida Department of Health, which licenses counselors, calls it 'sexual misconduct,'...A Florida Department of Health complaint in 2012 formally accused [LMHC] of committing acts of sexual misconduct...including flogging. She claims he...beat her with a whip, and practiced other forms of domination while she served....as his 'submissive' or sex slave...[LMHC] officially surrendered his license at a Tampa meeting of the State of Florida Board of Clinical Social Work, Marriage \& Family Therapy, \& Mental Health Counseling. As part of his agreement with the DOH, [LMHC] 'does not admit any wrongdoing whatsoever.' But he had to give up his right to practice in mental health counseling in Florida.”

"Manhattan AG's office suspends lawyer who moonlights as a dominatrix." Jamie Schram. New York Post, September 17, 2011, http://nypost .com/2011/09/17/manhattan-ags-office-suspends-lawyer-who-moonlights-as-adominatrix/. "A well-respected lawyer in the state Attorney General's Office spends her days toiling in securities fraud - and her nights moonlighting as a dominatrix, The Post has learned. [Lawyer], 36, who dresses demurely as a buttoneddown prosecutor, turns up the heat when she becomes perky persecutor... when she performs at S\&M events for pay, according to a fetish source. 'They pay her to go to the events. She dominates people, restrains them and whips them,' the fetish 
source said...Now [Lawyer] is on the receiving end of some serious discipline from her bosses at the AG's office. Yesterday, she was removed from her duties...Sources familiar with the issue say [Lawyer's] punishment has less to do with her personal pleasure and more to do with the possibility that she profited from it." The Assistant Attorney General later quit her job but "denied that she was ever paid for performing as a dominatrix at S\&M parties” (CBS News, 2011, October 17).

"Sexual kinks not a factor in denied limo permit." Bethany Lindsay. CTV News Vancouver, November 24, 2010, http://bc.ctvnews.ca/sexual-kinks-not-afactor-in-denied-limo-permit-1.578280. "A Vancouver man's enthusiasm for bondage and his pagan beliefs were not the reason he was denied a permit to drive a limousine, the B.C. Human Rights Tribunal has ruled. [Alleged Victim] had alleged that the Vancouver Police Board...denied him a chauffeur's permit because of his religion and sexual orientation...According to tribunal documents, [Alleged Victim] says that he is a practicing Pagan and that his sexual orientation is BDSM - a term for people who practice bondage and discipline, dominance and submission, and sadism and masochism... [Alleged Victim] arrived at the interview dressed all in black...When...asked what the occasion was for all the black, [Alleged Victim] testified that he said he always wore black, like many Pagans...[Alleged Victim] testified before the Tribunal that the officer called him a 'sex cult leader' during the interview, and was refusing the permit because of that...But [Officer] told the tribunal that he denied the permit after a background check revealed a series of troubling allegations against [Alleged Victim] spanning 10 years...Vancouver police denied...his permit, "because they believed, perhaps wrongly, that he was "unfit to act as a chauffeur," because he presented an unacceptable risk of inflicting violence, practicing coercion or behaving inappropriately with those with whom he would necessarily come in contact in the course of his work,' [Tribunal member] wrote...But the tribunal's decision this week did not include a ruling on whether BDSM can be considered a sexual orientation under the Human Rights Code."

“Anti-bias crusader had 'kink' in armor." Dan Mangan. New York Post, June 5, 2008, http://nypost.com/2008/06/04/anti-bias-crusader-has-kink-in-armor/. "A leading...women's rights lawyer watched porn at his desk, discussed his 'pierced genitalia' and wears a 'slave' collar at work as part of a sadomasochistic relationship with his girlfriend, a shocking sex-harassment suit alleges...[The lawyer], whose law firm says it's 'dedicated to the empowerment of women in the workplace,' is a 'self-described "testosterone-poisoned" attorney with a penchant for bondage'... says the suit. It was filed today...by [a] former office manager...The exmanager claims [the lawyer] revealed he met his girlfriend...on an S\&M Web site. He had a computer screensaver that included a photo of [the girlfriend] dressed as a dominatrix with [him] dressed in black and kneeling at her feet."

“Charity exec 'stole' for S\&M gal.” Larry Celona. New York Post, December 12, 2005, http://nypost.com/2005/12/01/spanky-panky-loot-charity-exec-stolefor-sm-gal/. A charity executive used $\$ 210,000$ meant to cure heart disease to get his own pulse pounding - repeatedly flying a dominatrix halfway across the country to spank him, law-enforcement sources said yesterday. [The Defendant] racked up charges on an employer credit card for a slew of personal items, including steamy S\&M meet-and-beat sessions with [Dominatrix], a world-renowned whip mistress..., the sources said...The [Defendant] allegedly used the funds to fulfill his fetish fantasies by paying the...mistress' air fare to New York each month - and 
ponying up for a wardrobe full of bawdy bondage gear, including chains and whips..."

“Chamber Judgment: K.A. and A.D. v. Belgium.” Press Release. European Court of Human Rights, February 17, 2005, https://wcd.coe.int/ViewDoc.jsp?id=840593\&Site=COE. “...At the material time K.A., who was a judge, and A.D., a doctor, took part in sadomasochistic practices with the wife of K.A. Between 1990 and 1996 they frequented a sadomasochism club...[T]he Antwerp Court of Appeal found the applicants guilty of assault occasioning actual bodily harm and also found K.A. guilty of incitement to immorality or to prostitution. K.A. was sentenced to one year's imprisonment and fined 100,000 Belgian francs...those penalties being suspended and accompanied by other sanctions including disqualification from public duties, employment or office for five years... With regard to the offence of assault occasioning actual bodily harm, the Court of Appeal observed that the applicants had engaged in extremely violent practices on premises which they had specially hired and equipped for that purpose and that such practices were, moreover, forbidden by the rules of the sadomasochism clubs which K.A. and his wife had previously frequented. Besides the extreme cruelty of those practices, it appeared from video recordings seized during the investigation that the defendants had, in particular, ignored several pleas by their victim for their activities to stop.

The Court of Appeal considered that the practices in question were so serious, shocking, violent and cruel as to undermine human dignity, and the fact that the defendants continued to maintain that their activities had merely amounted to a kind of sexual experience in the context of sadomasochistic rituals played out behind closed doors between consenting adults did not alter that conclusion...The Court of Appeal also found it established that K.A. was guilty of incitement to immorality and to prostitution, seeing that he himself had suggested to the management of a sadomasochism club that his wife be employed there as a 'slave' to indulge in extremely violent practices amounting to immorality and prostitution, that he had implicitly consented to the publication of classified advertisements to that end and that for months he had provided material assistance by driving his wife to the club in question on several occasions, each time coming to collect her and receive her earnings.

The applicants appealed to the Court of Cassation, which dismissed their appeal...Observing that K.A. had seriously undermined the dignity of his office as a judge and that he was accordingly unfit to hold such office, the Court of Cassation dismissed him...He subsequently lost his entitlement to a public-sector retirement pension...The applications were lodged with the European Commission of Human Rights...and transmitted to the Court. [Author's note: The Court held that the European Convention on Human Rights had not been violated.]

U.S. v. Ragsdale, 426 F3d 765 (5th Cir. 2005), http://caselaw.findlaw. com/us-5th-circuit/1360229.html. "This appeal arises from the defendants', Garry and Tamara Ragsdale, conviction following a jury trial on one count of conspiracy in violation of 18 U.S.C. $\S 371$, and two counts of mailing obscene materials and aiding and abetting in violation of 18 U.S.C. $\S \S 1461$ and 1462. The Ragsdales appeal from their convictions and sentences. They also challenge...the constitutionality of $\S 1461$. For the reasons set forth below, we affirm... In 1998, the Dallas Police Department received a complaint...about pornography sold from [website name omitted]... Detective Doyle Furr was assigned to investigate the complaint. 
He recognized the name and address of the website owner as that of a fellow Dallas police officer...Two of the videos are alleged to be obscene...One tape...was touted as being the actual rape of a young woman. In the first half of the video, the woman seems to consensually engage in various sexual activities with as many as three different males...[T] he remaining half of the video depicts in graphic detail, among other things, her being hoisted up by her ankles upside down with chains and then being sodomized with various objects and seemingly tortured with hot wax. She is also flogged with a whip...The female and male participants then seem to taunt her while she cries. Garry was initially charged with obscenity under Texas state law..., but those charges were later dropped. After 8 years as a Dallas police officer, Garry was fired from his job for conduct unbecoming of an officer...On July 9, 1998, the [FBI], in conjunction with the Dallas Police Department and United States Postal Inspectors, obtained a search warrant...Almost five years later, in March of 2003, Tamara and Garry were each indicted...[T]he jury found them both guilty of all charges." [Author's note: Both Gary and Tamara Ragsdale were sentenced to 33 months' imprisonment.]

"Illinois Senate campaign thrown into prurient turmoil." Stephen Kinzer. New York Times, June 23, 2004, http://www.nytimes.com/2004/06/23/ us/illinois-senate-campaign-thrown-into-prurient-turmoil.html. “...According to court depositions unsealed Monday, [Name omitted], a Republican who is challenging Barack Obama, a Democratic state senator, for the seat held by [U.S.] Senator Peter G. Fitzgerald...took his wife to sex clubs in...the late 1990's. The documents suggest that [Name omitted] insisted that they have public sex but that [his wife] angrily refused, and the issue led to the breakup of their marriage...'If the allegations made were true, it would end the candidacy,' said...one of the candidates...defeated in the Republican primary...Asked about the accusations in the unsealed depositions, Mr. Obama replied: 'I don't think it's appropriate for me to comment on that. Those are issues of personal morality. The issues I'm focused on are public morality.'...[The wife]...said in a declaration...that when she and her husband were in New York...he then took her to 'a bizarre club with cages, whips and other apparatus hanging from the ceiling.' 'Respondent wanted me to have sex with him there, with another couple watching,' she said..." [Italics added]

“Torture as Pornography." Joanna Bourke. Guardian (UK), May 7, 2004, http://www.theguardian.com/world/2004/may/07/gender.uk. "A woman [at Abu Ghraib prison] ties a noose around a naked man's neck and forces him to crawl across the floor. Uniformed people strip a group of hooded men, then...assemble them into a pyramid. Men are forced to masturbate and simulate fellatio...[W]e have all participated in the pornographic gaze...These snapshots tell us more than we may perhaps want to know about our society's heart of darkness. This festival of violence is highly pornographic....The people taking the photos exult in the genitals of their victims...[T] he photographers don't even seem aware that they are recording a war crime. There is no suggestion that they are documenting anything particularly morally skewed. For the person behind the camera, the aesthetic of pornography protects them from blame. Indeed, there is a carnivalesque atmosphere to the photographs. The perpetrators of this sexual violence are clearly enjoying themselves...Furthermore, the pornography of pain as shown in these images is fundamentally voyeuristic in nature. The abuse is performed for the camera...These obscene images have a counterpart in the worst, non-consensual sadomasochistic pornography. The infliction of pain is eroticised..." [Author's note: 
Some military personnel were convicted of crimes related to the Abu Ghraib scandal; others were reprimanded.]

"Whipped from her book: Clients eyed in dominatrix slay." Michelle McPhee. New York Daily News, July 29, 1997, http://www.nydailynews.com/archives/news/whipped-book-clients-eyed-dominatrix-slay-article-1.770864. "The little black book of a dominatrix shot dead on the upper West Side contains hundreds of names all arranged in the order customers visited her lair to act out bondage fantasies, sources said yesterday. The book is detectives' best lead in determining who gunned down 58-year-old Nadia Frey in her seventh-floor flat jammed with whips, chains and porno photos. 'We're still leaning toward the customer angle,' said a source close to the investigation...Frey listed her clients without titles or organizations, sources said. While no famous names have jumped out at cops, detectives were scanning the book to see whether any celebrities or public officials used her services. Frey, known professionally as Mistress Hilda, kept a running chronological account of whom she tied up and beat inside her W. 72d St. apartment, putting phone numbers next to repeat customers...On the wall, she kept pictures of herself and her clients, said a source."

"Sex dungeon stint doesn't faze Labrador." Associated Press. Miami Herald, July 1, 1995. "The outlook seemed brighter Friday for a dog than his master who faced a variety of charges in a sexual fantasy fulfillment case authorities say involved videos, prostitutes, bondage and even a dog. Both [Defendant] and his Labrador named Blackie were behind bars. [Defendant], 48, was in the Hillsborough County jail on charges of prostitution, pornography, racketeering and animal cruelty. Blackie, 18 months, was in a cage at an animal shelter...[Defendant] was arrested... along with three women during a raid at a sex dungeon in this rural community near Tampa. Investigators said customers paid money to be videotaped, watch films of others, or engage in acts involving whips, handcuffs, slaves, and, upon occasion, the dog. [Defendant], whom police described as a pimp and pornographer known as 'Master Troy,' maintained there was nothing wrong with the activities that went on at his place...As for Blackie, he's in safer hands now." [Author's note: Defendant and one of the women case pleaded guilty to charges.]

“Rapist's wife sobs: 'He is not a monster."” Mark Pearl. New York Post, April 13, 1994. "A judge sentenced an executive to up to nine years in prison for a brutal sex attack on a co-worker, despite a plea from his wife who sobbed, 'He is not a monster.' Prosecutor Mariene Besterman called [Defendant's] attack 'four hours of depravity.'... [Defendant's] 28-year-old victim...told Justice Paul Bookson: 'In order to satisfy his fantasy, he destroyed my life.'...[Defendant], a former manager for Mitsubishi Industries in Pittsburgh..., was accused of tying up, gagging, beating, raping and sodomizing the young woman - who worked in Mitsubishi's New York office - in his...Hotel room after a night of drinking...[Defendant's lawyer] called [Defendant] a 'mainstream American,' although one who was 'drunk to the gills' on the night of the...attack."

"Ex-Hooker says [Diplomat] bought kinky sex." Esther Pessin. New York Post, October 14, 1989. "A one-time Vienna prostitute has told a grand jury [that] suspected spy [Diplomat] paid her for seven years to be 'humiliated and beaten,' ABC News reported last night. Investigators are trying to determine if the suspended U.S. diplomat's kinky sex habits drove him into the arms of the Russians, the news program said. In an interview with $\mathrm{ABC}$, the woman...claims [Diplomat], the second-ranking diplomat in Vienna at the time, visited her twice a week for 
seven years - and paid her $\$ 200$ for each sadomasochistic sex session. That amounts to at least $\$ 10,000$ a year for a diplomat earning between $\$ 60,000$ and $\$ 80,000$ a year (with free housing), ABC pointed out... Her testimony reinforced investigators' concern that he may have had similar relationships earlier in his career - and fallen into a Soviet era sex trap while stationed in other...countries."

\section{BONDAGE, RAPE, TORTURE \& MURDER}

“The Men Who Murdered." Robert K. Ressler \& Ann W. Burgess. FBI Law Enforcement Bulletin, 54(8):2-6 (August 1985), https://www.ncjrs.gov/ pdffiles1/Digitization/99114-99117NCJRS.pdf. "Statistics from the FBI's Uniform Crime Reports document the alarming number of victims of sexually violent crimes...A subsample of 36 sexual murderers was selected for analysis to develop further information for profiling these murders. Here we present what we learned about these 36 men...When looking at individual development of the offenders, two factors stand out - the dominance of fantasy and...These fantasies were primarily violent and sadistic in nature. Twenty offenders had rape fantasies before age 18, and seven of these men acted out these fantasies within a year of becoming consciously aware of them...When...asked to rank their sexual interests, the highest ranking activity was pornography (81\%), followed by masturbation (79\%)...In addition, when questioned about the murders themselves and their preparations for the murders, the men identified the importance of fantasy to the rapes and murders...Their visual interests (pornography...) reinforced the sex and aggression.”

"Life on the Street: New wave of prostitution with more violence is overwhelming Los Angeles authorities." Miles Corwin. Los Angeles Times, December 8, 1985, http://articles.latimes.com/1985-12-08/local/me-15142_1_ street-prostitutes. "...[A]bout 30 madams and call girls gathered to discuss a significant change in their business...And more customers, she said, were beating, torturing and even killing out-call prostitutes... An increasing number of customers are requesting violent or kinky sexual services..., prostitutes and call girls say...The sexual revolution has contributed to the change prostitutes have seen, said Dr. Michael Grinberg, a psychiatrist, sex therapist and chairman for the Society for the Scientific Study of Sex...There are several possible reasons for the change, [he] said. Our society is more violent... Pornography is more graphic and readily available and some of the behavior displayed 'can become incorporated in one's sexual fantasies.” [Author's note: See also, (Silbert \& Pines, 1984).]

"The Sexually Sadistic Criminal and His Offenses." Park E. Dietz, Robert R. Hazelwood \& Janet Warren. J Am Acad Psychiatry Law, 1990 June; 18(2):163178, http://www.jaapl.org/content/18/2/163.full.pdf. "This is an uncontrolled, descriptive study of 30 sexually sadistic criminals. All were men, and all intentionally tortured their victims in order to arouse themselves. Their crimes often involved careful planning, the selection of strangers as victims, approaching the victim under a pretext, participation of a partner, beating victims, restraining victims and holding them captive, sexual bondage, anal rape, forced fellatio, vaginal rape, foreign object penetration, telling victims to speak particular words in a degrading manner, murder or serial killings (most often by strangulation), concealing victims' corpses, recording offenses, and keeping personal items belonging to victims...Eighty-three percent of the men maintained collections of items related to 
sexual or violent themes or both. The most commonly occurring collection was pornography (53\%), followed in frequency by guns (37\%), bondage paraphernalia (27\%)...Smaller proportions of men collected... sexual devices (7\%)...Because this was an exploratory, uncontrolled study of a highly selected group of offenders, it would be inappropriate to draw conclusions about sexual sadists in general from the data..."

"Serial killers: Increasingly their targets are prostitutes." Joe Slobodzian. Philadelphia Inquirer, May 13, 2011, http.//www.philly.com/philly/ blogs/crime_and_punishment/Serial-killers-increasingly-their-targets-are-prostitutes.html. "It's been called a victimless crime, but...prostitution is anything but. Criminologists have long known that prostitutes are especially vulnerable to being victimized: raped, robbed, beaten and sometimes killed. Now, a new study by a professor at Indiana University Purdue University Indianapolis' School of Public and Environmental Affairs has found that the victims of serial killers are increasingly likely to be female prostitutes. In an article, 'Prostitutes as Victims of Serial Homicide,' published in April in the Sage Publications journal Homicide Studies, Kenna Quinet wrote that from 1970 through 2009 the proportion of victims of serial killers who were female prostitutes went from 16 percent to 69 percent... Quinet based her conclusions on a database created from information about 3,228 victims of 502 solved U.S. serial murder cases from 1970 through 2009...Not surprisingly, Quinet's study noted, 46 percent of prostitute killings are unsolved.”

“Murdered by porn...." Paul Bracchi. Daily Mail (UK), December 12, 2013, http://www.dailymail.co.uk/news/article-2522846/High-profile-cases-child-killers-hooked-extreme-porn-just-tip-iceberg.html. “...Not only did [Defendant] strangle [a] 17-year-old [girl]...with a ligature, he also took pictures of her 'before, during and after' the killing...They were the photographic equivalent of a 'snuff' movie. [Defendant], 23, was an enthusiastic consumer of 'snuff' movies - where women are killed during extreme sex to satisfy sick fantasies - and other kinds of hardcore pornography. Was this obscene pornography the cause of his depraved behaviour, or was it simply a consequence of it? We shall never know. What the judge was in little doubt about, however, was that the material found on his computer played a part in [the] murder...Extreme pornography is the common denominator that links the death of [names of victims omitted here]. The men...who committed these notorious murders [names of perpetrators omitted here] were all obsessed with pornography... It would be easy to assume they are just isolated examples. In fact, they're not. They are just the most high-profile; the ones we are all familiar with. Similar cases go largely unreported in courts up and down the country with alarming regularity. Not everyone who watches this filth goes on to rape or murder, but a significant minority, like the individuals featured on these pages, do...."

\section{Bondage, Rape, Torture and Murder: Adult Victims}

"[Defendant] was violent long before 7 killings." Michael Tarm \& Tom Coyne. Associated Press, KXAN, October 21, 2014, http://kxan.com/ 2014/10/21/darren-vann-was-violent-long-before-7-killing/. “...[T]here were signs years ago of increasing violence against women by [Defendant], who police said...has confessed to killing seven women [all prostitutes] in northwestern Indiana. Indiana court records from 2004 describe him grabbing a woman in a chokehold, dousing her with gasoline and threatening to set her on fire. He was 
sentenced to a year in prison. In 2009, he was convicted in Texas of raping a woman. She told police that when she went to his apartment in Austin he knocked her down and began to strangle her, hit her several times in the face and said he could kill her, court records show. He served time in prison until last year, when he was released and moved back to Indiana. In both cases, the charges against Vann were reduced as part of plea bargains...He registered as a sex offender in Indiana and police made a routine check in September that he lived at the address he provided..." In an op ed article about the murders James Alan Fox (2014) wrote that: "A sexual sadist can hunt the streets of the city or browse the online ads of Backpage, as [Defendant] reportedly did, looking selectively for the one who might best satisfy his violent fantasies."

"Attacks at University of Florida spark memories of 1990 murders." Sara Sidner. CNN, September 8, 2014, http://www.cnn.com/2014/09/08/us/sidner-florida-serial-killer-memories/. “...Unlike the most recent attempted assaults around [University of Florida] campus, the victims in 1990 didn't have a chance. For five students that year, assaults ended in dismemberment and death. The first attack happened the Sunday before school started. Gainesville police were called to check on two students in their apartment. When they arrived, the scene horrified them. Both [female Victims] had been stabbed to death, one of them mutilated, her body posed in a sexually explicit manner. Within 72 hours, five students were fatally stabbed, the crime scenes staged for dramatic effect...It happened that as a student journalist working at the university television and radio station, I ended up covering the trial. I was among those allowed to view the crime scene photos that were entered into evidence. I have never been able to get those scenes out of my head. The worst: a picture of a victim's body on a bed with her severed head staring down from a bookshelf. It is the stuff of nightmares. They were haunting, purposely theatrical photos that were pornographic in nature due to the positioning of the bodies. All of them seemed to be scenes from a horror film too gruesome to make."

"Prostitute raped, tortured, crucified in Italy; case mirrors 2013 attack." Meg Wagner. New York Daily News, May 7, 2014, http://www.nydailynews.com/news/crime/prostitute-raped-tortured-crucified-italy-article1.1783067. "Italian police are hunting for a monstrous serial attacker who raped and tortured a prostitute in Florence before 'crucifying' her naked body on a bridge. The brutal killing mirrors another attack on the same overpass last March. The 26-year-old [Romanian immigrant] had been forced to kneel with her outstretched arms taped to a horizontal barrier under the bridge..., Police said she had been sexually tortured before she was left to die, and bruising showed she struggled throughout the horrific assault, police say...Last year, another prostitute survived an identical attack in the same spot...She told police an Italian man raped her and stole her purse. She suffered devastating internal injuries during the gruesome attack and is still undergoing physical therapy. During the past 10 years, six or seven more prostitutes have been killed in the area, Florence investigator Lorenzo Bucossi told the Daily Beast."

"PBSO: Man arrested in Guatemala suspected in assault there, matched DNA for 5 rapes here." Hannah Winston. Palm Beach Post, March 27, 2014, http://www.mypalmbeachpost.com/news/news/crime-law/pbso-tospeak-today-about-serial-rapist-linked-to-/nfMH9/. “...According to the women attacked, [Defendant] raped each multiple times as well as beat them, bit some and robbed others...[Defendant]...will be charged with 10 counts of sexual battery with 
physical force...The first attack came April 9, 2009...According to the arrest report, the woman was punched and kicked and was in and out of consciousness, then raped. The third attack took place Aug. 7, 2009...[A] man grabbed her, cut her throat, bit and beat her until she was unrecognizable and raped her, investigators said...On Jan. 16, 2010 a woman...was raped while on her way to work. She was left with multiple facial fractures, head trauma and bleeding on the brain, the sheriff's office said. The final known attack was on Sept. 23, 2011...Authorities say [Defendant] beat her until she was unconscious. She told investigators at the time she woke up without pants or her belongings.”

“2 Guilty in Plot to Kidnap, Torture and Kill Women." Associated Press, New York Times, March 14, 2014, http://www.nytimes.com/2014/03/15/ nyregion/2-guilty-in-plot-to-kidnap-torture-and-killwomen.html?_r=0. "A retired New York high school librarian and a New Jersey auto mechanic were convicted Friday of scheming to carry out gruesome fantasies of kidnapping, raping, torturing and killing women and girls. The verdicts in the federal conspiracy trial of [Defendant], 61, and [Defendant2], 24, came a year after a conviction in a headline-grabbing case of a New York police officer accused of plotting abductions and cannibalism. A fourth man, a former hospital police chief, pleaded guilty...Together, the cases plumbed an online underground where people share macabre fetishes, and the prosecutions hinged on the boundaries between imagining and actually intending to bring fantasies to life. Lawyers for both men said they would appeal...'Today, a unanimous jury found that the twisted conspiracies of [Defendants] were not mere fantasy, but steps within very real plans to kidnap real victims,' Preet Bharara, the U.S. Attorney in Manhattan, said in a statement. But defense lawyers said... [Defendants] were only role-playing and would never have actually hurt anyone."

"Man faces 25 years to life for kidnapping, rape, torture." Susan Jacobson. Orlando Sentinel, February 27, 2014, http://articles.orlandosentinel.com/2014-02-27/news/os-kidnap-torture-rape-guilty-daytona-beach-

20140226_1_25-years-kidnapping-25-year-old-woman. “...It took just 20 minutes for the jury to reach a verdict in the sexual-battery and kidnapping case.[Defendant] put a knife to the 25-year-old woman's throat after she got into his truck April 11, 2011, hogtied her and told her not to scream or he would kill her, the victim testified. At his home...he hanged her from a beam, made her perform sex acts and beat her over the next 17 hours while forcing her to watch violent pornography. He also made her watch the torture by pointing a camera at her and hooking it to a computer monitor and television, prosecutors said. The woman, who told investigators she was a crack-addicted prostitute..."

“DA: Sex, Torture Case is 'Horrific, Unimaginable.'” Monica Garske \& Artie Ojeda. KNSD TV, February 3, 2014, http.//www.nbcsandiego.com/news/local/Brendan-Mathis-Sex-Assault-Torture-Case-Mission-Valley-243022001.html.

"A San Diego prosecutor revealed the extremely graphic, violent details...of two separate assaults on two women allegedly committed by a man who met his victims through online escort ads and tortured them...'This case is horrific....,' said San Diego Deputy District Attorney Mary Ellen Barrett...[Defendant] was arrested...at a Mission Valley apartment complex...San Diego police said [Defendant] went to the complex to meet with a paid escort he connected with through an online ad....[He allegedly attacked her with a taser and tried to tie her up. The 30-year-old woman managed to escape by jumping off the second-story balcony of her apartment...Lt. Chuck Kaye with the San Diego Police Department Sex Crimes Unit...also said 
[Defendant] had attacked another escort in a similar manner...However, that victim was not able to escape... When he arrived at the woman's hotel room he allegedly tased her, attacked her and forced her to the ground. 'He bound her hands and feet and said that he had an axe and he was going to kill her, and that she should just go along and cooperate,' Barrett explained...Barrett alleged that [[Defendant] then proceeded to blindfold his victim. At one point he allegedly flicked the burning amber from a cigarette at the woman's private parts. After that, Barrett said the woman was subjected to a 'four or five-hour-long' torture session that included repeated, forced oral copulation so violent that Barrett said the victim suffered injuries. The prosecutor said the alleged attacker would take short breaks between the forced oral sex acts. He then allegedly raped the woman." [Author's note: Defendant pled guilty to forcible rape and assault with intent to commit oral copulation.]

Kelly v. State, CR. 10-0642, Court of Criminal Appeals of Alabama (2014), http://caselaw.findlaw.com/al-court-of-criminal-appeals/1660426.html. "[Defendant] appeals his convictions for two counts of capital murder and one count of sexual torture. [Defendant] was convicted of one count of capital murder for taking the life of [Victim] during the course of a first-degree kidnapping...; a second count of capital murder for taking the life of [Victim] during the course of sexual abuse...; and one count of sexual torture...The circuit court accepted the jury's recommendation and sentenced [Defendant] to death. It also sentenced [Defendant] to life in prison for his sexual-torture conviction...The autopsy performed on [Victim's] body by Dr. Valerie Green indicated that she had been tortured prior to her death. She had a bruise and skin tears around her right eye consistent with being punched. She had cuts on her head and ear, a bruised lip, and multiple brain hemorrhages. Her neck was scratched and bruised and she had multiple bruises on her chest and back. Her legs and arms, including her wrists, were bruised. [Victim] had multiple cuts and bruises in her vagina. She also had multiple cuts and bruises around and in her anus and rectum, including a cut in the rectal lining located five to five and a quarter inches from the anal opening. Dr. Green testified that the injuries to [Victim's] genital area were consistent with being caused by the toilet plunger that [Defendant] had thrown away. She further determined that [Defendant] was alive when her injuries were sustained...Dr. Green determined...death was caused by asphyxia resulting from strangulation.”

\footnotetext{
"Sadistic torturer...declared dangerous offender." Sam Pazzano. Toronto Sun, December 6, 2013, http://www.edmontonexaminer.com/2013/12/06/sadistic-torturer-john-siscoe-declared-dangerous-offender. "A sadistic man who inflicted months of brutality on his captive torture victim was declared a dangerous offender and locked up indefinitely...'The atrocities are almost unspeakable,' said Justice John McMahon in imposing an indefinite sentence against [Defendant] who inflicted months of physical, psychological and sexual agony against a 32year-old disability pensioner...Earlier this year, McMahon described this case as 'one of the worst torture and abuse cases in Canada' when [Defendant's] lover was handed an eight-year sentence. She watched the horrific abuse but did nothing to stop it...[Defendant] pinned the victim's lips together, pulled cartilage out of the victim's ears and nose, inserted pins into his genitals, used hot knives to cauterize wounds as well as lighting his head, face and groin on fire, said McMahon. The victim suffered 12 to 15 occasions of violent sexual abuse. [Defendant] sodomized him with large objects and forced him to perform oral sex, court heard...[Defendant] also admitted to abusing three prior domestic partners, including raping a
} 
pregnant lover...[Defendant] said watching women suffer pleasured him. He turned one lover to prostitution to feed their cocaine addiction, court heard."

"Kidnap Survivor Michelle Knight Begged Ariel Castro Not to Abduct Others." Christian Ng (Good Morning America). ABC News, November 5, 2013, http://abcnews.go.com/US/kidnap-survivor-michelle-knight-begged-ariel-castro--bduct/story?id=20788204\&singlePage=true. "Michelle Knight, one of three Cleveland women who survived a decade of imprisonment and torture...described being abducted by Castro... Castro offered her a ride...Castro got Knight into his house by telling her he would give her a puppy for her son... Before she knew it, Castro had tied her up on a wall sideways 'like an ornament.' She was eventually taken to the basement where a large, rusty chain was used to tie her body and neck to a pole...She was 21 years old at the time. Knight described a hellish torture in the first few months when she was Castro's lone victim. She was repeatedly punched, whipped and raped....and she said he had a fetish for choking...Eight months after abducting Knight, Castro kidnapped then 16-year-old Amanda Berry...Castro pleaded guilty to 937 counts of rape, kidnapping, torture and aggravated murder and was sentenced to life in prison without parole...He was found dead in his jail cell..." Castro told a judge after accepting a plea deal that would keep him in prison for life that he was "addicted to pornography" (Strauss, 2013).

“Prosecutor: Serial Killer...'Deserves to Die."” Jodi Hernandez and wires. NBC Bay Area, September 16, 2013, http://www.nbcbayarea.com/news/local/Prosecutor-Serial-Killer-Joseph-Naso-Deserves-to-Die-223966191.html.

"[Defendant], 79,...was convicted...of strangling [names of four women omitted]...[Deputy District Attorney Dori Ahana]...showed jurors graphic photos of the victims, pointing out similarities in the strangulation markings...Ahana...argued the slayings were done by a sexually sadistic killer who took pleasure in the victims' suffering and deaths and was only concerned with his sexual self-gratification. The cause of the deaths was strangulation by nylons or pantyhose, Ahana said. 'Nylons are sexually arousing,' Ahana said. And she said they allowed [Defendant] to control how long the victims suffered and when they died...Sighting [sic] testimony that it takes two to five minutes for someone to die of strangulation, Ahana started a two-minute timer during which the courtroom was silent. The prosecution also introduced [Defendant's] 'rape diary' that chronicles his alleged sexual assaults..." Neighbors reported seeing the Defendant "dumping piles of graphic bondage magazines in the rubbish" (McGreal, 2013).

"Horror of...killings in focus: What happened...." Jamie Satterfield. Knoxville News Sentinel, May 19, 2013, http://www.knoxnews.com/news/localnews/horror-of-christiannewsom-killings-in-focus. "[Female Victim] and [male Victim] disappeared Jan. 6, 2007, from the...apartment complex...Hours later, [male Victim's] body was found alongside railroad tracks...He had been raped with an object and then shot three times...He had been gagged with a sock stuffed in his mouth. His ankles were bound with his own belt. His hands were secured behind his back....His head was covered with a sweatshirt tied around his neck with shoestrings...Forensic evidence showed that he had been raped in the final hours of his life. He was forced to walk barefoot to the railroad tracks...and shot.... His body would later be...doused in gasoline and set afire. [Female Victim], meanwhile, was tied up inside [a] house....She was repeatedly raped orally, vaginally and rectally. At some point, she was savagely attacked in her genital region, either kicked or beaten with an object. She suffered two blows to the head...Bleach was sprayed down her throat, an apparent effort to destroy DNA evidence. She was hogtied with 
strips of fabric...Still alive, her body was encased in black garbage bags and her head wrapped in a white plastic grocery bag. [She] was then stuffed inside a trash can and left to die, slowly suffocating." [Author's note: In March 2015, the Tenn. Court of Criminal Appeals upheld the conviction and death sentence of one of the Defendant's in the case.]

"Man admits to torturing Seattle prostitute." John Hauff. Seattlepi, March 25, 2013, http://www.seattlepi.com/local/article/Man-admits-to-torturing-Seattle-prostitute-4382924.php. "A Tacoma man accused of abducting and raping a prostitute at a 'torture room' of his own design has pleaded guilty and will likely face 10 years in prison. [Defendant] was arrested in April 2011 following allegations that he performed a grotesque series of sexual assaults on a 24-year-old prostitute...[Defendant] took the woman to his Tacoma home where she was viciously sexually assaulted in a room apparently built for that purpose. The woman told investigators [Defendant] tortured her for eight hours, during which she was restrained as he shocked her with electrodes, plucked her pubic hair and manipulated her genitals with medical equipment, according to charging documents. [Defendant] allegedly admitted to the allegations during an interview with police. [Defendant], 68, pleaded guilty to a second-degree rape and unlawful imprisonment charges...Taking inspiration from sexual violence described in a long-running series of fantasy novels, [Defendant] was accused of threatening to kill the woman as he sexually assaulted her over several hours...At the property, [Defendant] escorted her into the insulated room, where he attached a chain to her neck...'Police discovered what can best be described as a torture room in the defendant's home, a prosecutor previously told the court. '...The walls are approximately 8 inches thick, making most sounds...almost undetectable." The Seattle Weekly (Kaminsky, 2011) reported that [Defendant] watched "bondage pornography."

"Years after detailing crime, man charged in Tampa drug-torture
death." Elaine Silvestrini. Tampa Tribute, March 18, 2013. http://tbo.com/news/crime/years-after-detailing-crime-man-charged-in-tampadrug-torture-death-515424. "More than seven years after describing for investigators how he watched an associate kill two men and help dispose of the bodies, [Defendant] has been charged with first-degree murder. [Defendant], 47, is serving 40 years in federal prison...on charges of conspiracy and drug-facilitated violence. His associate [Defendant2], 53, is serving 200 years in...federal penitentiary on drug charges in the...2003 deaths of [Victims 1\&2] as well as the drug-induced torture of seven victims who survived...[Defendant2] and [Defendant] were depicted during federal trials in 2005 and 2007 as kindred spirits in a sadomasochistic subculture, centered on fantasies of kidnapping, drugging and sexual torture that turned into a horrific reality...[Defendant2] was convicted of slipping the date-rape drug GHB into the drinks of men he'd lured to his home...[H]e then sexually tortured them." News by WSTP TV (Balut, 2005) reported that jurors in the trial of Defendent 2 were shown images of "unidentified nude men, tied up on [his] bed" and that the men could be heard "begging and squirming in their gags and ropes."

"Leaders urge caution after third gay man found strangled to death." Clare Trapasso. New York Daily News, February 12, 2013, http://www.nydailynews.com/new-york/queens/leaders-urge-caution-gay-man-found-dead-article1.1262128. "The recent strangulation deaths of three middle-aged gay men in Queens and Manhattan has the city's gay community on edge, though authorities say they do not appear to be linked. Elected officials urged the community on Tuesday to take precautions when meeting someone for the first time as police said two 
of the victims may have met their attackers online...[The third Victim], 48, was found tied up with a bag over his head in his apt..."

"Kerb crawler converted van into 'mobile dungeon' to torture prostitute." Reporter. SWNS, (UK), September 17, 2012, http://swns.com/news/kerbcrawler-converted-van-into-mobile-dungeon-to-torture-prostitute-23562/. "A rapist who kidnapped a prostitute and tortured her in the back of his van...has been jailed indefinitely. Evil [Defendant], 40, gagged the 24-year-old woman and strung her up with homemade shackles in his van before brutally raping her for six hours...He pleaded guilty to rape, kidnap and three charges of sexual assault...Andrew Easteal, prosecuting, said: 'He had converted his high-top van into a mobile dungeon, designed so the victim could be restrained and rendered helpless and abused in any way he saw fit........After reaching a remote spot, [Defendant] dragged the woman into the back and shackled her feet with ropes, before using two bungee chords to 'string her up'. He then proceeded to rape and beat her for six hours...Following his arrest, he claimed she consented to sexual activity in the van. He also admitted eight counts of downloading child pornography, of girls aged between six and 15.”

"Detectives: Marine wife... died during sexual attack." R. Stickney et al.. NBC News, August 30, 2012, http://usnews.nbcnews.com/_news/2012/ 08/30/13568388-detectives-marine-wife-brittany-killgore-died-during-sexualattack?lite. "New search warrants...in the murder case of a Marine wife reveal that, according to detectives, [Victim] was an unwilling participant in sadomasochistic sexual activity involving the three suspects accused of killing her...The complaint also accuses the three...of conspiring to kidnap, torture and sexually assault [Victim]. The allegations stem from what investigators believe is the alternative sexual lifestyle the three suspects participated in...[D]etectives say they believe [Victim] was killed during sexual activities with the suspects...Detectives believe [male Defendant] never intended to take [Victim] on a dinner cruise because he picked [her] up...after the boat would've already departed...The documents confirm [Victim] had injuries on her neck, consistent with being strangled...The search warrants also reveal more about the unusual sexual activity prosecutors say was happening at a home...According to the warrant, an ex-girlfriend of [male Defendant] allegedly told police they were involved in bondage, whipping, cutting and spanking. She told police that on one occasion a female was held in the sex dungeon and not allowed to leave without [male Defendant's] permission..." [Author's note: Defendants await trial.]

“Guilty Plea in Sex-Torture Murder Case." Associated Press, CBS St. Louis, August 29, 2012, http://stlouis.cbslocal.com/2012/08/29/guilty-plea-in-sex-torture-murder-case/. "A western Missouri couple [man and woman] already convicted in the sex-torture killing of one woman pleaded guilty...to murdering a second victim...Authorities found the 36-year-old woman's charred remains...while investigating the May 2006 torture, rape and suffocation of 41-year-old [Name omitted] in the couple's...apartment. The apartment...held videotapes of both women being raped and sexually tortured...Prosecutors have said [Defendants] videotaped themselves assaulting the two women to fulfill [male Defendant's] violent sexual fantasies. His criminal history includes a 1987 rape for which he spent nearly 18 years in prison.” A 2006 report (Smith \& Bradley 2006) investigators originally went to the male Defendant's apt because a friend of one of the victim's told them the male Defendant had "shown the [friend] a violent sex film" and that he had told her as the two watched the film that he "would like to have three way 
sex with her and another woman" and that he "planned to strangle the other woman and dispose of her body."

"Texas man gets life in prison in torture case." Associated Press. syracuse.com, February 22, 2012, http://www.syracuse.com/news/index.ssf/ 2012/02/texas_man_gets_life_in_prison.html. “A Texas man who kidnapped his former neighbor and tortured her while holding her captive nearly two weeks was sentenced...to life in prison...After abducting [her]...he drove...to his Corsicana home...Then he whipped and sexually assaulted her on a deer-skinning device. He assaulted her on his bed, where he kept her chained and gagged during most of the ordeal...During closing arguments, Parker County prosecutor Kathleen Catania... walked in front of jurors and held up items seized from his home, she said [Defendant] collected locks, restraints, handcuffs, pepper spray, sex toys, whips, gags, pornography with bondage and rape scenes - and women's underwear...Prosecutor Jeff Swain said [Defendant] has shown a pattern of acting on his sexual fantasies by abusing women....Pearson testified during the trial's penalty phase..., saying she still has problems with her shoulder since her arm was fractured. That happened after [Defendant] chained her wrists to the device in his garage and hoisted her off the ground...In another recorded interview with authorities after his arrest, [Defendant] tells the investigator that was the first time he had done anything like that 'to a complete stranger,' later saying he had tried bondage with his second wife and even used a stun gun on her."

State v. Vollbrecht, 344 Wis. 2d. 69, 820 N.W.2d 443 (Ct. App. 2012), http://wicourts.gov/ca/opinion/DisplayDocument.html?content=html\&seqNo= 85353. "...Vollbrecht was convicted in 1989 of the first-degree sexual assault and murder of [Victim1]. [Victim1] had been found in a wooded area, naked and hanging from a tree by tire chains; she had been shot three times in the back. Vollbrecht was...convicted on circumstantial evidence. Twenty years later, Vollbrecht filed a...motion for a new trial based on newly discovered evidence. Vollbrecht alleged that, at the time of his trial, the State failed to provide the defense with evidence of a third-party perpetrator. The alleged third-party perpetrator, Kim Brown, confessed to and was convicted of a similar killing in an adjacent county only six weeks after [Victim1's] murder. Like [Victim1], Brown's victim was found in a secluded wooded area, partially clothed, bound and shot in the back. Brown confessed to having chained his victim to a tree by her neck...The court summarized the surviving newly discovered evidence as:

The work record of Brown...which indicated that Brown was not working on the night that [Victim1] was murdered.

The testimony, affidavit, and journal of [name omitted] where Brown spoke about liking to chain women to a tree, light them on fire, and shoot them.

The testimony and 1987 affidavit of [name omitted] that Brown stated he liked to chain up women and when he was done with them, burn them.

The statements in the Brown presentence investigation report (PSI) in which he discusses how Brown chained [Victim2] to a tree before he shot her. 
[Name omitted] testimony that sometime around 1992, he overheard Brown tell another inmate that he raped, shot, and tied [Victim2] to a tree, put brush around her and was going to light her up and the lighter failed and he just threw the lighter away. [Author's note: The Court of Appeals of Wisconsin also said that the State had failed to disclose information that a search of Brown's residence uncovered books which included "The Chained and Raped Wife," "Raped and Kidnapped Bride," and "History of Torture."]

“[Defendant] 'developed sexual fetish after watching violent porn films." Martin Evans. Telegraph (UK) October 28, 2011, http://www.telegraph.co.uk/news/uknews/crime/8847951/Vincent-Tabak-developed-sexual-fetish-after-watching-violent-porn-films.html. "[Defendant], who has been found guilty of murdering [Victim], regularly viewed violent pornographic films featuring women being choked, The Daily Telegraph can today reveal. The Dutch engineer also stored images on his computer of a [Victim] look-alike wearing a similar pink t-shirt to the one she had on the night she was killed...Other images found on [Defendant's] home and work computers included a series in which-semi naked women lay bound and gagged in the boot of a car...[A]fter strangling [Victim], [Defendant] placed her body in the boot of his...car... Detectives who seized [Defendant's] laptop computer and two hard drives found evidence that he had viewed a number of violent pornographic films...In some of the scenes, the actors were bound and gagged and in others they were choked before having intercourse. Postmortem examinations on [Victim's] body showed she died as a result of strangulation. Experts were also able to show that [Defendant] logged onto a pornographic website on the morning...he murdered [Victim]...Details of the Dutchman's sinister interest in violent pornography can only now be revealed, after the judge $\mathrm{Mr}$ Justice Field took the decision to rule such evidence inadmissible...During legal argument, the prosecution team...told Mr. Justice Field: 'Pornography depicting violence against women was found in a series of films that the defendant has viewed on his computer...They depict violent images of women being held by the neck. We submit...defendant liked those films...' [Prosecutor] added: 'We submit these have a real significance in explaining why the defendant held [Victim] by the neck and killed her."”

"Law Day event reviews the infamous case of John E. Robinson." Joe Lambe. Kansas City Star (Archive), May 7, 2011. “...Former District Attorney Paul Morrison, who put Robinson on death row in 2003, told the story of an Eagle Scout who turned into a sadistic serial killer...[and] who was perhaps the nation's first serial murderer to work through the Internet...Police...found he posted Internet ads trolling for women interested in bondage and sadomasochism...Robinson signed emails to the women, 'hugs, lashes and kisses'...Police got a break in their investigation when a psychologist from Texas went to them. "He was too mean...and wouldn't return her sex toys and she called the cops," Morrison said. They jailed Robinson for theft and served search warrants on property... Authorities found the bodies of two victims in barrels on the Linn County property and three others in barrels in Cass County..." [Author's note: For the details on this case, see Schiappa, 2001.]

"Bright, Careful and Sadistic: Profiling Long Island's Mystery Serial Killer." Manny Fernandez \& Al Baker. New York Times, April 21, 2011, http://www.nytimes.com/2011/04/22/nyregion/long-island-serial-killer-gets-apersonality-profile.html?_r=0. “...In selecting one large dumping ground, the killer has distinguished himself from Long Island's last two convicted serial 
killers, Joel Rifkin and Robert Shulman, both of whom scattered the bodies of their victims... Only 4 of the 10 sets of remains have been identified. Those four victims...were all in their 20s and had worked as prostitutes...Investigators believe that the deaths of the four prostitutes were the work of a serial killer...The Ocean Parkway serial killer is the third known to have preyed on prostitutes on Long Island in 22 years. Mr. Rifkin, a 34-year-old unemployed gardener..., confessed to killing 17 women between 1989 and 1993...Mr. Shulman, a 42-year-old postal worker..., was convicted of killing and dismembering five prostitutes [before his arrest] in 1996...Besides singling out prostitutes, Mr. Rifkin, Mr. Shulman and the current killer have traits in common. All three are classified by serial-killer experts as organized killers...Long Island's three serial killers might also share similar motives. Fred Klein, the former Nassau County assistant district attorney who prosecuted Mr. Rifkin, said that Mr. Rifkin was driven to kill...out of pleasure. Before he began killing prostitutes, Mr. Rifkin had been obsessed with Alfred Hitchcock's 1972 film 'Frenzy,' about a serial killer in London, and he told officials he used to masturbate to the scenes in which women were strangled. 'It was a psychosexual sadism,' said Mr. Klein...'...Rifkin...would actually get sexual pleasure out of the murder." [Author's note: A news story from the 1990s (Kramer, 1994) reported that Joel Rifkin met one of his victims at Show World Center, a "Times Square porno complex" and that Mr. Rifkin "would regularly stroll the Fantasy Booth aisles, appraising the women...Rifkin also was a habitue of Show World's adjacent Big Top lounge, a boisterous topless/bottomless go-go bar offering table dancing, big-screen porno video...”]

"Suitcase body murder accused viewed 'extreme porn." BBC News, March 23, 2011, http://www.bbc.com/news/uk-england-stoke-staffordshire12842970. "A man accused of murdering a Polish woman he shared a house with viewed extreme pornography on a computer before her death, a court heard...[Defendant]... is also alleged to have searched the internet for 'how to strangle a human being'...[A] computer belonging to [Defendant] had also been used to view a webpage giving details of Polish serial killers. Prosecutor Christopher Hotten, QC, said an Acer computer belonging to [Defendant]...was examined after his arrest. 'The internet browsing history (of the laptop) was examined...,' he said. 'In the day or two leading up to the killing, he...had been viewing not only pornography, but also sites relating to strangulation.' It had been used to access 'hardcore and explicit' pornography..., he added. [Author's note: Defendant was found guilty of murder and sentenced to jail for life.]

"Experts: Kensington Strangler is Classified as 'Sexual Serial Killer." Jessica Hopper. ABC News, January 20, 2011, http://abcnews.go.com/US/confessed-kensington-strangler-antonio-rodriguez/story?id=12648308\&singleP-

age=true. "The man who has confessed to being Philadelphia's 'Kensington Strangler' claims he didn't mean for the women to die, but experts on...serial killers believe the suspect...'enjoyed the act of killing them.' Sources told ABC Affiliate WPVI that [Defendant] has confessed to police that he murdered [three prostitutes, not named here]...He is expected to be formally charged with three counts each of murder, rape, involuntary deviate sexual intercourse and abuse of a corpse...Police sources told the Philadelphia Inquirer that...[Defendant] said he didn't set out to kill the women and that he knew he had to stop. [Defendant] wanted to have 'rough fantasy sex,' choking the women until they were unconscious, but he did not want to kill them, sources told the Inquirer...Forensic psychologist Louis B. Schlesinger said that sexual, serial killers often choose 
strangulation as the method of their murder...'Strangulation allows an individual to control the speed at which the victim dies and this is very sexually stimulating for him,' Schlesinger said. 'It's not uncommon to strangle until almost the point of death, then release the pressure as she [the victim] is about to die so he can increase the time of the sexual strangulation.' Dr. James Alan Fox..., who has written five books about serial killers, said sexual serial killers are uniquely sadistic murderers and [Defendant's] claim that he didn't mean to kill the women is not convincing....'Serial killers are motivated by sexual fantasy and sadism and have a particular type that they're attracted [to]..." [Author's note: Defendant was convicted of raping and killing the three women.]

State v. Webb, 128 Conn. App. 846, 19 A.3d 678 (2011), http://caselaw.findlaw.com/ct-court-of-appeals/1567896.html. "The court went on to discuss other evidence presented at the hearing: 'In addition to the above, the state also presented testimony from Gregg McCrary, a consultant in the field of behavioral criminality. McCrary was previously employed as a special agent with the Federal Bureau of Investigation (FBI), having worked for ten years in the FBI's behavioral science unit...McCrary described a process of crime scene analysis whereby factors ....are reviewed. The goal of this process is to determine whether multiple crimes are linked by signature or are not linked...He examined the homicides that are the subject of the present motion using this crime scene analysis method. His findings and opinion may be summarized as follows...All four women lived in the same area on the east side of Bridgeport. All were non-prostitutes. All were drug users. All were part of the same circle in that they knew each other and were from the same socioeconomic group. There was a sexual component in all four cases...In addition to [the evidence of] strangulation, [the cases of Sharon C., Minnie S. and Elizabeth G. were characterized by] secondary injuries that disfigured each victim in some way. Although the type of secondary injury differed, such injuries were unnecessary to the homicide...As to [Sheila E.], the body was too decomposed to determine the presence of secondary injuries. All four cases were linked forensically. The defendant's DNA was found at each scene...”

"Prostitute tells of surviving 'Crossbow Cannibal." Sarah White. BBC News (UK) , December 21, 2010, http://www.bbc.com/news/10613089. "Lisa [last name omitted] says [Defendant] - who has pleaded guilty to murdering three sex workers in Bradford - showed her violent internet pornography of women being attacked...Although [Defendant] pulled Lisa's hair and pinned her on the bed, leaving bruises, she wasn't concerned for her safety until two months before his arrest. It was then that he started to show her even more violent internet pornography. 'I was shocked, I actually threw up,' she says. 'He was getting a kick out of it.' Lisa says that [Defendant] then got violent, and she wanted to leave his flat. 'I was trying to get out of his flat, it got a bit forceful. He had his hands around my neck. Luckily, I managed to get away."

"Handyman admits to killing at least 8 Mass. women." Stephanie Reitz (Associated Press). NBC News, December 12, 2010, http://www.nbcnews.com/id/ 40629524/ns/us_news-crime_and_courts/t/handyman-admits-killing-leastmass-women/\#.VTb_dCFViko. "He's killed more people than the Son of Sam, but there are no made-for-TV movies about [him]. The one-time handyman...attacked and strangled at least eight women in his hometown of Springfield...The deaths terrorized this western Massachusetts city...as the women's bodies were discovered in alleys, vehicles and their own homes between 1995 and 1998...[Defendant]...met several of his victims in their mutual search for crack cocaine. Others were low- 
income single mothers, often acquaintances, whom he robbed for drug money...In the eight murders, his calling card was brutality: Authorities say several of the women were tightly bound, some had socks or other objects jammed in their throats, and the rapes involved violence that went beyond sexual gratification. [Defendant] blames his actions on the crack cocaine...He says he killed his first victim in April 1995...He beat her with a kitchen pot and bound her with electrical cords. He said he had planned to rape her, but that she strangled first on the cords."

“[Defendant] was considered unlikely to attack again...." Gabriel Baird. Plain Dealer, October 16, 2010, http://blog.cleveland.com/metro/2009/11/anthony_sowell_was_considered.html. "The chances of [Defendant] sexually assaulting another woman after serving 15 years in prison for attempted rape were supposed to be low. That was the conclusion of the report evaluating him...after his June 2005 release from prisons [sic]. The report, reviewed by The Plain Dealer, appears to be horribly wrong. The bodies of 11 women have been found or unearthed at [Defendant's] home...He is in jail facing aggravated murder and rape charges. The report was done...to evaluate whether [Defendant] was a sexual predator. It also provides the most detailed history of [his] life...This conclusion was reached after reviewing [Defendant's] history and interviewing him for 90 minutes...During the interview, [Defendant] was asked about his sexual habits. [Defendant] went to strip clubs, looked at pornographic magazines and watched pornographic videos...” An earlier news story (Martinez, 2009) reported that Defendant also "cruised a sex fetish Web site where he described himself as a 'master' looking for a submissive person "to train" and that the site allowed "people to find each other based on shared sexual fetishes. Some of the options include 'handcuffs/shackles,' 'knife play,' and 'blood.'”

"The case against Colonel Williams: He took videos of the crimes." Christie Blatchford \& Timothy Appleby. Globe and Mail, October 8, 2010, http://www.theglobeandmail.com/news/national/the-case-against-colonel-williams-he-took-videos-of-the-crimes/article4390135/?page=all. “...Colonel Russell Williams videoed part of the two murders and two bizarre sexual assaults he will formally plead guilty to later this month, The Globe and Mail has learned. The videos, confirmed by multiple sources... are the most shocking element of an overwhelming range of evidence against the decorated pilot...He is charged with two counts of first-degree murder in the asphyxiation-torture deaths of 38-year-old [Victim1]...and 27-year-old [Victim2]...; two counts each of sexual assault and forcible confinement in connection with two bizarre attacks in the area last fall...Another driving reason not to go to trial, one police source said, is that there would be 'a lot of stuff that comes in,' much of it pornography - including fetish videos that Col. Williams wanted to prevent being made public... Key evidence in the case-Here are some of the key pieces of physical evidence that contributed to Colonel Russell William's decision to plead guilty. The Videos - Like Paul Bernardo, he videoed much of the suffering he inflicted on his two murder victims, sources say. Police seized that material, and had the case gone to trial, it would likely have been aired in court...Pornography - Police also seized a cache of pornography videos that Col. Williams owned, depicting bondage."

“On the Scale of Evil, Where Do Murderers Rate?" National Public Radio, August 21, 2010, http://www.npr.org/templates/story/story.php?storyId= 129175964. "Columbia University professor Michael Stone knows evil. He's a forensic psychologist - the type of expert that provides testimony on the mental state of accused murderers...Stone has created his own 22-point 'Gradations of Evil' 
scale, made up of murderers in the 20th century...His scale is loosely divided into three tiers. First are impulsive evil-doers...Next are people who lack extreme psychopathic features, but may be psychotic...Last are the profoundly psychopathic...21. Pure Torturers...These psychopaths...are preoccupied with torture 'in the extreme,' but never convicted of murder...Cameron Hooker was born in 1953. As he grew older he read pornography, particularly that which portrayed women being tortured.... He fantasized about having his own sex slave and allegedly reached an agreement with his wife that she could have a baby if he could have a sex slave. After the birth of their child, Hooker kidnapped 20-year-old Colleen Stan in 1977 and kept her captive for seven years. She was whipped, strangled, burned, electrically shocked and raped. For much of that time, she was locked inside a box for 23 hours a day. She and Hooker's wife fled together in 1984. He was convicted and sentenced to 104 years in prison." Psychopathic Torture-Murderers...Most in this category are male serial killers. Jeffrey Dahmer...was sexually molested by a neighbor when he was 8 . At 10 , he was decapitating animals and mounting their heads on stakes...At 17 he committed his first murder, a male hitchhiker whom he bludgeoned, strangled, dismembered and buried. After a failed stint in the Army, his serial killing began in earnest..., ending up with at least 17 victims - all males, some homosexual, like Dahmer. Finally arrested in 1991, he was convicted...of 15 murders and sentenced to 936 years in prison." In an interview conducted by FBI Special Agents (1992, August 3) Dahmer stated (p. 3) that "pornography and masturbation would not satisfy him, but would intensify the obsession and he absolutely had to get another body."

"Detectives solve 30-year-old Bronx murder of Janet Agosto...." Michael Daly. New York Daily News, July 13, 2010, http://www.nydailynews. $\mathrm{com} /$ news/crime/detectives-solve-30-year-old-bronx-murder-janet-agosto-jsusaguilera-killer-article-1.468388. "[T]he...prime suspect is already doing time for two other murders and awaiting trial for yet another. But there remains the question of justice for 20-year-old Janet Agosto of the Bronx, who was first reported missing by her family after she failed to show up for Thanksgiving dinner in 1981.She was found in an abandoned building on Feb. 11, 1982, strangled with a ligature...The detectives took the case as far as they could, but the case went cold for nearly three decades. Then, just the other day, an investigation into a serial killer led to a big break. The serial killer is [Defendant]...As in all the other cases, the victim had been killed with a cord tightened by twisting a stick tourniquetfashion."

"Former Bloomington police office appeals rape conviction based on too much pornography being shown to jury." Mike Riopell. Herald Review, June 9, 2010, http://herald-review.com/news/state-and-regional/former-bloomington-police-office-appeals-rape-conviction-based-on-too/article_5ac05e58-

dbe8-51f0-a5db-eb7797b749cb.html. "An attorney for former Bloomington police officer and convicted rapist [Defendant] argued Tuesday that his conviction should be overturned because the jury in his trial was shown too much pornography from his computer. [Defendant] was convicted in 2008 of raping four women and stalking another. On Tuesday, a panel of three appellate judges...heard oral arguments in his bid to overturn that conviction. [Defendant's] attorney Ryan Wilson argued that the jury...was shown pornography unrelated to [his] alleged crimes, leaving the panel overwhelmed with the amount of illicit material and biased against the former officer. Wilson also said that no link existed proving someone who looks at 
even violent pornography necessarily acts violent as well... Assistant Appellate Prosecutor David Mannchen...agreed that perhaps some of the pornography shown to the jury was irrelevant. But, Mannchen said, much of it was important for the jury to see...[Defendant], 45, was convicted of 25 counts of aggravated criminal sexual assault, three counts of home invasion, two counts of burglary and other counts..." [Author's note: In affirming Defendant's convictions, the Appellate Court of Illinois (People v. Pelo, 404 Ill.App.3d 839 (4th Dist. 2010), describes in detail the hardcore pornography that Defendant watched and the crimes he committed. [It's an opinion well worth reading, at https://www.courtlistener.com/opinion/2482184/people-v-pelo/.]

"Daily Mirror: Los Angeles History." Larry Harnish. Los Angeles Times blog, April 2, 2010, http://latimesblogs.latimes.com/thedailymirror/2010/04/harveyglatman-update.html. "I was recently contacted by Detective Steve Ainsworth of the Boulder County, Colo., Sheriff's Office regarding a 1954 Jane Doe who may be the victim of serial killer Harvey Glatman. Glatman, who was executed in 1959, usually claimed to be a photographer for pulp detective magazines that used cover shots of women who were bound and gagged...Ainsworth is looking for copies of Glatman's photos in an attempt to identify Jane Doe... [Author's note: The following are excerpts from Detective Ainsworth's synopsis of the case:

In July, 1945, Harvey Glatman, DOB/121027, abducted a young girl in Boulder, Colorado, tied her up, and took her up Sunshine Canyon, where he kept her for the night, fondling her while she was tied up. She was released the next morning unharmed...

Between 1945 and 1954, Glatman had numerous incidents in the Denver area in which he would accost women, tie them up and rob them, either for money or souvenirs, but later said he did it just to tie them up...In 1955, Glatman paid Rita Culbertson, Ruby Meadors, a 'Jean' and at least one other unidentified woman in Denver to pose in bondage situations while he photographed them. In January 1957, Glatman moved to California. On $10 / 27 / 58$, Harvey Glatman was arrested by the CHP after attempting to tie up and rape Lorraine Vigil in his car...He had hired her for 'detective magazine photographs'...

A subsequent investigation revealed that Glatman had abducted at least three other California women under the guise of being a photographer for a detective magazine. He would tie them up, take numerous photographs, rape them, then take them to the desert and murder them by strangling them...]

"Killer, serial rapist gets 33 years to life...." Donna J. Miller. Cleveland Plain Dealer, March 17, 2010, http://blog.cleveland.com/metro/2010/03/killer_serial_rapist_gets_33_y.html. "[Defendant], 46, was sentenced to 33 years to life in prison for raping and killing one woman and raping two others in 1994. DNA evidence solved the cold cases. A Cuyahoga County jury convicted [Defendant] of 16 counts of rape. He pleaded guilty to the murder...[Defendant] had raped [the murder Victim] with a Colt 45 beer bottle, hog-tied her, stuffed a sock in her mouth and taped it shut, wrapped a rope around her neck, duct-taped her wrists behind her back and wrapped her in a white sheet. He then put her in a green garbage bag. 
A finger was thrust through the bag, leading investigators to believe she was alive when he bound her."

"Children's charity boss admits string of sadistic sex attacks on prostitutes in 'torture chamber bedroom.'" Daily Mail (UK), March 23, 2010, http://www.dailymail.co.uk/news/article-1260020/Charity-boss-Matthew-

Byrne-admits-torture-sex-attacks-prostitutes.html. "A children's charity boss has admitted a string of sadistic sex attacks on four prostitutes. [Defendant], 38, made his victims dress up as young schoolgirls before carrying out horrific sex assaults on them at his...home. Liverpool Crown Court heard the senior charity worker tied up, gagged and strangled his victims for his own sexual pleasure. He then used a cane to repeatedly beat the women, who were tied to his bed... In another attack he repeatedly whipped his victim until her blood sprayed over his bedroom walls. He then used a plastic bag to suffocate the women until she saw black spots in front of her eyes and thought she was going to die. After being released the woman discovered she had 40 whip marks to her body and legs. When police raided Byrne's home in New Brighton they discovered he had turned a bedroom into a torture chamber. Officers discovered a double bed with shackles attached to each bed post, a leather collar, a cane, rope, tape and girl's clothing. They also found a collection of violent pornography, while his computer revealed he had accessed a string of sadistic websites...He pleaded guilty to four charges of sexual assault and one of assault by penetration between July 1, 2008, and May 31, 2009.”

“...Suspected serial killer...savagely killed his victims because 'He enjoyed it." Christine Pelisek. LA Weekly, February 22, 2010, http://www.laweekly.com/news/orange-county-prosecutor-suspected-serialkiller-and-dating-game-contestant-rodney-alcala-savagely-killed-his-victims-because-he-enjoyed-it-2386307. "At closing arguments today in the trial of suspected serial killer [Defendant]...[a] prosecutor likened the 66-year-old...to a 'hunter' who sadistically and savagely killed his victims because 'he enjoyed it.'...Defendant] is accused of the 1970s brutal rape-murders of [five females., ages 27, 21, 32, 18 and 12]...[Senior Deputy District Attorney Matt] Murphy told the packed courtroom that [Defendant] took his time terrorizing his victims by choking them with his bare hands, waiting for them to wake up at least once, then strangling them again - sometimes using shoelaces or panty hose. 'It is a staggeringly horrific way to die,' exclaimed Murphy. 'There is ample evidence the women put up some resistance.....He gets off on it. It was fun.' Once they were dead, [Defendant] allegedly would then pose their bodies. [The 18-year-old] was strangled, her nipple almost ripped off, and so badly beaten on her head with a rock that a Los Angeles County coroner could not 'distinguish what killed her,' according to testimony. Murphy said that [Defendant] probably...followed [the 21-year-old] home...In horrific testimony, Murphy said she had deep lacerations in her vagina caused by being raped with a hammer...After [Defendant] brutally raped and murdered [the 32-year-old]...'He posed her body, spread her legs and I think he took photos,' said Murphy...Murphy said [the 21-year-old's] ravaged body was also found similarly posed..." [Author's note: Defendant was found guilty of five counts of murder.]

"First Dunbar Village defendant pleads guilty to 14 criminal charges." Missy Diaz. South Florida Sun Sentinel, August 12, 2009, http://www.sun-sentinel.com/news/sfl-lawson-guilty-plea-dunbar-p081209-story.html. "Even for the crime-infested Dunbar Village public housing community, it was an unspeakable attack. A week before trial was set to begin for two of the four teens charged in the 
2007 crime - that made international headlines for its brutality - the youngest of the defendants pleaded guilty as charged today to all 14 counts against him...With no promises of leniency, [Defenant1], 14 at the time and 16 now, agreed to cooperate fully and testify against co-defendants [now ages 18, 17 and 20]...Ten armed, masked men had forced their way into an apartment and over three hours raped and sodomized a woman while beating her 12-year-old son and forcing him to watch the savagery perpetrated on his mother. It ended with the mother and son being forced to have sex, then having household chemicals doused on them in an attempt to cover up the physical evidence."

“Man gets 50 years in Rapids abduction, assault case." Associated Press. Milwaukee Journal Sentinel, July 23, 2009, http://www.jsonline.com/news/wisconsin/51481037.html. "A man who kidnapped and sexually assaulted two young men who were held captive in chains at his central Wisconsin home was sentenced...to 50 years in prison...Prosecutors said [Defendant] preyed on young men who had been drinking. The victims testified at a preliminary hearing that they were handcuffed, blindfolded and taken to [Defendant's] home where they were bound in chains and sexually assaulted. One escaped after several hours and called police. [Defendant's] attorney...called the crimes spur-of-the-moment...But the judge said [Defendant] had been viewing pornography involving men and bondage and that he believed the crimes were planned. 'I think you were a time bomb waiting to go off,' [Judge] Potter told [Defendant].”

"Death sentence upheld in Reno, Sparks slayings." Las Vegas ReviewJournal, June 18, 2009, http://www.reviewjournal.com/news/death-sentenceupheld-reno-sparks-slayings. "A former police officer's death sentence for murdering [a]...school teacher in Reno and a casino worker in Sparks was upheld...by the Nevada Supreme Court...'The remaining aggravators in this case are compelling,' the court said, adding [Defendant] had a history of violence and his torture of [Victim1], who was bitten, shocked by a stun gun and forced into a refrigerator where she suffocated, 'was nothing less than sadistic.'...During his trial, [Defendant] was characterized by prosecutors as a sadist who liked rough sex. Investigators searching his storage unit found restraint devices, sex toys... [Victim1], 45, disappeared...in...1995. Her bound and wrapped body was found about a week later... [Victim2] was 42 when she disappeared....Her body, wrapped in plastic and bound with rope...was found...in...1995.”

"Fritzl finally cracks after brave daughter faces him across court." Alan Hall. Daily Mail (UK), March 19, 2009, http://www.dailymail.co.uk/news/article1162591/I-realised-cruel-I-Fritzl-finally-cracks-brave-daughter-faces-court.html.

"Josef Fritzl's resistance finally broke yesterday after he came face to face at his trial with the daughter...The court had heard how the sexually-obsessed building engineer locked up Elisabeth when she was 18 in a secret cellar beneath his home...For the next 24 years he would rape her up to 3,000 times and father seven children by her...Fritzl claims Elisabeth was sliding into a life of drink and debauchery and that he was 'saving her from herself'...But she spoke of being a normal teenager...'Somehow, I don't know why, my father seemed to choose me for himself,' she said. He began abusing her when she was 11, fondling her and leaving pornographic magazines under her pillow...She neither wept nor faltered as she recounted the ordeal...when Fritzl asked her to go down to the cellar to help him install a door. He overpowered her, knocked her out with medical ether and left her in the cellar. A day later he returned with a chain and began the rapes....Jurors were both repelled and spellbound as Elisabeth recounted how she spent the 
first...months...chained to four poles with an iron girdle around her waist...The rapes averaged out to one every three days, but there were occasions...when there were none, and some when he raped her more than once a day. She told of 'constant beatings and kickings all over my body.' Later, after 1989, he would come to the cellar armed with boxes of lurid pornographic videos which he would play while ordering Elisabeth to mimic the actors. She also spoke of sex toys being used upon her in violent sessions lasting many hours that left her with grave internal injuries."

“Serial Killer Pleads Guilty, Avoids Death Penalty." WSOC-TV, July 18, 2008, http://www.wsoctv.com/news/news/serial-killer-pleads-guilty-avoidsdeath-penalty/nG3dc/. "An accused serial killer has been sentenced for kidnapping, raping and killing three women... The women were shot and their mutilated bodies were dumped near rural roads...He also pleaded guilty to crimes involving two more women, including attempted first-degree murder and first-degree sex offense...Records show investigators seized assorted whips, chains, handcuffs, knives and handguns from [Defendant's] home. Detectives said...they also found pornography...Union County Sheriff Eddie Cathey has said that [Defendant] and the three dead women knew each other because they 'lived a high-risk lifestyle, and he was a part of that high-risk lifestyle.' [One Victim] had been charged with prostitution seven months before she died..."

"Unspeakable horrors as trial opens in torture and rape of Columbia student." Barbara Ross \& Corky Siemaszko. New York Daily News, June 6, 2008, http://www.nydailynews.com/news/crime/unspeakable-horrors-trial-opens-torture-rape-columbia-student-article-1.294967. "A Columbia journalism student will tell jurors on Friday how a sadist turned her Manhattan apartment into a 'torture chamber' where she was raped, disfigured and nearly blinded. 'He ordered her to stab out her eyes,' Assistant District Attorney Ann Prunty said...as she opened the trial of 31-year-old [Defendant] with a horrific account of the alleged assault...Standing naked in the bathtub with her lips glued and taped shut, her hands and ankles bound, the 23-year-old victim 'couldn't do it,' Prunty said. 'The next thing she heard was the kettle whistling,' the prosecutor said. 'She will never be able to stand that sound again.' Prunty's description of how Williams allegedly poured the boiling water on his victim stunned the packed Manhattan courtroom into silence and caused a veteran sketch artist to flee in tears. The testimony that followed was even more gruesome..." [Author's note: A jury subsequently convicted Defendant on 44 counts of attempted murder, kidnapping, arson, rape, sodomy and burglary. In the extensive coverage of the horrific crime, only the New York Times (Eligon, 2007) reported that the Victim had testified that before raping her he "asked her to turn her television to a pornographic channel."]

"Killer who used samurai sword gets 40 years in prison." Colleen Jenkins. Tampa Bay Times, May 16, 2008, http://www.tampabay.com/news/courts/crimihttp://tampabay.com/news/courts/criminal/killerwho-used-samurai-sword-gets-40-years-in-prison/511032. "For killing a man with a samurai sword, [Defendant]. received a 40-year prison sentence...[Defendant], 47, claims he wanted only to protect his young daughters from their mother's new sex offender boyfriend...Assistant State Attorney Jennifer Gabbard noted the irony of his defense: [Defendant], too, is a registered sex offender. He and his estranged wife... served prison time for the October 1987 kidnapping and sexual torture of a 21-year-old woman, one of the most horrific sex crimes in the county's history, Gabbard said." [Author's note: The Tampa Tribune (Lamm, 1987) described the 1987 attack as follows: 
The victim was then taken to the...residence, where she was bound, gagged and threatened with a knife and gun, police said. Police said the two women then held the victim down while the men raped her. The victim was badly beaten, shaved, burned and had her vagina and eyes glued, police said. Police said her vagina was later set on fire.]

"Student charged in attacks on sex trade workers." Hamilton Spectator, January 17, 2008, http://www.thespec.com/news-story/2125944-studentcharged-in-attacks-on-sex-trade-workers/. "A Mohawk College student has been charged with violent attacks on three Hamilton prostitutes and is the prime suspect in several more...He is now charged with three counts each of sexual assault, choking, unlawful confinement, and forced anal intercourse...[P]olice made a random traffic stop after seeing an erratically driven car...Inside, they found an extremely distraught female passenger who told officers she'd been sexually assaulted. The woman, a sex trade worker in her 30 s, required treatment in a Hamilton hospital. 'This was a substantial, violent sexual assault,' said acting Detective Sergeant...'We believe there are number of cases here that are related."' [Author's note: Defendant pleaded guilty to raping four women.]

“Rapist in '92 case heads back to jail." Michael P. Mayko. Connecticut Post Online, January 14, 2008. "A man who brutally raped a Trumbull woman in front of her three children a decade ago is going back to state prison after possessing thousands of images of rape pornography on his three computers and stalking an Orange woman who notice him following her...After concluding that Supervisory State's Attorney John Smriga proved [Defendant] violated his probation in the Trumbull case, [Judge] Devlin ordered that [Defendant] serve the remaining 12 years of prison time for that crime...Smirga said there was also a film depicting two men breaking into a woman's home. When the woman...comes home, the men 'tie her up, torture her, humiliate her and then sexually assault her,' the prosecutor said.”

"Police seek fugitive and infant girl." Molly Hennessy-Fiske. Los Angeles Times, December 14, 2007, http://www.latimes.com/la-me-fugitive-141207story.html. "Authorities searched...for a fugitive...already wanted...on suspicion of kidnapping, raping and torturing his girlfriend... [Defendant] was featured last month on 'America's Most Wanted,'... [Defendant's] girlfriend told Pomona police that he had held her captive in an abandoned apartment while he smoked methamphetamine. Although she managed to escape...seeking treatment at a hospital, [Defendant] found her and forced her back into captivity for about a week, she told police. During that time, she said, [Defendant] raped her with a beer bottle and flashlight and stabbed her with a screwdriver more than 30 times. 'He told the victim that her pain was a rush to him,' [Police Sgt. Matt] Stone said." [Author's note: Defendant was convicted of numerous crimes, including corporal injury to a cohabitant, kidnapping to commit rape and oral copulation, several sex crimes, and assault with a deadly weapon. The California Court of Appeal (at http://www.insidesocal.com/iecourts/files/import/35595-121509\%20Alderete\%20Appellate\%20Ruling.pdf) affirmed his conviction in 2009. In so doing the Court of Appeal stated in part:

Two incidents occurred [in February] 2007: appellant choked Jane Doe until her body went into convulsions and she passed out, and he forced her to lie down on a bench....and repeatedly pushed a beer bottle into her vagina...While in the car, appellant demanded that Jane Doe perform oral 
sex...During the act, appellant hit her head with a closed fist. Later, he forced a flashlight into her vagina, repeatedly putting it in and out. He also hit her on the leg with a long metal bar...She was examined by a nurse specializing in sexual assault forensic examinations. Jane Doe had multiple puncture wounds and bruises on her face, chest, and everywhere on her body except her abdomen, as well as tearing in her vaginal area. The injuries were consistent with the history she gave.]

“Bail set at \$500,000 for assault suspect....” Brian Huber. Waukesha Freeman, September 20, 2007. “...[Defendant], 25, was charged...with one count of second-degree recklessly endangering safety, one count of false imprisonment and three counts of second-degree sexual assault... According to the complaint in the case, the woman, 27, had been seeing [Defendant]...On September 10, [Defendant] came to her house...That night, the woman allegedly woke up to see [Defendant] straddling her, holding a knife..., the complaint said. [Defendant] then used duct tape to bind the woman's arms and legs behind her back and stuffed a T-shirt into her mouth and sexually assaulted her during the night while a pornographic tape that [Defendant] brought with him was playing, the complaint alleged. The woman reported that [Defendant] used crack cocaine during the night...Investigators also seized a pornographic DVD [at Victim's home] that contained a scene were a woman was similarly bound with duct tape, the complaint alleged." [Author's note: Defendant pled no-contest to second-degree sexual assault as a repeater, seconddegree recklessly endangering safety and false imprisonment.]

“Guilty plea in Glen Cove dismemberment case.” Ann Givens. New York Newsday, September 12, 2007. "The defendant in one of the most gruesome murder cases in Long Island history pleaded guilty... securing a promise of 30 years to life in prison...[Defendant], 32, became a suspect in [Victim's] murder...when [Defendant's] mother...told police that they could search her home. Police found [Victim's] body cut apart and divided between two trash cans in the basement. The [Victim's head was missing. The following morning, police stopped...[Defendant] as he drove into his mother's...neighborhood. The head was in a duffel bag in his trunk...In admitting to the crime in court,...[Defendant] said that he broke into [Victim's] home to steal money for drugs. Police...have said that [Defendant] had broken into her house to fulfill some kind of morbid psychosexual fantasy. Near where they found [Victim's] body, police found evidence of violent sexual fetishes, including several mannequins and mannequin heads, sadistic and violent pornography and horror videos, various sexual devices and a board with sexually graphic and violent photos attached to it, as well as one sketch of a woman being decapitated."

"Pig farmer 'hung dead prostitute from a chain." Tom Leonard. Telegraph (UK), June 27, 2007, http://www.telegraph.co.uk/news/worldnews/1555721/Pigfarmer-hung-dead-prostitute-from-a-chain.html. "A former acquaintance of a pig farmer accused of being Canada's most prolific serial killer told a court that she once found him in his slaughterhouse smeared in blood and next to a woman's body hanging from a chain. [Witness] said that [Defendant], who is accused of murdering 26 women, pulled her inside and threatened that she would end up 'right beside her' if she didn't keep quiet...[Witness], a self-confessed crack cocaine addict, said she had recognised the dead woman as a prostitute whom she and [Defendant] had picked up earlier that night and brought back to his ramshackle farm outside Vancouver, British Columbia... [Witness] said that on the night in 
question, [Defendant] had gone to his room with the prostitute...She said she later heard a noise, saw a light in the slaughterhouse and went to investigate. Asked how the body was hanging, she said: 'The same way he hung his pigs. There was a chain right there. That's where she was, where he does his pigs." [Author's note: [Defendant] was convicted of murdering six women, all of whom were prostitutes.]

"Sick world of perv e-lust." Laura Italiano. New York Post, May 4, 2007, http://nypost.com/2007/05/04/sick-world-of-perv-e-lust/. “'Chloroform,' [Defendant] typed into his computer. 'Girls. Rape. Video.' The fiend kept typing - using several search engines to plumb the darkest recesses of the Internet... '...Chloroform kidnap videos.' A year or more before his grotesque...attack in Chelsea on a helpless ex-co-worker, the so-called 'fire fiend' repeatedly scoured the Internet for images of beautiful women being drugged and abused, according to riveting testimony in his kidnap-sex-assault case yesterday. [Defendant's] searches...yielded graphic, rape-scenario pornography that offers virtually a mirror image of his later attack, in which he chloroformed, stripped, bound and molested his captive over the course of 13 hours...Barred from jurors' sight are dozens of additional photos from [Defendant's] creepy cache. In them, women, many of them nude, are tied to beds, sometimes wearing high heels, and sometimes with their mouths taped shut - all humiliations [Defendant] later forced upon his victim. Another of [Defendant's] pictures shows a man cutting off a woman's panties with a knife - exactly as his victim testified he did to her. 'They show what he was looking at, where he was getting the ideas to commit the acts he committed,' prosecutor Maxine Rosenthal argued in asking they come into evidence..." [Author's note: Defendant was convicted of kidnapping, burglary, sex abuse and robbery charges.]

“From a meek 'nobody' to a serial killer?" Mary Foster. Seattle Times, December 6, 2006, http://www.seattletimes.com/nation-world/from-a-meek-nobody-to-a-serial-killer/. “...Even with a meek persona, investigators said, [Defendant] bound and strangled or smothered 23 men and teenage boys in southern Louisiana...[Defendant] apparently was able to charm his victims into accompanying him, said Les Bonano, director of investigations for the state attorney general's office...[Defendant] is believed to have raped his victims before killing them, [Sheriff] Larpenter said...'He said he killed them because he didn't want to get caught,' Larpenter said. 'But I would think he discovered...that it was not just because of that. I think he discovered he liked it.' All the victims were homeless males, ranging from 16 to 46, all were strangled or asphyxiated and all the bodies were bound...The break in the case came when an ex-con told his parole agent about getting away from a man who wanted to tie him up for sex, Larpenter said." [Author's note: Defendant pleaded guilty to 8 counts of first degree murder.]

“Trucker on Trial in Deaths of Four Called a 'Monster." Maeve Reston. Los Angeles Times, June 15, 2006, http://articles.latimes.com/2006/ jun $/ 15 /$ local/me-ford15. "As he traveled across the state, long-haul trucker [Defendant] combed dark roadways for...women desperate enough to climb into the cab of his truck and trade sex for cash....Four women did vanish in 1997 and 1998 after being picked up by [Defendant], and their naked bodies - some of them dismembered - washed up in aqueducts and other waterways. The killings stopped when [Defendant]...confessed to the slayings, which he said were accidental...'The defendant is a sexual sadist.... It is the infliction of pain and suffering that arouses him,' [the Prosecutor] told the jury. 'You might give him the first one,' he said, scoffing..., 'but if you repeatedly do an act over and over again -- is that an 
accident?' [The] Deputy Public Defender... told jurors...they must weigh the possibility that his client took rough sexual acts too far, but did not intend to kill the women...When he turned himself in, [Defendant] ...told authorities that he frequently engaged in 'erotic asphyxiation,' which entails constricting the flow of oxygen to the brain by strangling one's partners to enhance their sexual pleasure, sometimes reviving them with CPR." [Author's note: A jury found Defendant guilty of four counts of first degree murder]

“Handyman gets life in rape slay...." Jeane MacIntosh. New York Post, May 16, 2006, http://nypost.com/2006/05/16/handyman-gets-life-in-rape-slay-youstole-the-love-of-my-life/. "A day laborer convicted of the barbaric rape and murder of a Rockland County mother of two was sentenced to life without parole...[Widower Dan] Nagle, 42, said the Guatemalan handyman 'beat, cut, raped, sodomized and strangled the greatest love of my life and the mother of my two children.' Defense lawyer Barry Weiss acknowledged that the murder 'was an act of evil' but claimed 'what happened ... was rage [fueled] by alcohol and cocaine."

"Fiends guilty of coed slay - Face life for rape \& torture." Daniel Friedman. New York Post, March 24, 2006, http://nypost.com/2006/03/24/fiendsguilty-of-coed-slay-face-life-for-rape-torture/. "Two reputed members of the notorious Bloods street gang were convicted yesterday for the horrific 2003 rape, torture and murder of 21-year-old Hunter College honors student [Victim]. In verdicts reached by two separate Brooklyn Supreme Court juries, [Defendant], 23, and [Defendant2], 22, were found guilty of first-degree murder, kidnap, rape and sodomy for abducting the psychology major and holding her as a sex slave in an East Flatbush basement apartment before murdering her. The two...were also found guilty of kidnapping, raping and sodomizing a 15-year-old girl in the apartment just days after [Victim's] murder...[Victim] had been walking...when she was grabbed by the pair and taken to [Defendant2's]...apartment. The two men repeatedly raped and sodomized her. They also burned her face with cigarettes, cut her hands and feet with a saw, beat her senseless with a dumb bell and finally killed her with a hammer. [Author's note: A news story in the The New York Times (Brick, 2006) reported that the two defendants lured the Victim to the apt "for thrills."]

“Jury says sentence killer to die.” Christy Gutowski. Daily Herald (Chicago), February 28, 2006. "A jury recommended...that [Defendant] be executed...The same Cook County jury rejected [Defendant's] insanity defense...for the rape and murder of [a mother and her 10-year-old child] as they lay side by side with bound hands in their...apartment. Jurors also heard testimony of five other sex slays [Defendant] is charged with...The women were beaten, raped, sodomized, tortured, strangled or had their throats slashed. Their bodies were set on fire or chopped into pieces and dumped...Experts agreed [Defendant] is a sexual sadist...The jury also learned a lot about [Defendant's] sexual development. He told doctors he began masturbating up to three times daily in fifth grade, usually while looking at porn. He fixates on women's legs." [Author's note: In affirming Defendant's conviction and death sentence in 2009, the Illinois Supreme Court provided extensive detail about the horrific crimes committed by the Defendant. The opinion is published at http://www.ecases.us/case/ill/2027167/people-v-runge.]

“City Beauty Slain by Beast: Tortured \& dumped by road." Veronika Belenkaya \& Alison Gendar. New York Daily News, February 28, 2006, http://www.nydailynews.com/archives/news/city-beauty-slain-beast-tortureddumped-road-article-1.564584. "She was a graduate student with brains to match 
her beauty who came to New York to study criminal justice - but wound up the victim of an unspeakably horrible murder. A monster tortured vivacious [Victim] - brutally raping her, chopping her dark hair and stuffing a tube sock down her throat. Then he wrapped her face in tape and dumped her nude, bound body off a Brooklyn road...'It looks like she died in excruciating pain,' said a source who saw the gruesome morgue photographs...Her face, from her forehead to chin, was covered with vertical strips of clear packing tape. Her hands were tied behind her back, ankles bound...She had marks on her chest and her genitals were lacerated, sources said, adding that she also had been raped and sodomized. The city's medical examiner ruled she had been suffocated - someone pressed on her windpipe while her mouth and nose were covered." [Author's note: A jury convicted the defendant of murder. In another article, the Daily News (Alison Gendar \& Adam Lisberg, "Beast May Strike Again,” 3/1/06) reported: [Victim's] battered face and nude body bore the signs of a sexually deviant murderer. She was raped, sodomized and suffocated. Her dark hair was chopped short, her genitals sliced and a tube sock jammed down her throat, sources said. The killer also covered her face with vertical strips of clear packing tape from forehead to chin, sources said. Forensic experts said the tape could be a sign that the attacker was acting out fantasies of bondage...'You can still see the face,' forensic psychologist Marta Weber said. 'That's important. Why is the face being preserved? Is it to see the person's agony?']

“As Killer Faces Sentencing, His Motive Remains Elusive." Damien Cave. New York Times, January 27, 2006, http://www.nytimes.com/2006/01/27/nyregion/27murder.html?pagewanted=all\&_r=0. "One of the green plastic trash bags dumped 14 years ago off Route 72 in South Jersey contained the head of a man. Another bag held his torso and severed arms, while his legs were found in a third. Ten months later, more bags surfaced. The police in Manchester Township...found six bags near a dirt road, filled with the body parts of another man. [Defendant], a Staten Island nurse, was convicted in November of murdering the two, [Victim1], $57, \ldots$ described by prosecutors as bisexual, and [Victim2], 44, identified as a prostitute...[Defendant] is suspected of at least two other murders...'The big unanswered question in this case is why,' said William Heisler, the Ocean County prosecutor who presented the case at a two-week trial ...'For whatever reason, he was targeting gay men in New York....[Victim1's] death suggested a pattern. A year earlier, on May 5, 1991, the mutilated body of [a possible Victim]...was found wrapped in green plastic garbage bags...By the fall of 1993, two more bodies of gay men had been found...The murderer became known as the 'last call killer.' The victims were drunk to the point of incapacitation when they were stabbed...[Defendant] was arrested...When investigators searched his home...they found a...sedative that can be used as a date-rape drug... and 'several photographs of unknown men on which stab wounds had been drawn,' according to court documents." [Author's note: In affirming Defendant's convictions, the NJ Superior Court, Appellate Division, mentioned in passing that police also found "Hush, Hush, Sweet Charlotte," a video which "contained scenes including the chopping off of a hand with a meat cleaver and other acts of body dismemberment, including decapitation." The Court's opinion is at http://law.justia.com/cases/new-jersey/appellate-division-unpublished/2008/a5885-05-opn.htm.]

“Brooklyn Man Is Convicted In Sex Assaults." Thomas J. Lueck. New York Times, August 18, 2004, http://www.nytimes.com/2004/08/18/nyregion/brooklyn-man-is-convicted-in-sex-assaults.html. "A Brooklyn man who was charged in a series of sexual assaults across the city...was convicted yesterday of rape and 
sodomy in attacks on nine women in the Bronx over the course of a decade, the authorities said. [Defendant], 36,...was convicted of 14 counts of first-degree rape and five counts of sodomy in attacks from 1993 through 2002 that took place in apartments, alleyways and on rooftops, according to the Bronx district attorney, Robert Johnson...The authorities said [Defendant], whose victims ranged in age from 13 to 58, was linked to the crimes through DNA evidence...Mr. Johnson said [Defendant], who assaulted some of his victims repeatedly, almost always used or threatened violence. All but two of the attacks were at knife point, and four of the women were choked into unconsciousness, Mr. Johnson said. [Defendant] has been charged separately in a series of sexual assaults in Queens...”

“Sex-slay sick gets 25 years.” Laura Italiano. New York Post, April 23, 2004, http://nypost.com/2004/04/23/sex-slay-sicko-gets-25-years/. "Two years ago, a notorious neighborhood thief...left an elderly woman stripped, sexually violated and gasping her final breaths in her Chelsea bathtub...Once questioned, [Defendant, age 67] amazingly claimed he had had consensual rough sex with the diminutive and reclusive seamstress - and that the strangle marks on her neck were caused by his attempt to save her life by pulling her out of her bathtub by her neck. He goes to prison unrepentant. 'You forced yourself on this woman sexually,' Manhattan Supreme Court Justice Marcy Kahn said before imposing sentence. 'You beat her in her own home, breaking most of her ribs, and finally you took her life from her by strangling her to death. She could not fight back, although she tried,' the judge said."

“Killer was obsessed by porn website." Steven Morris. Guardian (UK), February 5, 2004, http://www.theguardian.com/technology/2004/feb/05/newmedia.crime. The family of a teacher who was murdered by a man obsessed with websites showing graphic images of extreme violence against women yesterday called for the internet to be more closely regulated... The court heard [Defendant] had been examining such sites the day before he strangled the special needs teacher with a pair of nylon tights...Police...traced former girlfriends, who described how he liked to tie them up and apply pressure to their necks during sex until they almost passed out...[A former girlfriend] also revealed she had discovered a stash of pornographic pictures of women. Around their necks [Defendant] had drawn nooses. In the witness box, [Defendant] conceded that surfing the net for pornography had become an 'addiction', and said that since he was 15 or 16 he had a 'fetish' for women's necks.”

“Haunted by Rape: New arrest shakes up '83 victim.” Jamie Schram. New York Post, June 5, 2003, http://nypost.com/2003/06/05/haunted-by-rape-newarrest-shakes-up-83-victim/. "The news yesterday that registered sex offender [Defendant] was accused of a Manhattan sex attack forced Laura Lee Schreiber to relive a sickening nightmare...Schreiber, 40, spent the day...rereading the news that [Defendant] , who spent 17 years behind bars for raping and terrorizing her, was accused of attacking a woman in an office building where he worked...It was...1983, and Schreiber, a 21-year-old from Canfield, Ohio, had spent the day moving new furniture into her second-floor apartment...When [Defendant] rang her buzzer, she let him in without a worry. She knew him in passing as a...handyman from the neighborhood...Augustine excused himself to use her bathroom. When he returned...'He suddenly became like another person...,' Schreiber said. She remembered how Augustine put the knife's...blade to her throat, warning her...After pummeling her and binding her hands and feet with the masking tape and some wire, [Defendant] stuffed a piece of cloth into her mouth and slapped 
tape over it before spending the next five hours raping and sodomizing her..." [Author's note: Details about the 2003 crime can be found at Weir, 2003.]

"EIU trial drew disturbing portrait." Aamer Madhani. Chicago Tribune, March 3, 2003, http://articles.chicagotribune.com/2003-03-03/news/030303 01791 death-penalty-death-row-abused. "For most of the state, [Defendant's] sentencing last week was a significant epilogue, the first death penalty handed down...But in this college town...the jury's quick verdict capped a much more personal and disturbing story - the unmasking of a violent killer who police now say had raped and burned and murdered before, leaving a years-long trail of horror. In a trial that riveted Charleston..., [Defendant], 26, was convicted of the 2001 murder of fellow Eastern Illinois University student Shannon McNamara. DNA and other evidence left courtroom spectators with few doubts that Mertz raped, strangled and mutilated McNamara. Then, in his sentencing hearing, the surprises began. Several women came forward to testify that Mertz had abused them, sexually and physically." [Author's note: In People v. Mertz, 842 N.E.2d 618 (2005), athttp://caselaw.findlaw.com/summary/opinion/il-supreme-court/2005/11/17 1133787.html, the Illinois Supreme Court affirmed Defendant's convictions and death sentence, stating in part: We first find that all evidence of a sexual nature was properly admitted, including Internet images of women engaging in sexual acts with a dog and a horse, women in sexually explicit positions, nude children, sexually explicit cartoons, and the articles on date rape...as were nude photos of defendant's girlfriends...Evidence of defendant's obsession with sex was properly admitted because both the McNamara and Warner murders had sexual components, there was evidence that defendant had used violence or force in other sexual encounters, and defendant had, in other ways, demeaned and denigrated some of the women with whom he had had relationships. Thus, evidence of this nature bore upon the issue of defendant's future dangerousness.]

"Psycho sex fiend: Rape-bid suspect." Denise Buffa. New York Post, January 21, 2003, http://nypost.com/2003/01/21/psycho-sex-fiend-rape-bid-suspecteyed-in-two-slays/. "Authorities believe [Defendant] was on his way to becoming New York's next serial killer. The 43-year-old suspected psycho killer - busted last February while allegedly attempting to rape a streetwalker in Brooklyn's BedfordStuyvesant - is now suspected of strangling two other hookers in earlier attacks in a chilling pattern of sexual assault and murder. 'He certainly could've become a serial killer if he hadn't been interrupted,' Assistant DA Heidi Mason said... Cops nabbed...and charged him with attempted rape...after a passer-by heard the screams of a woman whose wrist had been slashed to the bone with a razor. Cops had to pry [Defendant] off his victim, authorities said...There were uncanny similarities between the suffocation of [Victim1], a 40-year-old mother of eight, and the strangulation of [Victim2], 36, who had a 5-year-old son. Both were African-Americans, close in age, who sold their bodies in Bedford-Stuyvesant to feed crack habits. And both were found nearly naked, face-down in playgrounds..." [Author's note: Defendant was found guilty of murder and rape.]

Vernon J. Geberth, Sex-Related Homicide and Death Investigation: Practical and Clinical Perspectives, CRC Press (2003) (pp. 44-45). "Case 4 Continued...'When I got to Denver there were a lot of sex shops. There I found bondage magazines and videos. Magazines of beautiful women and young girls tied, bound and gagged in just about every way possible. I was in heaven. I bought lots of mags and videos. After a year or so of watching I wanted the real thing. I wanted a woman bound up and sexually abused...I didn't want a willing partner...I 
wanted an unwilling partner. I would go out and walk the streets and visit clubs looking for the right woman or girl."' [Following the quoted material, Geberth comments, "In many cases, the offenders used girlfriends or prostitutes to act out their sadistic fantasies... [F]rom an investigative perspective, the sexual crimes committed by the offenders and the activities they engaged in with consenting partners were almost mirror image scenarios.”

Vernon J. Geberth, Sex-Related Homicide and Death Investigation: Practical and Clinical Perspectives, CRC Press (2003) (p.45). "Case 5: Serial Rapist's Diary...[T]he sexual bondage and discipline magazines he purchased were reflected in his behavior with consenting partners as well as his victims...My review of the [perpetrator's] journal entries indicated a progression of activities, as the offender repeatedly acted out the scenarios depicted in the magazines and incorporated the pictures of the bound women into his fantasy system."

Vernon J. Geberth, Sex-Related Homicide and Death Investigation: Practical and Clinical Perspectives, CRC Press (2003) (pp.52-54). "Case 10: Serial Killer's Fantasy...In Chapter 10, the author presents a serial murder involving Maury Travis. The offender was heavily vested in bondage fantasy...Detectives located a paperback book that contained information on acts of sadism...Taped inside the book were newspaper articles about a young woman who had been held captive by her neighbor. The man had built a bunker (cell) in his basement to keep this young girl as a sex slave. Investigators also located several drawings and information that Travis had gathered relative to building a concrete block cell...Travis made reference to various books and Web sites relative to bondage and torture...The offender was heavily into S\&M and had videotaped some of his activities as he acted out his fantasies with his victims.

Vernon J. Geberth, Sex-Related Homicide and Death Investigation: Practical and Clinical Perspectives, CRC Press (2003) (pp. 57-58). "Case 11: Serial Killer...Each crime was characterized by prolonged and sadistic assaults on his victims, whom he seemingly played with as he tortured them for hours...The offender focused his attacks on specific body regions, particularly the breasts and literally bit into their breasts. Investigation revealed that the offender had an intense interest in bondage and total control and submission of his victims... When the authorities in this case executed a search warrant at the subject's home, they discovered that he maintained a private room in the house...Among the many items recovered in this room was an extensive collection of B\&D [Bondage \& Discipline] materials and other pornography, which indicated the subject's intense interest in sadomasochistic activities...”

Vernon J. Geberth, Sex-Related Homicide and Death Investigation: Practical and Clinical Perspectives, CRC Press (2003) (pp. 61-62). "Case 12 ...This case involved a serial killer who was killing prostitutes...Once he completed the sex act, he stripped and tortured them for hours...The significance of fantasy in this case was graphically revealed when...detectives went to the killer's home and retrieved a number of items, including one pornographic videotape... This videotape contained a number of scenes that were similar to what the offender was doing to his victims. The breast assault and paddling activities appeared to be based upon this sadomasochistic videotape, which seemingly fueled his increasingly sadistic activities..."

Vernon J. Geberth, Sex-Related Homicide and Death Investigation: Practical and Clinical Perspectives, CRC Press (2003) (pp. 68-83). "This 
case presented a murder/suicide...Susan's body was in a supine position...She suffered a number of stab wounds into her chest and breast. The stab wounds continued down her chest into her pubic and pelvic area, and her throat was cut. Telephone cord had been wrapped tightly around her neck...and it was apparent that Frank had positioned his wife's body in a pose similar to some of the drawings police recovered...The police discovered 115 drawings and 105 photographs of nude women. There were also 83 men's magazines, including High Society, Gallery and Penthouse. Many of the magazines had pages removed, including pictures of centerfolds with stab marks. Frank also maintained an extensive collection of...pornographic videotapes...The numerous photographs of nude women from magazines with knife holes and simulated bullet holes through the pictures displayed his obsession with sexual mutilation of women."

"Internet Used to Find Man Who Is Charged in 2 of 10 Killings." Associated Press. New York Times, June 11, 2002, http://www.nytimes.com/ 2002/06/11/us/internet-used-to-find-man-who-is-charged-in-2-of-10-kil-

ings.html. "Investigators looking into the killings of 10 women in the St. Louis area have accused a paroled robber in two of the killings after tracking him using the Internet...The complaint...accused [Defendant] of kidnapping, torturing and killing two prostitutes...A search of [Defendant's] home found restraints...A team of detectives has been investigating the deaths of 10 women in the St. Louis area since April 2001. Six of those women were prostitutes with drug habits; the other four have not yet been identified. The federal complaint says that...after the Post-Dispatch profiled another of the 10 victims,...the newspaper received a letter...Four days later, investigators determined that the return address on the letter, [Name omitted] was a Web site featuring bondage and sexual torture..."

"Confession of a Sex Slayer." Maria Bovsun. New York Daily News ("The Justice Story”), August 8, 2001. “...Three times, Moser, an amateur criminologist, had written the state police, only to have his letters ignored. Eventually, he approached the FBI. 'I think I know who murdered the Jackson family,' Moser told them [in 1959]. He named a childhood buddy, Melvin Davis Rees...Rees was a fan of the writings of the Marquis de Sade, Moser said...[H]e was also hooked on Benzedrine....Moser [had] really started to worry after the June 1957 slaying of Margaret Harold...Harold was found dead...near a dilapidated shack wallpapered with a pinup gallery of porn...When Mildred [Jackson] was found not far from the porno shack [in 1959], Moser decided to contact authorities...An FBI search of the Rees family home turned up...newspaper photos of the Jackson family with bloodcurdling notes in Rees' handwriting...'Drove to select area and killed husband and baby. Now the mother and daughter were mine,' one entry read. After detailing Mildred's rape, it ended with, 'then tied and gagged and led her to the place of execution and hung her." [Author's note: Rees appealed his murder conviction. In one case, United States $v$. Rees, 193 F. Supp. 849, 853 (D. Maryland 1961), the judge stated that during the search of the Rees family home, FBI agents found "a mass of obscene material, including pictures of scantily clad women with penciled drawings added showing their arms tied, etc.”]

"Prostitutes tell rape trial of torture attacks." Daily Record (Glasgow, Scotland), October 24, 2000. "Two teenage prostitutes told a jury yesterday how they had been brutally assaulted and raped after being picked up...Both claim [Defendant], 38, drove them to a house....and subjected them to a horrific and shameful sexual ordeal. The first alleged victim, a 19-year-old, said she was picked up by [Defendant]...in a white van and sexually assaulted with a gun and pole before 
being raped. She told Joanna Johnston, prosecuting: 'He tied my wrists and ankles to a bed before assaulting me.'...A second alleged victim, an 18-year-old prostitute...wept in the witness box as she claimed how she...had been sexually assaulted with a hammer before being raped by [Defendant]." [Author's note: Defendant was convicted of raping the two young women.]

"Killer 'researched perfect crime on net." BBC News (UK), October 3, 2000, http://news.bbc.co.uk/2/hi/uk_news/954596.stm. “...A jury...was told [Defendant] fantasised about raping and stabbing women and sent e-mails to others who shared his interest...In the e-mails [Defendant] allegedly referred to women as 'meat' and said fulfilling his fantasy would make him a 'true man'...[Victim]...was found...handcuffed and semi-naked in the bedroom of her home. She had suffered numerous stab wounds...Wendy Joseph QC, prosecuting, said...'Her throat had been cut with a knife a number of times. There were also quite a number of stab wounds through her breasts going considerable distance into her body.'...Ms Joseph said [Defendant] spent hours scouring the net for websites concerned with rape and violence...She said one of the sites contained stories of rape and violence towards women but she added: 'It was peppered with warnings about not acting out the fantasies.' The court heard that police discovered a number of violent e-mails which [Defendant] had written. In one, he described dragging a woman into a dark alley, raping and stabbing her through her breasts. The court heard [Defendant] had also logged on to sites about...'snuff' movies.”'

“Sex attacker's city hall deal horrifies victim." Julie Carl. London Free Press, September 9, 2000. "[Defendant], 35, a planning and building inspector for the city, pleaded guilty...to aggravated sexual assault for an attack that could have been inspired by torture porn sites he may have viewed on city time and equipment...Det. Const. Eric Potasse described the attack as among the most vicious of sexual assaults...[Victim] said she felt secure going to his house after [an event] because he'd always been loving and kind to her. But it was a very different [Defendant] once they got there. She said he handcuffed her to the bedposts, tied he legs, and repeatedly bit her...She watched him grab piercing needles from the bedside table and cried and begged him stop as he pierced her nipples and another body part. Potasse said it was the nonconsensual piercing of her body that raised the charge...to aggravated sexual assault."

“Death Sentence for Kraft Upheld." Richard Maros. Los Angeles Times, August 11, 2000, http://articles.latimes.com/2000/aug/11/local/me-2818. "Eleven years after [a]...jury convicted Randy Kraft of murdering 16 people, the California Supreme Court...upheld his death sentence...The 'Scorecard Killer' strangled his victims after drugging and sexually assaulting them...Prosecutors said they were encouraged by the court's unanimous, strongly worded decision...But they acknowledged that...more appeals at the federal level should be expected... Prosecutors suspect Kraft killed as many as 45 young men in Southern California, Oregon and Michigan...[H]e targeted hitchhikers 18 to 25 years old. Many were sexually tortured before being strangled to death with their own belts. One victim's eyes had been burned with a cigarette lighter. Another man's head was found in the waters off the Long Beach Marina...After the 13-month trial, jurors deliberated two days before sentencing Kraft to death. The trial court judge upheld the penalty, saying the killings and mutilations were beyond comprehension. 'I can't imagine doing these things in scientific experiments on a dead person, much less [to] someone alive,' said Superior Court Judge Donald A. McCartin..." [Author's note: In upholding the death penalty for Kraft, the California Supreme Court briefly described 
how each person was murdered. The opinion is at http://caselaw.findlaw.com/casupreme-court/1402694.html.]

"Man Arrested in Killings of Six Women." William Rashbaum. New York Times, August 5, 2000, http://www.nytimes.com/2000/08/05/nyregion/man-arrested-in-killings-of-six-women.html. "The police arrested a homeless panhandler yesterday in the killings of six women in Brooklyn whose deaths stirred fear among residents of Williamsburg and nearby areas...An investigator familiar with the case said DNA evidence had linked [Defendant] to the slayings, which... occurred on rooftops, in vacant lots and in apartments...In all of the killings, the women were strangled...two with their own sneaker laces, one with the drawstring from a pair of sweat pants, two with electrical cord and one with a piece of cloth, the police said. Most had arrest records for prostitution or drug-related offenses and all were found nude or partly clothed, a senior law enforcement official said. [Author's note: Defendant pled guilty to five murders.]

Commonwealth v. Edward S. O'Brien, 432 Mass. 578 (2000), http://masscases.com/cases/sjc/432/432mass578.html. "The defendant was convicted of murder in the first degree under a theory of extreme atrocity or cruelty...We summarize the facts the jury could have found...The victim...was the mother of one of the defendant's best friends...The defendant, who was fifteen years old in July, 1995, lived across the street from [Victim's family]...The defendant developed a preoccupation with the victim during the year prior to her death. He watched her closely, sometimes through a telescope from his bedroom. He...told [his best friend] that he had watched her undress...An autopsy revealed that [Victim] sustained sixty-six stab wounds and thirty-two incised wounds (length greater than width). There were numerous stab and incised wounds to her neck, and small puncture wounds under her chin. Her upper right lung had seven stab wounds which corresponded to only two exterior wounds, signifying that a knife had been thrust into the two exterior wounds more than once. There was one stab wound to her lower left lung, and two to her liver. One stab was delivered with such force that it cut her second left rib in two. There were defensive wounds on her left hand and arm. The cause of death was determined to be a loss of blood due to multiple stab wounds, most significantly to the lungs and liver... Evidence of defendant's state of mind. The judge admitted, over the defendant's objection, evidence of a front-page Boston Herald newspaper article, dated about one month before the murder, found on a bureau in the defendant's bedroom, which bore the headline: 'We're Natural Born Killers.' The article described the fascination three men had with a motion picture, 'Natural Born Killers,' and how one had boasted...after they killed an elderly man by stabbing him 27 times....[T]he judge...instructed the jury that the evidence was [offered]...'only on the simple, limited issue as to the Defendant's state of mind around the time of this incident.'... Here, the unusually high number of stab wounds inflicted was similar to the number of stab wounds inflicted on the victim described in the newspaper article. Both were cases of 'overkill." [Author's note: The Improper Bostonian (Resnek \& Szechenyi, 1997) reported that Defendant worked part time at a retail outlet that was a "combination porno parlor, variety store" and that Defendant was reportedly "a frequent visitor to the hidden room" where a "mountain of pornography" was displayed.]

“Torture Killer Heidnik Executed." Russell E. Eshleman Jr., Joseph A. Slobodzian and Glen Justice. Philadelphia Inquirer, July 7, 1999, http://articles.philly.com/1999-07-07/news/25523487_1_maxine-davidson-white-gary- 
michael-heidnik-execution. "Gary Heidnik, the 'House of Horrors' killer convicted of torturing and murdering two women in the basement of his Philadelphia home a decade ago, was put to death by injection...In a statement from his home... [Gov. Tom] Ridge said: 'Twelve years ago, Gary Heidnik kidnapped six women. For four months he imprisoned them in chains, in the filth and stench of a hole dug under his home. He raped and tortured those poor women, in ways that are too depraved and brutal to describe. He killed two of them.......At Heidnik's trial, survivors testified that after Lindsay died, Heidnik dismembered her with an electric saw, cooked parts of her body, and mixed her remains with dog food, which he then fed to the other women...In 1987, when investigators went to Heidnik's house, they were stunned to find three women naked or partly clothed chained in the basement. The survivors later testified that Heidnik not only kept them restrained in holes filled with water, but that he also periodically shocked them by dropping live electrical wires into the water. Prosecutors presented even more hideous testimony and evidence at the trial. Heidnik, they said, used a screwdriver to gouge the women's ears and played loud music to prevent them from knowing when he was in the house. The survivors said Heidnik killed [Deborah] Dudley by touching the live wires to her while she was in a water-filled pit. The jury was told [Sarah] Lindsay died while her arm was attached to a rafter in the basement."

"Feds search for victims of 'sex-torture' couple." Andy Soltis. New York Post, March 31, 1999, http://nypost.com/1999/03/31/feds-search-for-victims-ofsex-torture-couple/. "FBI agents and police are searching three western states for victims of a couple who sexually tortured - and may have murdered - women in a lakeside trailer home...Two...psychological profilers have joined the bizarre investigation of David Ray, 59, and Cindy Hendy, 39, they said. The case began...when a woman wearing only a padlocked metal collar escaped from a trailer in Elephant Butte, N.M., officials said...Ray showed the woman a badge, told her she was under arrest for prostitution and brought her to the trailer, she said. There the couple sexually tortured her and shocked her with electricity for three days before she escaped...After Ray and Hendy were arrested, another woman came forward and said she, too, had been tortured...Dozen of FBI agents have been searching...Yesterday, they seized explicit photographs from Ray's home, including one showing one of the victims restrained, her body being stretched by torture instruments, officials said." [Author's note: David Ray pled guilty to various charges and died in prison. More recently, the Daily Mail (2011, October 12) reported on an interview ten years ago with Ray: "Ray...said: 'It was a source of entertainment, to me, to create these tapes...My fantasies are not that unusual. There are approximately two million people in the United States that have, basically, the same fantasies. There's organizations. There's clubs...It's in the closet...It's not that unusual."]

Chamberlain v. State, 998 S.W.2d 230, (Tex. Crim. App. 1999), http://caselaw.findlaw.com/tx-court-of-criminal-appeals/1163837.html. “...In his second point of error, appellant claims the evidence is legally insufficient to support the jury's finding that a probability exists that appellant will commit criminal acts of violence constituting a continuing threat to society...A brief account of the facts...is necessary...Appellant lived next door to the victim, a single mother, and her five-year-old son... [A]ppellant...went next door 'to borrow a cup of sugar.' Upon gaining entry to the victim's apartment, appellant bound her with duct tape and sexually assaulted her. Appellant then shot the victim in the forehead, killing her... The State introduced evidence that appellant had attacked a fellow soldier with a knife and a woman at a shopping mall with a stun gun...In addition to this 
evidence of a violent past, the State introduced the testimony of Dr. Kenneth DeKleva, a psychiatrist. DeKleva asserted that the facts of the offense reveal a sexually sadistic, antisocial personality disorder. DeKleva noted that the crime scene revealed that the perpetrator needed to inflict humiliation, degradation and pain to achieve sexual gratification...DeKleva noted the evidence of appellant's overpowering sexual urges, i.e., that as a teenager he kept a mannequin with the crotch cut out, that he burglarized the pornography store when he found it closed and had stolen inflatable sex dolls."

"Young Prostitute's Chilling Tale of Torture, Escape." Jaxon Van Derbeken. San Francisco Chronicle, February 7, 1998, http://www.sfgate.com/news/ article/Young-Prostitute-s-Chilling-Tale-of-Torture-3013864.php. "A 19-year-old prostitute desperately begged for mercy as the man she later identified as [Defendant] inflicted blow after blow on her skull, according to the transcript of the grand jury hearing that led to his indictment...[Defendant] 54-year- old plumbing contractor... has denied involvement in the October 4 rape, torture and beating. The grand jury indicted [Defendant] in January on charges of attempted murder, assault with a deadly weapon, mayhem, torture, false imprisonment, kidnapping and false imprisonment. He also was charged with rape, sexual battery and several counts of forced sex acts. Prosecutors say they hope to consolidate the latest case with three previous sexual assault cases pending against [Defendant], who was free on bail when the attack on the 19-year-old took place in October... The victim, who has since turned 20, told the grand jury she suffered two skull fractures in the assault and underwent two surgeries requiring 74 staples and 80 stitches. She said she still feels numbness in her hands. Prosecutors said she survived only because she feigned death...[T]he man told her he wanted to kiss her and have unprotected oral sex, she said. When she refused, he tied her up and forced her to commit sex acts for 45 minutes in the back seat of his Cadillac, she told the grand jury...He told her to get out of the car so he could unbind her. But soon he was beating her again."

"Spielberg recounts fears, anguish over alleged stalker." Reuters. CNN, February 26, 1998, http://edition.cnn.com/SHOWBIZ/9802/26/ spielberg. stalker/. "Oscar-winning director Steven Spielberg on Wednesday testified that he remains deeply 'frightened' of the man accused of stalking him... [Defendant], 31, was arrested...at Spielberg's Pacific Palisades mansion and is charged with one count of felony stalking...Police have testified that [Defendant] was carrying handcuffs, duct tape and a box cutter at the time of his arrest. They said his car contained two more sets of handcuffs, razor blades - items prosecutor Rhonda Saunders called a 'rape kit.'... A police detective testified on Tuesday that [Defendant] told him he was obsessed with Spielberg and wanted to rape him. Another police officer told the court that he had found a 'shopping list' of sadomasochistic sex aids among the man's belongings." [Author's note: Defendant was convicted and sentenced to 25 years to life.]

"Private eye strangled woman 'after watching hardcore violent pornography." Caroline Sigley. PA News (UK), January 16, 1998. "A private detective pleaded guilty to murder... after a court heard that he subjected his victim to a violent sexual assault similar to scenes he watched just hours before in a hard-core pornographic film...The mother-of-one had been knocked unconscious, bound, gagged and sexually assaulted before being strangled. The Crown's case was that [Defendant], a married father-of-two and former soldier, had been at a sex party with 10 other people in which a hard-core pornographic film was viewed. A number of couples had paired off into bedrooms and [Defendant] was left alone to watch 
the video. An 18-minute sequence showed a woman having her hands chained behind her back and having her arms and legs restrained while a variety of sex acts took place...The prosecution claimed that [Defendant], sexually aroused and frustrated, had somehow gained access to the victim's home and acted out some of the things he had watched just hours earlier...He admitted the killing despite the fact that the judge...had earlier [excluded] some of the prosecution evidence - including the fact that he had watched the porn video - which means the jury would not have heard it."

“Hostage Case Suspect Linked to Other Sex Crimes." Kit R. Roane. New York Times, August 23, 1997, http://www.nytimes.com/1997/08/23/nyregion/hostage-case-suspect-linked-to-other-sex-crimes.html. "A man accused of holding a Burmese woman hostage and sexually abusing and torturing her in his Manhattan apartment was denied bail yesterday after prosecutors said he had previously been arrested in three similar cases, and raised the possibility that he was tied to additional crimes. [Defendant], 47, who has pleaded not guilty..., was involved in three other cases where women who went to his apartment were beaten, bound and forced to engage in sexual acts, Assistant District Attorney Kathleen Jones told Judge A. Kirke Bartley of Criminal Court...Ms. Jones said the charges were dropped in all three cases because the victims were too frightened to testify...A search of [Defendant's] apartment turned up more than 30 photographs of women bound or gagged. The police also found items associated with sadomasochistic sex... [Defendant] currently faces three counts of kidnapping, as well as counts of sodomy and aggravated sexual assault...A Federal complaint filed in the case states that on Aug. 8, [Defendant] forced a 31-year-old woman into his Inwood apartment, where he held her against her will, shackling her arms and legs and sexually abusing her over 10 days."

Chandler v. State, 702 So. 2d 186 (Fla. 1997), https://www.courtlistener.com/opinion/1101139/chandler-v-state/. "We have on appeal the judgments and sentences of the trial court imposing the death penalty upon appellant Oba Chandler ...For the reasons expressed below, we affirm...The record reflects that the body of [Mother] and those of her two daughters, Michelle [age 17] and Christe [age 14], were discovered floating in Tampa Bay on June 4, 1989. Each body was nude from the waist down. [Mother's] hands were tied behind her back, her ankles were tied together, and the yellow rope around her neck was attached to a concrete block. Christe's hands and ankles were similarly tied, and she had duct tape on her face or head and a rope around her neck. Michelle's left hand was free with only a loop of rope attached, her ankles were bound, she had duct tape on her face or head, and the rope around her neck was attached to a concrete block. The assistant medical examiner...determined that the cause of death for each victim was either asphyxiation due to strangulation from the ropes tied around their necks or drowning." [Author's note: The Tampa Bay Times (Andrews, 2015) reported after Chandler's execution that his DNA linked him to another murder. In addition to raping and murdering three Ohio women in $1989 . .$. , Coral Springs police now say Oba Chandler abducted, raped and strangled a 20-year-old newlywed. Using sophisticated DNA testing procedures, police are now convinced Chandler is responsible for the murder of [Victim4]..."Our victim had ligature markings on her ankles and wrists," [Coral Springs police detective Dan] Cucchi said.]

"Fugitive unit of FBI hunts man in assaults." Lisa Respers. Baltimore Sun, September 15, 1996, http.//articles.baltimoresun.com/1996-09-15/news/ 1996259057_1_elliott-fugitive-task-force.“Baltimore County police have enlisted 
the aid of the FBI's Fugitive Task Force as they expanded the search for a man accused of holding two prostitutes captive in a hidden torture chamber and sexually assaulting them...[Defendant] has been charged in warrants with kidnapping, first-degree sexual offenses and a handgun offense. The women -- ages 32 and 29 -- said they were picked up by [Defendant]...and kept shackled in the hidden basement room. The women said they were threatened with death and forced to perform sexual acts...Witnesses said both women were shackled - one in an elaborate contraption with chains holding a rubber ball in her mouth, and linked to neck, wrist and foot restraints....Elliott has a lengthy criminal record, including a conviction in the 1968 kidnapping and rape of a 14-year-old girl...He was sentenced to 60 years in prison after the girl -- who was held captive for a month -- testified that Elliott and another man...raped, beat and tortured her." [Author's note: Defendant was shot to death.]

"Williams Set to Die on Friday." Richard C. Paddock. Los Angeles Times, May 1, 1996, http://articles.latimes.com/1996-05-01/news/mn-64776_1_william-bonin. "For 17 years, Keith Daniel Williams has waited at San Quentin for his turn to die...[T] he remorseful triple murderer is about to become the fourth person to be executed in California since the death penalty was reinstated in 1978 . Williams was 31 when he shot and killed two...men execution-style in a nonsensical attempt to steal back a bad check he had written. While he was at it, he kidnapped Lourdes Meza, a 25-year-old mother of four, and took her to a secluded hill, where he shot her in the back of the head as he raped her...According to Tyson, who later testified against Williams, the killer said he had wanted to experience her "dying twitches."

“Clemency denied in Ga. execution." UPI. May 1, 1996. "The Georgia Board of Pardons and Parole...refused to commute the execution of Ellis Wayne Felker, convicted of the 1981 rape, sodomy and murder of a waitress...Prosecutors said Felker assaulted the woman repeatedly over several hours before he strangled her. According to court testimony, he bound [Victim], placed duct tape over her eyes and mouth, and then raped and sodomized her. Investigators said they also found sexually explicit photos and pencil sketches in Feller's home that he reportedly made of men and women in various sexual positions, including many that involved bondage."

“Hooker-Slay Suspect Charged." Alice McQuillan \& Corky Siemaszko. New York Daily News, October 25, 1995, http://www.nydailynews.com/archives/news/hooker-slay-suspect-charged-article-1.707474. "A mild-mannered clerk was charged yesterday with being the monster who stalked and killed two Manhattan prostitutes and sexually assaulted four other women. [Defendant], 39, regularly trolled the lower East Side and Chelsea looking for prostitutes with whom he could act out deadly bondage fantasies, cops said...When cops arrested [Defendant]..., they found a clothesline....and a notebook containing amateurish sketches of women in bondage. There also was a poem about punishing a woman who had spurned his advances, police said. At the Harlem home of [Defendant's] aunt, police found more drawings and a collection of bondage magazines...[Defendant] generally took the women to seedy hotels, where he reportedly made them twirl like a ballerina before sexually assaulting and strangling them. 'He had a ballerina foot fetish,' the source said. 'He wanted to see their feet..."'

"Policeman forced women into bondage, Court told," Suzanne Klotz. Australian Associated Press, September 29, 1995. "A former Gold Coast police sergeant was involved in sexual attacks on two women, forcing them into painful 
bondage and discipline rituals, the District Court was told...[Defendant]...was jailed for 12 years after pleading guilty to 16 counts, including deprivation of liberty, aggravated indecent assault and attempted rape. The two women were hooded, stripped, handcuffed and had nipple clamps attached before they were assaulted. One victim was also whipped...Whips, chains, a box of pornography, sadomasochism magazines, handcuffs, vibrators and a hooded mask were all seized from [Defendant's] home during a police search."

"British Serial Killer Sentenced to Life Term for Grisly Slayings," Associated Press. Los Angeles Times, September 23, 1995, http://articles.latimes.com/1995-11-23/news/mn-6430_1_rosemary-west. "One of Britain's worst serial murderers went to prison for life...protesting she was innocent of torturing and killing 10 women and girls, including a daughter and a stepdaughter...Throughout the seven-week trial [Rosemary] West blamed all the killings on her husband, Frederick West. He had been charged in the case but killed himself before being tried... The prosecution said the Wests lured the young women, many of them vulnerable runaways, with offers of rides, lodging or jobs as nannies. They were stripped, bound with adhesive tape and sexually tortured, then killed, dismembered and buried. Many were gagged to prevent them crying out. All but one of the victims were found buried at the West home..." [Author's note: In a more recent article (Woodrow, 2011) wrote:

How sad then that Fred...was a paedophile. He wasn't good at sex...and preferred the role of voyeur. He wanted to observe his young girlfriend with other men and introduce Rose to his other penchant: sadomasochism. Fred wanted to be tied up and beaten and purposefully left S\&M pornography lying around for his young mistress to see. The couple began to develop sex games involving bondage and sadomasochism, which would later become their modus operandi inflicted on their victims...Had she not met Fred it is highly unlikely that Rose would have become a serial killer but as Detective Superintendent John Bennett, who led the investigation, said recently: "The whole case was about Rosemary being sexually insatiable. There were huge quantities of pornographic material and sex objects in the house...]

Commonwealth v. Impellizzeri, 443 Pa. Superior Ct. 296 (1995), https://www.courtlistener.com/opinion/1986078/com-v-impellizzeri/. "In this appeal involving convictions for several crimes including rape and involuntary deviate sexual intercourse, we address, inter alia, the admissibility of certain sexually explicit materials. Finding none of appellant's challenges to his judgments of sentence meritorious, we affirm... History:... He drove the victim to his home, dragged her out of the car and forced her inside his house to the bedroom. He pushed the victim on the bed, removed her clothes and, using neckties, tied her right wrist to her right ankle and her left wrist to her left ankle. Once the victim was securely bound and no longer able to resist him, appellant subjected her to a series of forced, brutal indignities, including vaginal intercourse, anal intercourse and oral sex...After his vicious attack, appellant covered the victim's head with a shirt, picked her up and carried her to his basement. There, he tied her with a rope, binding all of her limbs together. The victim testified that the rope was also tied around her neck...Appellant put a gag in the victim's mouth and went upstairs...Somehow, the victim managed to free herself of the restraints...and escaped through the window... Appellant's next issue concerns the decision of the trial court to allow the 
prosecution to introduce into evidence items found at appellant's residence...During the search of appellant's home, police seized sexually explicit materials from his closet. Recovered was a publication titled 'Anal Connection,' which consisted of color photographs of couples and trios engaged in anal sex (the 'Magazine), as well as eleven 'Hustler' magazines and two videotapes depicting various sexual acts, including anal sex (the other sexually explicit materials). Prior to trial, appellant filed a motion in limine seeking to prevent the prosecution from introducing any of the items found in the closet. At argument on the motion, the Commonwealth stated that it would forego use of the other sexually explicit materials if it was permitted to use the Magazine. The court ruled in the Commonwealth's favor and the trial went forward... We conclude that the Magazine had some, but little probative value on whether the sexual activity was forced or consensual under the circumstances presented in this case...and...should not have been admitted...We conclude that...admitting the Magazine clearly was harmless."

"Bondage items found where woman was held." Doug Guthrie. Grand Rapids Press, November 29, 1994. "A search of [Defendant's] home...turned up bags and boxes of pornographic books, magazines and videotapes about sexual bondage...In the room where the woman said she escaped, investigators found a plastic sack filled with 'bondage straps, restraints, chains' and other items...The victim said her captor also used an electronic stun gun to shock her after she was bound, gagged and blindfolded and carried to the trunk of a waiting car. The woman said she was taken to a home and left alone in an upstairs bedroom. The attacker apparently left the house and the woman managed to escape."

“Stalker kept 'top 10 list' of victims." Ron Word. Associated Press, Miami Herald, July 21, 1993. “...[Defendant]...was...charged with stalking and conspiracy to commit first degree murder... [Defendant], 20, was arrested...while shopping for a...list of materials police said he planned to use to kill a woman...he was stalking...The detective said [Defendant] had discussed with a police informant...'his future plans pertaining to sexual homicide, mutilation, cannibalism, vampirism, sexual torture.' Police seized 21 boxes of evidence including writings, drawings and pornography from [Defendant's] home and car. Among the writings,...was a 'stepby-step' plan of the murder. Authorities displayed five knives...surgical gloves...surgical sponges...They also showed some drawings done by [Defendant] of mutilated or decapitated women, including one labeled 'Lust-Murder.'...'He had a top 10 list of potential homicide victims,' said [Sheriff's Detective Jim] Redmond...' It is my opinion, it has come to the point where he has graduated from his fantasy mode and was moving...to reality mode."

"Dancer Hopes Women Come Forward on Attacks." Mike Folks. Sun-Sentinel, May 9, 1993, http://articles.sun-sentinel.com/1993-05-09/news/ 93021007981 verdict-sexual-battery-seven-day-trial. "[Victim], a topless dancer who admitted becoming a prostitute to feed her cocaine addiction, wondered if a jury was believing her rape testimony...[Victim] told the jury of her armed kidnapping....and the 18 days of repeated rapes, beatings and sadistic torture she endured before her escape. 'Even other dancers told me, 'I bet you...he gets off,' [Victim] said...[A]t the end of a seven-day trial, the jurors...convicted [Defendant], 40, of armed kidnapping, armed sexual battery and 17 counts of sexual battery by physical force... [Prosecutors] said they knew they had an uphill battle...But they also knew they could support Harper`s story. They had photos showing Harper`s injuries caused by [Defendant] beating her, hitting her with a meat tenderizer hammer 
and biting the skin from her knuckles...[and] a photo of [Victim] standing on a couch as [Defendant] forced her to masturbate..."

"Man arrested after sexual bondage complaint." Associated Press. Dallas Morning News, March 3, 1992. "A man who says he is a former Fort Worth police officer is being questioned about a woman's claim that she escaped from sexual bondage in his garage...After obtaining a warrant, police searched the home of [Defendant], 43, where they found restraints, electric cattle prods, various types of sexual paraphernalia and pornographic material...[Defendant] was held Friday night on a charge of aggravated kidnapping...'The subject picked her up...and took her to his home and had sex with her,' said Sgt. Cindy Walker. 'When she tried to leave, he locked her in the garage and bound and gagged and chained her and sexually assaulted her all night long."”

“...Jury convicts [Defendant] of dismemberment slaying.” Mark T. Osler. Journal-Times, August 2, 1991, http://journaltimes.com/news/local/guilty-juryconvicts-dressler-of-dismemberment-slaying/article_e0c8f1b3-e5b0-5a84-83e95 fcc05a4dc5e.html. "[Defendant] was convicted...of first-degree intentional homicide in the 1990 dismemberment murder of [Victim]...In closing arguments, attorneys presented very different theories about [Victim's] death to a Portage County jury... District Attorney Lennie Weber...asked the jury to convict [Defendant] of an intentional killing that was motivated by his secret fascinations with homosexuality, torture and death...Weber said a blueprint for [Victim's] murder and mutilation could be found in [Defendant's] collection of male pornography, pictures and videotapes of death and torture, and literature about homicide investigations and autopsies. 'You don't accidentally kill someone and decide to dismember them in this way,' Weber said, referring to the removal of [Victim's] arms, legs, head, genitals, heart, liver and a kidney. 'He wanted to do this. He wanted to see this,' Weber said... But [Defendant's] attorney...said [Defendant] wasn't involved in the death of [Victim]..." [Author's note: Defendant's conviction was affirmed on appeal.]

"Pornography, Depicted Violence and Crime," to the Second Melbourne Criminal Justice Symposium (University of Melbourne, 3/16/91), Richard M. Reade, Prosecutor for the Queen, State of Victoria, recounted the following case:

In my opinion, the first case is a graphic example of the serious problem our community faces as a result of the hardcore pornographic material being made freely available since the early 1970s... At about 1 a.m. on Sunday the $5^{\text {th }}$ April, 1981, a young woman...was walking on the upper esplanade...A man walked up to her, pushed a knife into her ribs, and demanded her money. He then forced her at knife point into a car park where he tied her up with rope and adhesive tape...He gagged her and said, '...Just do as I say, because if you don't I will have no alternative to cut you up, especially your boobs.' He then touched her breasts and inserted his finger into her anus and vagina...

Having tied her up again and torn her clothes off, he stuffed her underpants in her mouth, placed a pillowcase over her head and pulled her to the ground. While 'squeezing her breasts like a sponge,' he had vaginal and anal intercourse with her...

Still not satisfied he commented that her stomach was 'cute,' and with that, he cut all over her stomach with a knife. He also cut her thighs and neck, telling her that if she wanted to speak to him she was to call him 'Master.' 
He took her to a nearby tree and sliced her under the breast with the knife. He again had vaginal intercourse and cut her all over her body particularly in the area of her breasts...He then cut off her right nipple saying, 'Now you won't be able to breast feed your baby.'

When this man was arrested, he was interviewed by Police and explained his strong sexual drive and why he took the rope and the knife etc. with him that night:

Because I have been reading books on bondage and I felt a strong urge to act out what was in the books. I knew it was wrong but I couldn't help myself...It's those bondage books, sex feeds on sex, that's what has done it, those rotten books...The books show women need to be dominated, and that to grab a woman off the street and tie her up and rape her isn't really wrong; and I said to her that night that I had to do it once to get it out of my system you know...'

The court was told that a large number of books and magazines on sex were found in his bungalow. They included, 'Robbed and Raped,' 'Bondage Love,' 'Kidnapped.' His counsel described 'Bondage Love' as being 'almost a blueprint of what...occurred.'

Commonwealth $v$. Scott, 408 Mass. 811 (1990), http://masscases.com/cases/sjc/408/408mass811.html. "The defendant...was convicted by a jury...of murder in the first degree. He appeals from his conviction. The evidence before the jury was as follows. The victim, a nineteen year old woman,...walked toward her boyfriend's apartment...The victim did not arrive...[T] he victim's body was found in a wooded area... A T-shirt and an oxford shirt...were tied together behind her head and used as a gag to cover her mouth. The victim's face was abraded and bruised. From the injuries, it was determined that she was struck in the face at least three times...The blows to the face rendered the victim unconscious or semi-conscious. The reduced level of consciousness made it impossible for the victim either to untie the gag or to free her tongue, which was pushed back by the gag. The victim died from a combination of head injuries and asphyxia by the gag...A few days after the defendant's arrest, a neighbor entered the defendant's apartment and saw several pornographic magazines on the floor. He noticed that the top magazine had an article about a serial killer, and he proceeded to read it. He testified at trial that the article was about a serial killer who had killed several young women by stuffing pieces of cloth into their mouths, gagging and eventually strangling his victims. Finally, the Commonwealth introduced evidence that three young women were harassed by the defendant a few days before the victim's death... The Commonwealth argues that the defendant's overtures to the three young women were relevant to show the defendant's sexual frustration and thus his plan, motive, and intent to procure a sexual encounter at the time of the murder. We agree... There is no evidence...defendant penetrated the victim...We believe...there was sufficient evidence for a rational jury to find that the defendant attempted to rape the victim...The victim...was found on her back, wearing only her skirt, with her underpants removed, her shirt ripped off, her bra unfastened, and her breasts exposed...."

"Bundy Called a Classic Case of Sexual-sadist Serial Killer." Alex Beasley. Orlando Sentinel, January 24, 1989, http://articles.orlandosentinel.com/1989-0124/news/8901240574_1_serial-killers-bundy-sexual-sadism. “...They are serial 
killers bent on sexual sadism. These psychopaths are different from the killer who murders on the command of voices or the mass murderer who kills in an outburst. The serial killer who attacks and brutalizes women is fueled by a lust that can be temporarily satisfied with each murder. Ted Bundy is a classic case, experts say. 'In my judgment, nothing sets him apart. He is the model for the sexually sadistic killer,' said Dr. Emanuel Tanay, a Detroit psychiatrist who interviewed Bundy before his trial for the murders of two Florida State University coeds. 'You have a person who functions very well. But from time to time he is driven by the need for sexual gratification.' In that respect, Bundy is much like John Wayne Gacy, who was convicted in 1980 of murdering 33 young men and boys...Researchers at the [FBI's Behavioral Science Unit] recently studied 36 prisoners who had killed at least three women at different times. The research showed...- As children, 82 percent had abnormal sexual fantasies and daydreams. As the killers reached adulthood, 81 percent continued to have sexual fantasies..." [Author's note: In a study of 36 sexual murderers (at p.30 above), FBI researchers also reported that "When...asked to rank their sexual interests, the highest-ranking activity was pornography (81\%).” John Wayne Gacy (at pp. 70-71 below) and Ted Bundy (see, http://www.focusonthefamily.com/media/social-issues/fatal-addiction-ted-bundys-final-interview) were both affected by pornography.]

Mendyk v. State, 545 So.2d 846 (Fla. 1989), http://law.justia. com/cases/florida/supreme-court/1989/71507-0.html. "Todd Michael Mendyk appeals from the sentence of death imposed upon him in the court below...We affirm the conviction and sentence. Late in the evening of April 8, 1987, appellant and a friend, [Friend], drove to a convenience store so appellant could buy a hamburger. As they approached the store, appellant said to [Friend], 'Let's grab this b---h,' but [Friend] claimed not to have taken him seriously. However, after entering the store, appellant grabbed the clerk, a woman named [Victim], led her out to their truck, forced her inside, and directed [Friend] to drive away. Taking [Victim] to a secluded area, appellant led her from the truck and began removing her clothes. Appellant tied each of her legs to the legs of a sawhorse, and sexually tortured her by several means, including inserting a broom handle in her vagina. Appellant then untied [Victim], led her to a new location, gagged her and tied her with wire between two trees with her back arched. Returning to their car, appellant and [Friend] then attempted to leave the scene. While driving along the dirt road, however...the truck became stuck.... When further attempts failed, appellant announced, 'I'm going to have to kill her,' and walked back toward the girl once more...Upon his return, appellant told [Friend] he had strangled the girl, cut down her body and dragged her into the bushes...In the meantime, police had discovered the disappearance of [Victim]...The grand jury indicted appellant for first-degree murder...

The state subsequently filed an information additionally charging appellant with two counts of sexual battery and one of kidnapping....Appellant was tried and the jury found him guilty on all counts...In the penalty phase, the state introduced into evidence a list of pornographic book and magazine titles seized by police from appellant's residence...[T]hese titles generally covered themes involving slavery, bondage, sadomasochism, deviant sexual behavior, lesbianism, anal sex, the sexual use of enemas, and 'telephone sex.'...The jury recommended death unanimously. The trial court imposed the death sentence...Appellant raises eight issues...Fourth, Mendyk challenges the trial court's decision to permit the penalty-phase jury to hear a list of titles from pornographic books and magazines seized at his home. We 
agree that this was error. The titles read to the jury had no relevance to any issue at trial. While these books and magazines were not shown to the jury, the reading of the titles unquestionably was inflammatory and of no probative value to any contested issue. Moreover, the potential confusion and unfair prejudice far outweighed any probative value, even if we assume this evidence had any relevance at all. Thus, we find that the trial court abused its discretion in permitting the introduction of this evidence...However, in light of all of the evidence presented, including appellant's confessions, we find this error harmless beyond a reasonable doubt."

"Ng's Lawyers Blame Killing Spree on His Partner." Phil Willon. Los Angeles Times, December 1, 1988, http://articles.latimes.com/1998/dec/01/news/ mn-49572. "Attorneys for accused serial killer Charles Ng tried...to blame the killing spree on Ng's alleged accomplice, Leonard Lake, whom they portrayed as a domineering, sadistic ex-Marine...Defense attorney William Kelley... opened his case after a month of prosecution testimony against Ng, 38, the San Francisco man accused of the torture-killings of 12 people in a remote cabin in Northern California's Sierra foothills...[T]he late Lake's ex-wife and two other witnesses described Lake as a mentally scarred Vietnam veteran who...developed a deviant sexual appetite that eventually spun into rape and homicide...Kelley tried to show that Lake, who committed suicide in 1985 after his arrest, preyed upon the vulnerable...Monday's testimony focused on Lake's relationships with women and how he used charm and sometimes blackmail to make them submit to his sexual fantasies, which included rough wife swapping and sexual bondage." [Author's note: Stone (2010, p. 143-144) provides the following description of Leonard Lake:

Lake was...raised largely by his grandparents-after his father abandoned the family... In his adolescence he had fantasies of enslaving and torturing women...He joined the Marines, and then became a survivalist, preoccupied with making photos of nude women-which progressed to the notion of creating 'snuff films' of dying women whom he had just strangled. In the early 1980s he teamed up with a younger man, Charles Chitat Ng... Lake and $\mathrm{Ng}$ set up a bunker in a remote part of California, to which they added a crematorium. They then waylaid and kidnapped a number of women, or couples (some with children), imprisoning them in the bunker - there to be subjected to prolonged torture, humiliation, and death, the deaths recorded on videotape as "snuff films."]

“Macabre Mystery Surrounding Death of 2 Men in Kansas City." William Robbins. New York Times, June 25, 1988, http://www.nytimes.com/1988/ 06/25/us/macabre-mystery-surrounding-death-of-2-men-in-kansas-city.html.

“...The house on Charlotte Street is a mute witness, the police and prosecutors say, to one of the most macabre mysteries this city has ever encountered, a riddle of bondage, torture, sexual abuse and death from causes yet to be explained...But no charges have been filed in the deaths of the two men...or in most of the cases of torture and abuse shown in more than 200 Polaroid photographs the police found in the house...The pictures show scenes of bondage, sexual abuse and torture, the police said. In one, another young man,... apparently dead, is shown hanging head down....in the basement...In addition, the investigators found a journal detailing the times and dates of acts of torture, sexual abuse and drug injections... The bizarre case began to unfold... when a meter reader...encountered on the street a 22year-old man wearing nothing but a dog collar...The naked man told the police he 
was hitchhiking when he was picked up by Berdella and invited to [his]...home. Once there, he said, he was knocked unconscious, bound and gagged and then tortured and sexually abused for five days...The police said the hitchhiker, whom they have not identified, told them his abuser threatened that if he did not cooperate he would be killed as other victims had been. The police then arrested Mr. Berdella at his shop and searched his house, where, besides the skull of Mr. Sheldon, they found the pictures, the torture journal, pornographic magazines...” [Author's note: Robert Berdella pled guilty to murdering several men. He died in prison.]

“Items may link [Defendant] to serial killings." Bill Moushey. Pittsburgh Post-Gazette, April 30, 1988. "Lawmen from Pennsylvania, the federal government and three other states examined sordid possessions yesterday of [Defendant]...[I]nvestigators were shown gruesome bondage books, a black leather belt with protruding nails, a vibrator, handcuffs, stretched silk scarves...an instant camera, tape, cord...[Pennsylvania State police] are investigating the 1985 rape of a Butler County nurse who was abducted after showing her home to a potential buyer...The woman was bound, gagged, whipped, raped, her hair singed and her body burned before she was thrown out of an auto...and left for dead...[Ohio Sheriff Fred Abdalla] is trying to solve the murder of Christine Campbell of Chester, W.Va. Campbell, 36, was abducted from her home...She was found bound, gagged, blindfolded and dead...'Our girl was gagged in an identical fashion to one of these pictures,' Abdalla said, pointing to a lurid scene in a bondage magazine.” [Author's note: The Butler County nurse lived to talk about her experience (Harding, 2011).

“Gays warned of 'bondage strangler.” Michael Hurewitz. New York Daily News, March 29, 1986. "Gays were warned yesterday to guard against a serial killer believed to have lured three Queens homosexuals into bondage sessions in their apartments and then strangled them. There were striking similarities in the three killings..., said Deputy Chief Joseph Borelli...He said there was no sadomasochistic play indicated, but all three victims were found loosely tied, indicating a bizarre act of sexual bondage. 'It's our opinion that they may have willingly allowed themselves to be loosely tied,' Borelli said...All were robbed.”

State v. Hunt, 220 Neb. 707, 371 N.W.2d 708 (1985), http://law.justia.com/cases/nebraska/supreme-court/1985/797-6.html. "A jury found defendant, Robert Edward Hunt, Jr., guilty of first degree murder. He was thereupon so adjudged and subsequently sentenced to death. We affirm the adjudication of guilt but vacate the sentence and remand for resentencing. THE CRIME AND ITS INVESTIGATION On the evening of April 12, 1984,...Officers Kenneth Monroe, Douglas Dekker, Rick Brahmer, and Donald Klug of the Norfolk Police Department were dispatched to defendant's Norfolk home...Officer Dekker, an acquaintance of the defendant, approached him...The defendant leaned over...and said, 'Yeah, Doug, I killed her....... Officer Dekker asked defendant if he had done anything else to the victim. Defendant replied, 'Yeah, I sexually assaulted her after she was dead. I always see them girls laid out in the pictures with their eyes closed and I just had to do it.......Defendant told Officer Chapman...that he had an urge to kill a woman and have sex with her after she was dead. He explained that he had experienced these urges in the past. On these other occasions he would gather up the cassette case, together with sex magazines and a large kitchen knife, and go 'out looking for a female to do this with, but on those occasions could not find one.'...In response to a question about why he picked this particular girl, defendant stated that...he saw a photograph of the victim on the engagement page of the Norfolk Daily News...Defendant then drove to the victim's mobile home and parked...He kept the 
home under observation for another 5 or 10 minutes while he also looked at some of the sex magazines he had brought with him... When the victim opened the door, defendant pointed the gun at her and walked in. Defendant commanded the victim to lie on the floor in the kitchen. After she complied, he tied her arms and legs with the nylon rope... Defendant then dragged the victim into the living room, where he removed a nylon stocking from his cassette case and put it around her neck, strangling her. According to Officer Chapman, defendant described the process as tightening 'down tighter and tighter trying to render her unconscious.' When she finally became unconscious, defendant...removed the victim's robe and carried her into the bedroom, where he removed his pants and masturbated, ejaculating onto her stomach....He next carried the victim into the bathroom and placed her in the bathtub, which had approximately 1 foot of water in it..."

Yeck v. State, 174 Ga. App. 710, 331 S.E.2d 76 (1985), http://www.leagle. com/desion/1985884174GaApp710 1615.xml/YECK\%20v.\%20STAT. "Defendant was convicted of rape, two counts of aggravated sodomy and false imprisonment...Certain magazines ('Submarine Sadist,' 'Rope Embrace,' etc.) seized from appellant's residence were admitted into evidence....'In the trial of sexual crimes exhibits having a tendency to show bent of mind toward sexual activity have generally been allowed into evidence'...especially in light of the victim's testimony concerning acts of bondage."

People v. Gacy, 103 Ill.2d 1, 50, 60, 62-63, 468 N.E.2d 1171 (1984), http://www.leagle.com/decision/1984104103Ill2d1_1104. "In indictments returned in the circuit court of Cook County, defendant, John Wayne Gacy, was charged with 33 counts of murder, one count of deviate sexual assault, one count of indecent liberties with a child, and one count of aggravated kidnaping...Following a jury trial, defendant was found guilty on all of the other counts...Defendant was sentenced to death...The sentences were stayed...pending appeal to this court...[D]efendant admitted he had killed approximately 30 individuals...

Jeffrey Rignall testified that one night when he was walking to a local bar, defendant offered him a ride...Defendant carried Rignall into his house...[and] then chloroformed him again. When Rignall regained consciousness, he found himself restrained on a wooden board which was suspended by chains. The board had holes in it where his arms went through and where his head was placed. Defendant, who was naked, was standing directly in front of Rignall masturbating. Defendant then grabbed Rignall's head and shoved his penis into Rignall's mouth, shouting: 'You love it, you love it,'...Rignall lost consciousness several more times, and when he regained consciousness defendant shoved an unidentified object into Rignall's rectum...[At p.50]

Edward Lynch...testified that while he was at defendant's house...defendant threatened him with a carving knife and forced him into his bedroom. Lynch overpowered defendant, and defendant became...apologetic...and talked Lynch into watching a 'stag film' downstairs. While watching the movies in the basement, defendant said, 'Let me try something,' and chained Lynch's hands behind his back. He then moved behind Lynch, forced him onto a nearby mattress, and choked him until he stopped moving... [At p.60] 
Robert Donnelly testified that... Defendant brought Donnelly into his home... [D] efendant slapped Donnelly with the back of his hand, shoved Donnelly on the couch, and grabbed his hair. When Donnelly screamed, defendant pushed his face into the couch. He then removed Donnelly's pants and anally raped him. Donnelly passed out. When he regained consciousness, defendant took him into the bathroom, shoved Donnelly's head against the wall, then placed something around Donnelly's neck and started twisting it. He told Donnelly, 'My, aren't we having fun tonight?' He then forced Donnelly's head into the bathtub, which was filled with water, and held it there until Donnelly passed out. When Donnelly regained consciousness, he discovered that his clothes had been removed and the handcuffs had been moved so that his hands were now cuffed behind his back. Defendant held Donnelly's head under water again until he passed out, and when he regained consciousness he repeated this procedure once more... When Donnelly again regained consciousness, defendant picked him up from the bathroom floor and brought him back into the room with the bar. He said, 'You're just in time for the late show' and turned on a projector and showed a gay' pornographic film on the wall of the room...He then choked Donnelly until he lost consciousness. When Donnelly regained consciousness, his hands were cuffed behind his back, his ankles were bound, and there was a gag in his mouth. Defendant then inserted some sort of object into Donnelly's rectum and he passed out. When he regained consciousness, the object that was placed in his rectum was still there.... [At pp.62-63]

Attorney General's Commission on Pornography: Final Report (1986), Part 4, Chapter 1 ["Victimization"], Subsection II.A.3. ["Battery, Torture"], http://www.porn-report.com/battery-torture.htm. "The Commission also had received several accounts from individuals who described the use of pornography in the course of physical abuse, and who attributed the type and forms of abuse to specific pornograph[y]:

A former prostitute testified before another body:

The man returned with two other men. They burned her with cigarettes and attached nipple clips to her breasts. They had many S\&M magazines with them and showed her many pictures of women appearing to consent, enjoy, and encourage this abuse. She was held for twelve hours, continuously raped and beaten. She was paid fifty dollars, or about $\$ 2.33$ per hour.

\section{A former prostitute testified:}

He stripped me, tied me up, spread-eagled on the bed so that I could not move and then began to caress me very gently. Then, when he thought that I was relaxed, he squeezed my nipple really hard. I did not react. He held up a porn magazine with a picture of a beaten woman and said, 'I want you to look like that. I want you to hurt.' He then began beating me, and when I didn't cry fast enough, he lit a cigarette and held it right above my breast for a long time before he burned me.

Another woman testified before another body:

During the time that I was held captive by that man, I was physically and psychologically abused...I was whipped with belts and electrical cords. I 
was beat with pieces of wood. I was usually forced to pull my pants down before I was to be beaten. I was touched and grabbed where I did not want him to touch me. I was also locked into dark closets and the basement...and I was often not allowed to speak or cry...I believe that part of the psychological abuse I suffered from was from the pornographic materials that the man used in his terrorization of us...

\section{Bondage, Rape, Torture and Murder: Child Victims}

"Carson City Man Sentenced to Prison for Possessing and Distributing Images and Videos of Child Pornography and Rape." Release. U.S. Attorney's Office, District of Nevada, April 13, 2015, http://carsonnow. org/story/04/13/2015/carson-city-man-sentenced-10-years-prison-childponography. "....[Defendant], 30,...pleaded guilty on July 28, 2014, to one count of distribution of child pornography and one count of receipt of child pornography... According to the court records, in October 2013, [Defendant] engaged in a series of e-mail and text message conversations with an FBI special agent who was posing undercover as an adult female interested in incest. [Defendant] provided the undercover agent with instructions on how to teach the undercover agent's fictional six-year old niece to engage in sexual activity. During the chat sessions, [Defendant] e-mailed approximately 10 images of child pornography to the undercover agent. In March 2014, a federal search warrant was executed at [Defendant's] home in Carson City, and agents recovered two cellular telephones that, upon forensic examination, were found to contain a total of approximately 6,000 images and 20 videos of child pornography. The images and videos included depictions of child rape, bestiality, sadistic or masochistic conduct, and bondage-related activities with both young boys and girls."

“Teen Jailed for 'Sexual and Sadistic' Murder." Sky News (UK), January 12, 2015, http://news.sky.com/story/1406378/teen-jailed-for-sexual-and-sadistic-murder. "A teenager has been jailed for a minimum of 25 years for the murder of a 14-year-old boy who he met online while playing video games...[Defendant], 19 , befriended [Victim] over the internet and lured him to a property...It is believed the computer engineer had bound [Victim's] wrists and ankles with duct tape before stabbing him in the neck. Following the killing, [Defendant] took pictures of his victim's body and sent them to online acquaintances...The judge, Mrs Justice Cox, said she was 'sure this murder was driven by sexual and sadistic motivation', adding that [Defendant] had 'groomed this boy over a lengthy period of time' and had 'intended to kill him'...After sentencing, it emerged that [Defendant] had faced previous allegations of rape and attempted rape in 2011, but officers investigating the case decided not to take further action."

United States $v$. Robinson, No. 13-2308 (6 ${ }^{\text {th }}$ Cir. 2015), http://www.ca6.uscourts.gov/opinions.pdf/15a0027p-06.pdf. "The government appeals, for the second time, from the noncustodial sentence imposed on [Defendant] for the possession of more than 7000 images of child pornography in violation of 18 U.S.C. $\S 2252 \mathrm{~A}(\mathrm{a})(5)(B)$. Defendant's previous sentence of one day of incarceration and five years of supervised release was held substantively unreasonable by this Court... On remand, the district court again sentenced Defendant to one day of incarceration, with credit for time served...For the reasons set forth below, we Vacate Defendant's sentence and Remand the case for reassignment and resentencing...Defendant pleaded guilty to one count of possession of child 
pornography...His prosecution arose from his paid subscription, in April 2006, to a website that allowed him access to large amounts of child pornography. This website became the subject of a national investigation by the Bureau of Immigration and Customs Enforcement ("ICE")...ICE agents identified Defendant through his credit card information...A forensic examination of Defendant's computers and only fifty of the hundred-or-so discs revealed at least 7,100 images of child pornography. These images included depictions of appalling abuse of children, including child bondage and torture, and the rape of children and infants."

“Oregon City man convicted of rape, sexual abuse of 2 sisters; faces 125 years in prison." Steve Mayes. Oregonian, December 12, 2014, http://www.oregonlive.com/oregon-city/index.ssf/2014/12/oregon city man covicted of $r$. html. “...Judge Susie Norby... found [Defendant] guilty of repeatedly forcing two young sisters into having sex with him. [Defendant], said the judge, 'is a self-confessed child molester, a sex abuser who spent years systematically stripping two vulnerable children naked, literally and figuratively...' [Defendant]...began taking sexual advantage of the girls - the daughters of a female friend - in 2005 when the children were ages 6 and 3. The mother worked long hours...and [he] had easy access to the girls, said prosecutor Bill Golden...In addition to the sexual abuse, [Defendant] hit and slapped the girls, pulled off their clothing, bound one of them with duct tape, and threatened to kill their mother if they told anyone about his violations...[Defendant] also told investigators he has a bondage fetish and had hired prostitutes to indulge his interests. He also once went online and tried to hire a sex slave, according to court testimony."

"GTA man fighting extradition to U.S. over online 'sextortion." Sam Pazzano. Toronto Sun, September 28, 2014, http://www.torontosun.com/ 2014/09/28/gta-man-fighting-extradition-to-us-over-online-sextortion. "A Toronto-area medical student is fighting extradition to the United States 30 months after being charged with the online 'sextortion' of two teenaged American girls...[Defendant], 29, who was originally arrested on March 22, 2012, is accused of using 'Skype chat' to coerce a 17-year-old Virginia Beach girl to sexually abuse her younger sister. Superior Court Justice Mary Lou Benotto condemned the alleged acts as 'sadistic, sexualized conduct with children which verges on torture,' when she denied him bail in August 2012. 'The facts alleged ... are horrific,' said Benott...[Defendant] is accused of directing his victims to commit acts as he watched on a webcam...for his 'prurient, voyeuristic pleasure,' said Superior Court Justice Ken Campbell, who ordered [Defendant's] extradition in May 2013... Now his prominent Toronto lawyer, Eddie Greenspan, says he has launched appeals to the Ontario Court of Appeal challenging the extradition. No date has been set for the appeal....If convicted in a U.S. court, he faces the prospect of a 20-year minimum sentence for making child pornography. The local charges were withdrawn to enable the extradition to proceed...He allegedly recorded images of the older sister exposing her breasts and then, at his direction, sexually assaulting, gagging, tying up and beating her 13-year-old sibling with a hair brush in their Virginia Beach bedroom....[Defendant] also vowed that the girl would be 'raped' outside her school and that he'd transmit explicit images to her parents if she and her sister didn't perform sadistic sexual acts to his satisfaction, court heard. Their ordeal lasted 70 minutes until an older sister discovered them naked and cowering beside their bed, court heard."

“The strange saga of abducted Amish girls and their alleged captors' 'master-slave' relationship." Gail Sullivan. Washington Post, August 19, 2014, 
http://www.washingtonpost.com/news/morning-mix/wp/2014/08/19/thestrange-saga-of-abducted-amish-girls-and-their-alleged-captors-master-slave-relationship/. “...[A]s dusk settled over...a small Amish farming community near the Canadian border, a white sedan...drove away with two girls, aged 12 and seven...When the family realized the girls...were missing, they contacted police.... On Thursday night...word came that the girls had been found... The girls were questioned by police...leading to the arrest of [male Defendant], 39, and [female Defendant], 25, who both live and work in St. Lawrence County...The next day, St. Lawrence County District Attorney Mary Rain said the girls had been sexually abused...Since then, more disturbing details have emerged. Rain told a local TV station...there are at least three more victims...Rain also said the [Amish] girls were allegedly shackled together while held captive, and that recording equipment was present during their assault. Fox28 WNYF reported [male Defendant] was in the process of building a soundproof room. [The female Defendant's] attorney, Bradford C. Riendeau, had earlier revealed the couple...had a sadomasochistic sexual relationship. 'You've heard of '50 Shades of Grey'? 'This was the '51st Shade of Grey," he told a local news station...Riendeau described [female Defendant] as a young woman...who said she'd been under [male Defendant's] control for a long period of time. 'She appears to have been the slave and he was the master,' Riendeau told the New York Times.” [Author's note: Both Defendants plead guilty to various crimes (O’Brien, 2015, May 8). The Syracuse.com (O’Brien, 2015, May 8). also reported:

The six victims were forced to engage in sex acts with [Defendants] while the couple filmed them, [Assistant U.S. Attorney Lisa] Fletcher said. Some of the videos the couple took were more than an hour, Fletcher said. They sometimes dressed the victims in black negligees and fishnet stockings, she said. In one video, they made the victim wear a black studded collar, Fletcher said. The Amish sisters, ages 6 and 11, were the only victims [Defendants] kidnapped, Fletcher said. The other four victims were known to them...]

"'Violent porn was to blame for our girl's murder': Parents of teenager
who died in 'fantasy photo shoot' speak for first time...." Andy Dolan. Daily Mail (UK), July 6, 2014, http://www.dailymail.co.uk/news/article2682650/Parents-blame-violent-porn-murder-daughter-17-Couple-tell-angereasy-extreme-content-online.html\#ixzz37aD8P0FZ. "The parents of a teenager murdered by a friend who was obsessed with violent internet porn told yesterday of their anger at how easy it is to find extreme content online. Georgia [last name omitted], 17, agreed to pose for [Defendant] with a rope around her neck for a 'fantasy photo shoot', but he left her hanging and took photographs of her as she died. Yesterday, her parents...spoke for the first time about the role extreme pornography played in their daughter's murder. They said [Defendant]...had been viewing depraved acts online even as their daughter, who attended college with him, walked to his home 90 minutes before she died...Last month, it was revealed Devon and Cornwall Constabulary will investigate the West Mercia force's handling of a previous inquiry into [Defendant] in 2008, when he tried to strangle another teenage girl lured to his house under the pretence of a photo shoot. He was given a caution, despite police discovering doctored pictures of the victim with a noose around her neck.” 
"[Defendant] sentenced to death for [Child's] murder." WRAL.com, June 6, 2014. http://www.wral.com/richardson-sentenced-to-death-for-teghan-skibas-murder/13536926/. “...The jury took only an hour last week to convict [Defendant] of first-degree murder, first-degree kidnapping, first-degree sexual offense of a child and felony child abuse in [Victim's] death. She died from a fatal head wound three days after he took her to a...hospital, claiming she fell off a bed...But the state said the 144 wounds, including 66 bite marks, on the girl's face and 40-pound body were not the result of a fall but the work of an 'extremely wicked,' 'shockingly evil' and unremorseful man who 'perverted the laws of nature' and 'desecrated her body' when he sexually abused [Victim] and killed her...During the lengthy trial...the defense maintained that [Defendant] never meant to kill [Victim]...[Assistant District Attorney Greg] Butler disagreed, describing the injuries and the punishment that he said the girl must have endured - including being whipped numerous times with a frayed electrical cord, having a nail pried off her finger, having her arms broken and suffering severe trauma to her genital and anal areas. 'Is he mentally ill or just plain mean? Just plain cruel? Just plain sadistic?' the prosecutor asked."

"Broward pilot gets four years in prison for child porn possession." Paula McMahon. Sun Sentinel, April 9, 2014, http://articles.sun-sentinel.com/2014-04-09/news/fl-pilot-child-porn-20140409_1_massacre-young-

children-christopher-holmes-federal-prison. "A Broward County pilot was sentenced to four years in federal prison...for possession of child pornography photos - showing children as young as 6 bound and gagged - on his laptop computer. The investigation...began when federal agents uncovered online chats between [Defendant] and another man discussing - in theory - committing sexual assaults on children...A forensic analysis of his computer turned up several child porn photos, including one that showed what appeared to be 'a dead child covered with lacerations and feces,' prosecutor Corey Steinberg said. The search also turned up a more recent online chat log...that included [Defendant] describing 'in detail his desire to torture, rape and then massacre young children at a school,' records show."

"Porn addict jailed for sharing 'sickening' child torture image." Exeter Express and Echo (UK), March 31, 2014, http://www.exeterexpressandecho.co.uk/Porn-addict-jailed-sharing-sickening-child/story-20886552-detail/story.html. "A pornography addict has been jailed for swapping vile images of extreme child abuse with fellow paedophiles around the world. [Defendant] sent pictures and movies which showed children being tortured and raped...Police found he had sent hundreds of images all around the world by e-mail and through peer to peer file sharing sites including 128 which showed rape or sadism. [Defendant], aged 54,...admitted 12 counts of distributing indecent images of children and 15 of making or possessing them...Mr Jonathan Barnes, defending, said there had been no commercial element and the offences arose out of an 'addiction' to pornography which he is keen to address through treatment."

"...Inside British cannibal's torture dungeon where he planned to eat children." Christopher Bucktin. Mirror (UK), September 12, 2013, http://www.mirror.co.uk/news/world-news/geoffrey-portway-inside-britishcannibals-2267126. "Shocked US police uncovered the evil lair after a two-year crackdown on paedophiles led them to the British-born pervert's home in Worcester, Massachusetts. They found the place strewn with indecent images of children - and a fully equipped 'torture chamber.' FBI pictures show how he had built 
a staircase leading down to a hidden, sound-proof cellar. Inside was a 'child-sized homemade coffin' covered in wire mesh and fitted with padlocks. It had six metal rings inside to act as restraints. Alongside the cask was a steel cage...It, too, was fitted with locks. Investigators also found bondage equipment, knives, handcuffs, castration tools, butchery equipment, two large freezers and disposable scalpels. [Defendant] has already pleaded guilty earlier this year to plotting to kidnap a child and to distributing and possessing child pornography...Federal agents began investigating the pervert in 2012 after linking him to an internet chat room obsessed with cannibalism and child rape. He would trade sick images and videos of youngsters being horrifically abused."

"NY man indicted in carjacking rape, killing." Associated Press. April 10, 2013, http://www.denverpost.com/rawnews/ci_22994672/ny-murder-rape-suspect-faces-trial-child-porn. "A New York woman who'd just seen her 10-year-old daughter raped during a carjacking was stabbed to death during a struggle that allowed the child to escape and get help...Onondaga County District Attorney William Fitzpatrick said 29-year-old [Defendant] was trying to use cable ties to bind the woman to a headrest in her car when she fought back and shouted for the girl, whose hands were tied behind her back, to bolt from the car...Authorities said [Defendant] had hours earlier removed and quickly reassembled an electronic bracelet so monitors didn't immediately realize he'd taken it off. He was ordered to wear the device as a condition for being released from jail after his arrest in January on federal child pornography charges. Fitzpatrick said some child porn [Defendant] possessed included scenes similar to the attack on the mother and child...A federal grand jury indicted him last month on one count of receiving and five counts of possessing child pornography." [Author's note: Defendant pled guilty to first-degree murder and predatory sexual assault and to federal child pornography charges. The County District Attorney William Fitzpatrick said that Defendant "had a fascination with violent pornography, which may have been a factor in the vicious attack" (Guse, 2013, July 17)].

"Sammamish man faces child porn charges." Levi Pulkkine., seattlepi.com, September 23, 2012, http://www.seattlepi.com/local/article/ChargeSammamish-man-a-caught-sex-photo-of-3884617.php. "A Sammamish man is behind bars following allegations he was caught with an extensive collection of child porn, including one image of a naked girl who may have been killed. King County prosecutors contend [Defendant] collected hundreds of videos showing infants, toddlers and pre-adolescents being raped and tortured...Describing the severity of [Defendant's] alleged offense, Senior Deputy Prosecutor Cecelia Gregson said in court documents that one of the images found in his home depicted a 'lifeless appearing toddler with a plastic bag tied over her head.' 'The specific sexual interest... involves the torture and sadistic abuse of pre-pubescent children...,' Gregson told the court."

"Saratoga Springs man gets 14 years in prison for child porn." Jim Dalrymple. Daily Herald, July 26, 2012, http://www.heraldextra.com/ news/local/crime-and-courts/saratoga-springs-man-gets-years-in-prison-forchild-porn/article_f13ff40b-bc2d-52c2-bd70-78dc09a02300.html. "A kiddie pornmonger who peddled in sadistic child rape images...was sentenced to 168 months in federal prison for his conviction on one count of distributing child pornography...Prosecutors believe [Defendant] had more than 600 images of child pornography on his computer. He reportedly used peer-to-peer networks to share the images with as many as 153 other people. In court documents, assistant U.S. 
Attorney Carol Dain described...the material as depicting 'sadistic images of prepubescent children' being raped and tortured."

"Gore killed 6 women, but targeted more than a dozen for "kidnap, rape, court files show." Melissa E. Holsman. TCPalm, April 9, 2012, http://www.tcpalm.com/news/gore-killed-6-women-but-targeted-more-than-afor. "On the eve of his death penalty trial for the 1983 abduction, rape and murder of a Vero Beach High School senior, David Alan Gore told authorities what they had long suspected: Lynn [], 17, wasn't his first killing. She was his sixth, Gore, then 29, confessed to prosecutors...Most were sexually assaulted, some were tortured and others were dismembered...The grisly discoveries resulted in Gore pleading guilty to murdering Orlando teenagers Barbara [] and Angelica [], both 14; California resident Judy [], 35, and Hsiang [], 48, and her daughter, Ying [], 17..." [Author's note: Vernon J. Geberth (2010) describes each murder in some detail and describes Gore as a "psychopathic sexual sadist who enjoyed... sadistically murdering" his victims.]

“...Child porn evidence the jurors never heard." Raveena Aulakh. Toronto Star, May 11, 2012, http://www.thestar.com/news/crime/2012/05/11/tori_stafford_trial_childporn_evidence_thejurors_never_heard.html. "In early 2009, someone named Mychol googled 'underage rape,' 'real underage rape'...on his laptop. Between Jan. 25 and April 7, 2009, he also searched keywords like 'real rape,'...Mychol was [Defendant]...Tori [] disappeared on April 8, 2009. The evidence found in the Internet searches was never presented to the jury...[Defendant, 31] has pleaded not guilty to the abduction, rape and murder of 8-year-old Tori. Justice Thomas Heeney found that [Defendant's] Charter rights were violated when investigators did a forensic search on his laptop without a warrant...Heeney also said the Internet searches would be prejudicial... [M]ore...was kept from the jury...Investigators found child pornography...[and] uncovered 13 women who reported that [Defendant] had a penchant for sexual choking...[T] he jury also never heard that on March 28, 2009, Rafferty downloaded Gardens of the Night on his laptop - a little-known Hollywood movie about the abduction of a pretty blond girl...Heney ruled that the film's 'prejudicial impact outweighs its marginal probative value.'...[H]e also pointed out that the little girl's abduction in the movie was carefully planned, while...Tori was randomly plucked from the street." [Author's note: Defendant was found guilty on all counts.]

"Sadistic pair lure girl to night of horror, court told." news.com.au, December 9, 2011, http://www.news.com.au/national/sadistic-pair-lure-girl-tonight-of-horror/story-e6frfkvr-1226218475764. “A...couple lured a 13-year-old girl to their home where they raped, tortured and degraded her before the wife attempted to murder the girl, a court heard Friday... [P]rosecutor Michael Byrne, SC, took nearly 40 minutes to detail the offences the couple inflicted on the crying and terrified girl who was a friend of the woman's daughter...Byrne said it had been a sadistic and degrading attack on a vulnerable girl which lasted 14 to 15 hours...The man, 42, and the woman, 33, jointly pleaded guilty to 30 charges including 13 of rape, seven of indecent treatment of a child under 16, three of assault occasioning bodily harm while armed, common assault, torture, wounding, stupefying to commit an offence, making child exploitation material, deprivation of liberty, and taking a child for immoral purposes. The woman also pleaded guilty to attempted murder...He said the girl was lured to the house and when she arrived...a knife was held to her throat...Mr Byrne detailed how for the next 14 to 15 hours the girl was subjected to rape and degrading treatment, which was photographed and 
filmed. Mr Byrne said...the woman had gone 'crazy' and tried to strangle the girl with a rope..."

"Man sentenced to 97 months in Federal Prison for Possession of Child Pornography." Release. U.S. Attorney for Southern District of Miss., October 11, 2011, http://www.justice.gov/archive/usao/mss/press/OCTOBER2011/boyinton \%20sentencing.pdf. "[Defendant], 32,...was sentenced in U.S. District Court today to serve 97 months in federal prison for possession of child pornography...A federal search warrant was executed at [Defendant's] apartment in August 2009, where a laptop computer and thumb drive device, along with other electronic evidence, was seized...The forensic examination revealed numerous images of child pornography that were graphic, sadistic and horrific. The digital evidence included videos depicting adults having sexual intercourse with babies, toddlers, and young girls, and animals engaging in sexual contact with young children. Many of [Defendant's] images of child pornography show children being tortured, chained and raped."

"Serial killer Clifford Olson dies," CBC News, September 30, 2011, http://www.cbc.ca/news/canada/serial-killer-clifford-olson-dies-1.1110039. "Serial child killer Clifford Olson, who pleaded guilty to murdering 11 children in 1982, is dead...Olson's victims were all between 9 and 18 years old...It was Christmas Day 1980 when the body of 12-year-old Christine Weller was found, strangled and stabbed. The young girl from Surrey, British Columbia, was the first of his 11 known victims. He reportedly lured them with the promise of a job, and then plied them with alcohol and drugs. He tortured them, sexually assaulted them, killed them and then dumped their bodies...Olson also wrote book manuscripts, and was allowed to make a series of videotapes in prison. In them, he described what he did to his victims, including driving nails into their heads and asking them how it felt."

“Child Pornography Defendant Sentenced to 45 years in Jail." Release, U.S. Attorney's Office for Western District of Penn., June 23, 2011. http://www.fbi. gov/pittsburgh/press-releases/2011/child-pornography-defendant-sentenced-to45-years-in-jail. "A former resident of Erie, Pennsylvania has been sentenced in federal court to 45 years in prison and lifetime supervised release on his conviction of violating federal laws relating to the sexual exploitation of children...According to information presented to the court, [Defendant]... possessed, received, and transported numerous images of child pornography on two computers in his home. The investigation began when the FBI received an anonymous tip regarding [Defendant's] efforts to facilitate the travel of a mother and her 4-year-old daughter from New Zealand to Erie so that [Defendant] could engage in sex acts with the minor female...[T]he FBI then searched Noyes home and seized two computers containing numerous images of child pornography and obscene material...Prior to imposing sentence, Judge McLaughlin...stated that 'the overwhelming evidence presented at trial revealed that Noyes is a predatory pedophile and sadist with an interest in the sadistic brutalization and torture of children."

"Alleged pimp faces life in prison for raping, torturing women." Will Bigham. Inland Empire Courts, April 1, 2011, http://www.insidesocal.com/iecourts/2011/

04/01/alleged-pimp-faces-life-in-pri/. "An alleged pimp stands accused of committing numerous crimes against a 17-year-old girl and a 30-year-old woman who police believe he was grooming to work as prostitutes for him. [Defendant], 38 ,...allegedly raped both victims and tortured them by burning them with a hot iron...[P]rosecutor, Deputy District Attorney Karen Schmauss, said today that 
[Defendant] has been convicted of similar acts against women in the past...The 17year-old girl told police she... and [Defendant] had consensual sex twice in Ontario before he took her to Anaheim with a prostitute...According to Officer Ryan Ronveaux, one of [Defendant's] reasons for making the trip was to teach the 17-yearold about the prostitution trade... While the girl and [Defendant] were in Anaheim, he allegedly used pliers to pinch one of her nipples and threatened to harm her and her family. He later forced her to have sex...'You better make me happy, or your kids are going to get hurt,' [Defendant] told the girl, who has two children, according to Ronveaux's testimony. Later during their trip to Anaheim, [Defendant] became angry at the girl when he saw her talking to another pimp, Ronveaux testified. "He plugged a hair straightener into an electrical outlet and heated it up," the officer testified. '... He proceeded to apply the hot straightener to the victim's pubic area."

"Horror of Paul Bernardo crimes continues to haunt Fifteen years after Paul Bernardo was found guilty of rape and murder of teenage girls...." Jim Rankin. Toronto Starr, September 4, 2010, http://www.thestar.com/news/insight/2010/09/04/horror of paul bernardo crimes continues to haunt.html. "...[F]ifteen years ago this week, a jury in Toronto found Paul Bernardo...guilty of torturing, raping and killing teenagers Kristen French and Leslie Mahaffy...His wife and accomplice Karla Homolka was already serving a 12-year sentence for manslaughter for those two deaths, and for that of her younger sister Tammy, whom she drugged and served up as a sex gift to Bernardo and [who] died after choking on her own vomit. Today, Kristen, Leslie and Tammy - aged 15, 14, and 14 at the time of their deaths - have been gone longer that they were alive...Fifteen years on, having personally...covered court proceedings, I have mercifully forgotten...But there are moments that will forever stay in the mind... On the eleventh day, the torture and rape videotapes tapes, recorded by Bernardo and Homolka, began. They'd be played over and over again...Justice Patrick LeSage decided jurors would watch and hear, while those in the public gallery, including the press and families, need only hear the audio only. Like other colleagues who covered the trial, I am thankful for that. Yet, the screams stay with you. I often wonder how those who had to also watch have fared. It was searing and raw and many cried in court, including journalists. I didn't. Not yet...The [jury] took just over eight hours to find Bernardo guilty...It was pandemonium afterward...For me, it sank in that day...I cried for the first time...the following month, and it is the only time I have cried while on the job. I was at Debbie Mahaffy's home....and had finished a long interview with her...I'd admired how...really, that she had dealt with everything. To sit with her in her home and listen was a privilege. I rose to say goodbye and felt my knees tremble. I gave her a hug and began to cry. She kept the hug going until I managed to stop." [Author's note: In an earlier article about these crimes, Steed (1995) had this to say:

In the world of pornography, he's a stock character: a sexual sadist who developed an appetite for porn as a teenager, whose behaviour escalated from using it to doing it...He is one of us, a product of this culture, conditioned in the shadowy underworld of porn, where the dark side of the human psyche emerges in sadomasochism and sexual torture...[Defendant's] trial was, in part, a trial about pornography...Produced and directed by [Defendant] starring [Defendant]..., the videos documented acts of sexual violence and degradation that included urinating on victims...[Defendant], 31, has been characterized as a monster, yet his behavior...is ordinary 
stuff in terms of hard-core pornography. The dog collars, the death threats, the ropes around the throats of his victims; the excitement he experienced inflicting pain, videotaping his victims' suffering so he could relive it...these are the common themes of the sexual sadists who represent the "leading edge" of the...porn industry...Detective Staff Sergeant Bob Matthews of the Ontario Provincial Police... says, "there's been an explosion of violence and degradation in porn videos and on the Internet...There's a huge market for this stuff"...In Matthews' experience, "the guys who get into the violent, degrading porn get addicted...it dominates their lives...and some of them start doing what they see."]

"Elizabeth Smart Says Brian David Mitchell Raped Her Daily." Emily Friedman \& Barbara Pinto. ABC News ("Nightline"), October 1, 2009, http://abcnews.go.com/US/elizabeth-smart-testifies-raped-kidnapper/story? $\mathrm{id}=8724302 \&$ singlePage=true. "Elizabeth Smart testified today she was raped 'on a daily basis up to three or four times' by [Defendant]...who allegedly kidnapped Smart....and held her captive for nine months months...[Defendant] kept Smart from escaping by attaching chains around her ankles and tying them to nearby trees...Throughout her captivity, Smart said she was consistently given alcohol and drugs by [Defendant] and was shown pornography...Smart was 14 when she was taken from her home...Smart recalled the details of the night she was taken from her bedroom. 'A man broke into my house and held me at knife point...,' said Smart. According to Smart, [Defendant]...whispered to her to stay quiet and that if she disobeyed he would kill her and her family." [Author's note: Mitchell was found guilty of kidnapping and unlawful transportation of a minor across state lines for illegal sex.]

“[Defendant's] LSD trips and sexual fantasies: How did [Victim] survive?" Edecio Martinez. CBS News (“Crimesider"), September 1, 2009, http://www.cbsnews.com/news/phillip-garridos-lsd-trips-and-sexual-fantasieshow-did-jaycee-lee-dugard-survive/. "[Defendant] spent the 1970s on one debauchery after another...Then in 1976, he found a new way to indulge his twisted sexual fantasies. He kidnapped a woman..., handcuffed her, took four hits of acid and raped the victim in a storage unit...The investigator in the case described the storage unit as a 'sex palace,' with various sex aids, pornography, stage lights and wine. The...rape case provided an early glimpse into the criminal exploits of [Defendant], who allegedly snatched 11-year-old [Victim] from a bus stop and held her captive for 18 years, fathering her two children, before being arrested this week...A retired Reno police detective assigned to the first criminal case said that [Defendant] indicated he preferred sex by force after confessing the crimes to him...'I asked him after he confessed why he did it, and he said it was the only way he could get sexual satisfaction. I think he had to use force to get sexual satisfaction,' [the detective] said."

"Illinois man sentenced to 20 years for child pornography." Release. U.S. Immigration and Customs Enforcement," August 21, 2009, https://www.ice. gov/news/releases/illinois-man-sentenced-20-years-child-pornography. "An Illinois man who distributed child pornography containing graphic images of rape, sadism and torture was sentenced to 20 years in... prison. This sentencing resulted from an investigation conducted by U.S. Immigration and Customs Enforcement (ICE)...Evidence presented during the trial demonstrated that the defendant's child pornography included images of sadistic behavior, rape and torture. 
Evidence was also presented that the defendant distributed child pornography through a peer-to-peer, file-sharing network."

“Brisbane man jailed over 'worst kind' of child porn." Jason Rawlins. $A B C$ News (AU), August 3, 2009, http://www.abc.net.au/news/2009-08-03/brisbaneman-jailed-over-worst-kind-of-child-porn/1376890. "A Brisbane man has been jailed for possessing what has been described as the worst kind of child pornography. [Defendant], 40, pleaded guilty...to two counts of possessing child exploitation material. Prosecutor Philip McCarthy told the court, [Defendant] was arrested last year after police raided his home. They uncovered a computer hard drive and 11 DVDs with more than 30,000 images and videos of children being abused. McCarthy says the material included infants being forced to engage in acts of sadism, torture and bestiality."

"Jurors in Idaho murder case cry at videos of torture, sexual abuse...." Rebecca Boone, AP. seattlepi.com, August 21, 2008, http://www.seattlepi.com/local/article/Jurors-in-Idaho-murder-case-cry-at-videos-of-1282951.php. "Jurors cringed, cried and some desperately looked away as they were shown a series of deeply disturbing and graphic videos taken by a convicted child killer as he tortured, sexually abused.... 9-year-old boy. Federal prosecutors showed the video as part of their efforts to persuade the jury to recommend the death penalty for [Defendant]. He kidnapped the boy, [Victim1], and his sister, [Victim2], in May 2005 after murdering their older brother, their mother and her fiancé. The two young children were taken deep into the Lolo National Forest, where they endured weeks of horrendous abuse at the hands of [Defendant]. [Defendant] ultimately shot the boy point-blank in the head while his sister, then 8 , watched...The video and photos taken at the cabin show Duncan forcing the boy to perform a sex act, whipping him with a belt and hanging him with a wire noose until the boy passed out. 'The devil is here, boy, the devil himself. The demon couldn't do what the devil sent him to do, so the devil came himself,' [Defendant] yells in one video. 'The devil likes to watch children suffer and cry.'...[Defendant], a convicted pedophile..., has pleaded guilty to federal and state counts including murder. The federal jury is considering the death penalty..."

"Lost Boys of Texas." Mara Bovsun. New York Daily News, ("The Justice Story"), June 28, 2008, at http://www.nydailynews.com/news/crime/lost-boystexas-article-1.292434. "In the early 1970s, roughly 1 million young people per year went missing in the United States. Many were runaways who landed in communes, or carved out new lives and became strangers to their families. Most eventually wandered back home. Twenty-seven of them ended up as corpses in makeshift graves all around Texas, victims of Dean Arnold Corll, the worst mass murderer the nation had ever seen. At the time investigators doubted that they'd ever name all the victims... Corll, 33, was known in his community as a polite, quiet, neat bachelor... He seemed to have a way with teenage boys, especially troubled ones...But...it was all a façade, a mask that hid the real Dean Corll, a sadistic murderer who had been luring boys to their deaths for years...It would have been easy to dismiss [a 17-year-old accomplice's] fantastic tale as a lie...Then police took a good look around Corll's home, and the image of the kind candy man started to melt. There were knives, guns and sex toys. The bedroom housed a weird contraption: a long plywood board with handcuffs on one side, ropes on the other. That...was known as the 'torture board.' It was where Corll tied up young boys for terrifying episodes of molestation and murder..." [Author's note: For a detailed account of this man's crimes, see Hollandsworth, (2011, April). 
"Murder down the freeway." Mara Bovsun. New York Daily News, March 25, 2008, http://www.nydailynews.com/news/crime/murder-freeway-article1.2647 43 "...Every day, you would see them out there, along the highways. Slender, tanned, shaggy-haired girls and boys, some with surfboards, some in bright Tshirts, all with smiles on their faces and thumbs out, hitching a ride. But starting in the summer of 1979, these golden youngsters all but vanished. It was the year of the Freeway Killer. A horrifying string of murders left no doubt that a deranged murderer was on the loose, plucking his victims off the road. The dead were all male - kids going for a bike ride or teenagers and young men heading for the beach, the bars or adventure. The first was [Victim1], a 17-year-old German exchange student. He was last seen hitchhiking along the Pacific Coast Highway on Aug. 5, 1979. His naked corpse was found in Malibu Canyon, stabbed nearly 80 times, with a nylon rope around his neck, a few days later. Next, on Aug. 27, was [Victim2], a 15year-old from Hollywood. Police found his mutilated body in a Dumpster. His throat had been slashed, and he had been strangled and raped. The same fate met [Victim3], 17. On Sept. 9, he was heading for the movies on his bicycle. Three days later, his body was found, sodomized and mutilated in much the same way as the others. Some of the dead...were just kids. [Victim4] 12, was waiting for a bus to take him to Disneyland in early March 1980, when he was snatched, then bludgeoned, strangled and tossed in the trash. Many were strangled with their own Tshirts, a metal bar used to tighten it around their necks, while a few were tortured. Most had been sexually assaulted...The body count looked as if it was likely to continue to rise, until cops caught a lucky break...[Defendant] first faced a jury in Los Angeles, who found him guilty of 10 murders. In a second trial...he was convicted of four more, and sentenced to death."

"S.C. man gets 421 years in bunker case." Bruce Smith, Associated Press, USA TODAY, September 19, 2007, http://usatoday30.usatoday.com/news/nation/2007-09-18-372361620_x.htm. "A man who admitted to kidnapping a 14year-old girl and holding her for more than a week in an underground bunker, raping her daily, was sentenced...to 421 years in prison for a crime the judge called 'repulsive.' [Defendant] pleaded guilty...moments before his trial, to charges of kidnapping and 10 counts of criminal sexual conduct, one for each day prosecutors said he held the girl captive a year ago... The teen was rescued after she got hold of [Defendant's] cell phone and sent a text message...[Defendant] detailed the crime in writings done from his jail cell, which prosecutors quoted...[Defendant] said he posed as a police officer when he kidnapped the girl as she walked home from her bus stop. She was chained to a beam in the tiny bunker and raped daily, authorities said. 'Like a predator, I waited on one lonely stray to walk by,' prosecutor Barney Giese read from [Defendant's] manuscript."

"DCF worker from area admits to child porn." News-Press, July 20, 2007. "A Florida Department of Children and Families investigator...pleaded guilty to possession of child pornography... [Defendant]...sent nude pictures of himself and pictures of bondage equipment in his 'dungeon'...[to an undercover FBI] agent...posing as a 13-year-old girl in an Internet chat room..." [Author's note: Another press account (Gillespie, 2007, October 12) reported that Defendant had spoken to the undercover agent about "meeting to have sex and to make her his 'slave."']

"Former Va. ACLU Head Pleads Guilty in Child Pornography Case." Jerry Markon. Washington Post, June 2, 2007, http://www.washington post.com/wp-dyn/content/article/2007/06/01/AR2007060101882.html. 
former Arlington County youth sports coach who once headed the Virginia ACLU pleaded guilty yesterday to charges that he purchased child pornography so graphic that prosecutors called it 'sadistic.' [Defendant], 51, admitted that he accessed more than 850 pornographic images of children as young as 4 , including a six-minute video depicting the sexual torture of children...[Defendant's] plea agreement...said the images he downloaded showed 'sadistic or masochistic conduct.' U.S. Magistrate Judge Theresa C. Buchanan...described the material...'the most perverted and nauseating and sickening type of child pornography' she has seen in 10 years on the bench."

"Man Sentenced in Online Child Porn Case." Hartford Courant, February 14, 2007, http://articles.courant.com/2007-02-14/news/0702140646_1_childpornography-pornography-images-sentencing. "A 42-year-old city man who admitted to federal investigators that he had received and distributed child pornography via the Internet...has been sentenced to five years in prison...According to court documents and statements made in court, in March 2005 an FBI agent who had assumed the online identity of a child pornography distributor identified the screen name 'PERVINPIG' as being associated with the e-mailing of child pornography images...FBI agents... seized [Defendant's] computer...Several of the images that [Defendant] possessed portrayed sadistic or masochistic conduct or other depictions of violence, including the raping of young children, [U.S. Attorney Kevin] O'Connor said. 'This defendant used the Internet to trade some of the most disturbing images of infant and toddler child pornography and sexual abuse that law enforcement has seen," O'Connor said."

“Man Gets Prison Term: 18-year Sentence for Raping Girl.” Staff writer. Hartford Courant, September 9, 2006, http://articles.courant.com/2006-0909/news/0609090465_1_mr-judkins-sexual-assault-abuse. "An Ellington man was sentenced to 18 years in prison Friday after pleading guilty to repeatedly raping a young girl over several years. [Defendant], 38, admitted that he began sexually assaulting the child when she was 5 years old. The abuse continued until last year. The child is now 11...As part of a plea bargain..., [Defendant] pleaded guilty to two counts of first-degree sexual assault on a child and two counts of risk of injury to a minor... [Assistant State's Attorney Robin] Schwartz graphically described for Judge Terence Sullivan the abuse [Defendant] inflicted on her. In addition to the sexual assault, [Defendant] showed the child pornographic magazines and pornographic torture websites."

“Pair sentenced to death." John Welsh. Press-Enterprise, September 8, 2006. "[Victim] was 16 when she was kidnapped...in late March 2001. Two weeks later, her nude body was discovered inside a horse trailer...Earlier this year, separate juries convicted a Rialto couple...of murder. They also determined the couple was eligible for the death penalty for kidnapping and torture....The defendants held [Victim] captive during a 14-day period, gave her drugs, intimidated her with firearms and sexually exploited her...The judge mentioned other girls whom the couple had been suspected of stalking and assaulting, evidence that came out during the penalty phase of the trial...[Riverside judge Paul] Zellerbach said that [male Defendant] used [female Defendant] as the lure or bait for young girls to participate in the sexual sadism that would follow. [Victim's] last moments were especially brutal. She was tied to rafters by both her hands and her feet and violated...'It was [female Defendant] who...approached [Victim] in this very vulnerable position, put the gun to her forehead and pulled the trigger,' Zellerbach said." 
“'Cannibal' death list.” Andy Geller. New York Post, April 17, 2006, http://nypost.com/2006/04/17/cannibal-death-list/. "A fiend who killed a freckle-faced Oklahoma girl...as part of a diabolical plan to eat her flesh had a long list of potential victims, authorities said yesterday. '...These other targets were both male and female, both children and adults,' said Police Chief David Tompkins...The death of [Victim], 10, 'appears to have been part of a plan to kidnap a person, rape them, torture them, cut off their head, drain the body of blood, rape the corpse, eat the corpse...,' he said...[Defendant], 26, confessed to killing the pretty girl, whose nude body was found in a plastic container in his bedroom closet...Tompkins said [Defendant]...bashed [Victim] in the head three times with a wooden cutting board, smothered her with his hands and duct tape, and sexually assaulted her corpse. There were deep saw marks on her neck 'in an apparent attempt to decapitate her,' he said. Investigators seized a hacksaw, a decorative dagger, meat tenderizer, barbecue skewers, the cutting board and a video of a TV documentary about serial killers from the apartment." [Author's note: A jury found Defendant guilty of first degree murder. The Defendant's plot was "fueled by cannibalistic fantasies and Internet pornography" (Murphy, 2003).

"Preying on the paperboy." David Krajicek. New York Daily News ("The Justice Story”), March 12, 2006. "The Sunday papers were late...The paperboy, [Victim1], 13, was a reliable kid...[Victim1] had left home before sunrise that day, Sept. $18,1983 . .$. The body turned up...in a patch of weeds...He had been stripped to his underpants, gagged with tape, bound at the wrist and ankles and stabbed to death. Investigators counted nine knife wounds and a number of bite marks. There was no indication of rape...He had been tortured with a knife and died a dreadful, slow death...Eleven weeks later, the unthinkable happened again...[Victim2], 12, disappeared while walking to school...[P]heasant hunters found the boy's body....[Victim2] had been stripped to his underwear and stabbed to death. The killer had plunged a knife seven times into the boy's torso, carved a design in his chest, bit him repeatedly, then savagely drew the knife so deeply across his throat that he nearly cut off the child's head...[H]e had been tortured... Offutt [Air Force Base] airman, [Defendant], 21...was charged with murder, and he confessed...He admitted he had sadistic homosexual fantasies from an early age. He said he was obsessed with true-crime stories that featured sexual violence...He pleaded guilty to the Nebraska murders...”

“Jury recommends death for child killer." $C N N$, December 1, 2005, http://www.cnn.com/2005/LAW/12/01/smith.sentenced/index.html. "A Florida jury voted 10-2 Thursday to recommend that [Defendant] should be put to death for the rape and murder of an 11-year-old girl...The case drew national attention after a security camera showed [Victim] being led away by a man in a blue shirt... [Defendant], a former auto mechanic and father of three daughters, was convicted...of kidnapping, first-degree murder and sexual battery... [Defendant] pleaded not guilty to all three counts, but his brother, John, tearfully testified that Smith confessed to him that he had 'rough sex' with the girl before strangling her."

"Plans to kill girl told in e-mail." Angela Rozas. Chicago Tribune, November 18, 2005, http://articles.chicagotribune.com/2005-1118/news/0511180259 1 raping-penalty-body. "For more than a year, [Defendant1] and his accomplice, [Defendant2], discussed online how they wanted to sodomize, rape and kill young girls, and schemed how they could get away with the crimes, prosecutors said...In...online chats, [Defendants] reportedly talked of raping the girls to death, chopping up their bodies, disfiguring them with chemicals and burying them. 
Some of those chats were read into evidence at the sentencing hearing for [Defendant1]..., who was convicted in April of raping and murdering 14-year-old [Victim]...[Defendant2], 24, was convicted of the same charges... Prosecutors are seeking the death penalty...Dan Ferraro, an investigator..., testified that he found 23,000 hits for the word 'rape' in [Defendant1's] computer, and downloaded 175 videos of women and girls being raped. He also said they found 1,800 suspected images of child pornography on his computer...[Victim's father] said...'All I want to know is why...Why did they look at [Victim] as a piece of nothing?”"

“Prosecution Lays out Case for Tough Sentencing of B.T.K. Killer." Jodi Wilgoren. New York Times, August 18, 2005, http://www.nytimes.com/2005/ 08/18/national/18btk.html?pagewanted=all\&_r=0. "[Victim] already watched the man strangle and suffocate her parents and younger brother when he led her to the basement he would later describe as his dungeon. There, he hanged her from a sewer pipe and yanked her white cotton panties down over her rope-bound ankles...And then [Victim], all of 11, asked what would become of her. 'I said, "Well, honey, you're going to be in heaven tonight with the rest of your family," Dennis L. Rader told investigators after his arrest, recounting how he let the girl's toes dangle a fraction of an inch from the floor to slow her death, then masturbated... Such horrifying details... emerged...in the opening day of an unusually lengthy sentencing hearing for Mr. Rader, who terrorized this central Kansas City for three decades as 'B.T.K.,' a name he chose for his methods - bind, torture, kill...Acknowledging that the two-day hearing might sexually satisfy...Mr. Rader, District Attorney Nola Fouston...said outside court, 'Sometimes you have to feed the dragon before you can put its fire out.' A macabre cache of memorabilia ...kept in a file drawer in [Rader's] office, held the stuff of a horror movie... line drawings of his fantasy of turning a barn into a torture chamber and naked women in bondage positions...clippings about the killings; and essays describing them in minute detail...Interrogated after his February arrest, Mr. Rader bragged about tying a woman's hands behind her back, because in the bondage world that's really high stuff,'..."

"To catch a monster, using anti-terror law." Mark Mueller. Star-Ledger, August 14, 2005, http://www.nj.com/news/ledger/index.ssf?/news/ledger/stories/patriotact/partfour.html. “...The arrival of Tom Clinton and Denise Holtz at the home of a missing child can be viewed as a hopeful sign or a bad omen. Hopeful because the two are widely considered dedicated investigators...It's what they investigate that gives rise to a parent's greatest fear...[Victim] came into their lives...when a supervisor popped his head into their windowless fourth-floor office at FBI headquarters on Pittsburgh's South Side. He told them to look into a report of a missing girl. Holtz and Clinton called Pittsburgh police for a briefing, asking specifically if [Victim] spent a lot of time on the Internet...She had...Holtz and Clinton knew that children will share with friends information they never would tell a parent...One friend said [Victim] confided she had recently met...a man, in an online chat room. The girl didn't know a name, but she said [Victim] had been communicating with him through instant messaging deep into the night... Holtz and Clinton didn't have a name...They got one later that night... The call had been made to the [FBI] Tampa office...[The caller had] been instant messaging with...someone named Scott from Virginia, with whom the caller had become acquainted through bondage and discipline clubs on Yahoo.com. Scott had been talking for some time about finding a teenage girl to make his slave...[O]n New Year's Day, Scott had told him, 'I think I got one,' mentioning a planned trip to 
Pittsburgh...Scott wrote again. 'I got one,'...To prove it, Scott posted a Webcam image of a young girl...On Yahoo, he went by the screen name 'masterforteenslavegirls.' With the screen name in hand, investigators found Scott's Yahoo profile. It contained no last name, but it did have photos...Another showed the same man posing before a wall of implements associated with sexual torture...There was more...Scott had sent another image. This time the girl's arms were bound, suspended above her head from the ceiling. She had been beaten. And she was crying... In Virginia, the agents had smashed through [Scott's] front door...They found [Victim] cowering in a corner of an upstairs bedroom. A chain extended from a collar around her neck to an eyebolt in the floor." [Author's note: Scott pleaded guilty to two federal counts, sexual exploitation of a minor and travel with intent to engage in sexual activity with a minor.]

\section{"In Syracuse, a Kidnapper's Plea Unravels Four Unsolved Crimes."} Michelle York. New York Times, June 14, 2005, http://www.nytimes.com/2005/06/14/nyregion/14syracuse.html. "A kidnapper who... snatch[ed] girls from the streets to sexually assault them and leave them bound with tape, might still be at large if not for the odd markings on his arms and his own guilty conscience...According to his confession, on April 24, 2004, [Defendant]...saw a 5-year-old riding a Barbie scooter. He kidnapped the child, assaulted her and left her for dead in a desolate warehouse...The next day, a man...heard the girl's soft cries and found her under a tarp, bound tightly with duct tape. She was able to describe the man who had snatched her, investigators said. This April, [Defendant] was questioned in the molestation of the 4-year-old daughter of a family friend. Sheriff's Detective William Root of Onondaga County took note of the striking markings on his arms...He said he knew that a tattooed man had been described in the unsolved kidnapping of a 16-year-old...Later, [Defendant] confessed to four separate crimes - including three kidnapping...and took investigators on a tour of the abduction sites. [Defendant] told investigators that he snatched his first victim, a 16-year-old girl, on March 22, 2003, as she walked with her friends... On Sept. 1, 2003, [Defendant] snatched a 14-year-old girl from a park and sexually assaulted her, leaving her bound to a tree, investigators said..."

“Killing Michael Ross." Zack Jones. Yale Daily News, January 24, 2005, http://yaledailynews.com/magazine/2005/01/24/killing-michael-ross/."Michael Ross, the former insurance salesman who killed eight Connecticut women in the 1980 s, has pulled the plug on an appeals process that had dragged on for nearly 20 years. He is 'ready to die,' he says...In 1983, Connecticut State detectives began tracking a serial killer after the raped and strangled bodies of young women, ages 14 to 23 , turned up in the eastern part of the state...Years later, he would also plead guilty and received life sentences in New York State for murdering two women while he was a student at Cornell...To many, Ross epitomizes the kind of coldblooded killer for whom capital punishment was intended. His crimes were heinous. He raped seven of his eight victims, and only spared the eighth because he had just raped her best friend before he killed them both. He was calculating: in every instance, he would ask the each girl to lie on her stomach so he could tie her up - only to strangle her instead...At the penalty phase of the trial...the public defenders sought to prove that he suffered from sexual sadism, a rare deviance that they said significantly impaired his ability to control his actions...[P]rosecutors argued, even if he was a sexual sadist, that didn't diminish his legal and moral culpability. 'No way does the fact that a man is a sexual sadist say it's all right for him to go out and pick up little girls, rape them and kill them,' Satti stated in his closing 
arguments. The jury agreed with him, and sentenced Michael Ross to death.” [Author's note: Ross was executed.]

"Mom's sleuthing helped find missing daughter." Margaret Ellis. Columbian, September 14, 2004. Fourteen-year-old [Victim] is home; and the man who is alleged to have held her captive and tortured her for the past two weeks is in jail...[Defendant] was charged...with three counts of third-degree rape of a child, two counts of sexual exploitation of a minor and one count of first-degree kidnapping...[Victim] walked away from...home...to meet [Defendant]...According to court documents, [Defendant] kept her chained to a bed while he was at work. Police say he beat her and took sexually explicit pictures of her. He also allegedly forced her to engage in sex acts with a woman...Last week, frustrated by what she saw as inaction.... [Mother] began... researching the Web sites her daughter frequented and contacting people her daughter chatted with online...[S]heriff's deputies found [Victim] in [Defendant's] home. According to court records, she was curled into the fetal position on a bed. She wearing only a plaid skirt, and was surrounded by chains and sexual devices...Officers found a room...containing a bench with chains and restraints, a video camera on a tripod, sexual devices, lingerie and pornography...”

“No porn allowed in trial." Sheila Toomey. Anchorage Daily News, July 28, 2004. "In a decision issued after the close of testimony Tuesday, the judge in [Defendant's] murder trial banned any mention of [Defendant's] Internet pornography collection to the jury. Superior Court Judge Stephanie Joannides said experts strongly disagree about whether there is a connection between pornography and sexual crimes. Prosecutor Adrienne Bachman had argued for weeks that describing [Defendant's] immersion in hard-core porn was necessary to help jurors understand how a 16-year-old boy with no criminal record could conceive the terrible things done to the [13-year-old female Victim]...Her body was found in the woods near her home. She had been repeatedly stabbed and slashed and, Bachman said, obscenely posed to resemble pornographic pictures. But Joannides said there is no 'nexus,' no demonstrable, relevant connection between [Defendant's] interest in porn and what happened to [Victim]." [Author's note: A jury subsequently convicted Defendant of first degree murder.]

"Baby Sitter, 17, Raped and Tortured Three Children for a Year, Police Say." Avi Salzman. New York Times, February 27, 2004, http://www.nytimes.com/2004/02/27/nyregion/baby-sitter-17-raped-and-tortured-three-children-for-a-year-police-say.html. "A teenage baby sitter...has been charged with raping and sodomizing three children [boys age 7 and 13 and an 8-year-old girl] he was watching in their home over a period of more than a year...[Defendant], a 17year-old..., was charged with three counts of sexual abuse and three counts of risk of injury to a minor. By state law, he will be tried as an adult...The youth had been abusing the children since the summer of 2002, when he began watching pornographic videos with the eldest child..., the warrant said. He eventually abused all three children, the state police charged. He intimidated the children by telling them he would assault other members of the family if they did not comply with his requests, and he tortured them with a knife, among other items, the warrant said." [Author's note: Defendant was convicted and sentenced to 20 years in prison.]

Benefiel v. Davis, 357 F.3d 655 (7th Cir. 2004), http://law.justia.com/cases/federal/appellate-courts/F3/357/655/615448/. "In 1988, Bill J. Benefiel was sentenced to death for murdering Delores Wells in Terre Haute, 
Indiana, in 1987. His conviction...and his death sentence have been upheld by the Indiana Supreme Court... He is now before us...We start with the facts, which curl the stomach and numb the mind. The story of this gruesome crime begins with another victim, [Victim1]. On October 10, 1986..., [Victim1], who was then 17 years old, walked to a gas station two blocks from her home...Her family did not hear from her again for 4 months. During those months, Benefiel, who had abducted [Victim1] off the street, tortured and raped her repeatedly...At various times he stuffed clothing or toilet paper in her mouth and put duct tape over her eyes and mouth. For the first 2 months her eyes were glued shut. He fastened her to a bed, naked, with a chain around her neck. At times he handcuffed her to the side railing of the bed and tied her feet together with a rope. When she screamed he slapped her and cut her with a knife. He cut off one of her fingernails... At one point he stuck a gun in her vagina and forced her to have anal intercourse. She was convinced escape was impossible because of his dogs...About a month later, in January 1987, [Victim1] heard noises which indicated to her that someone else was in the house...[Victim1] first saw [Victim2] lying naked and handcuffed on a bed. She had tape over her eyes and paper towels stuffed in her mouth, which was then taped over. On February 4, while [Victim1] watched, Benefiel began beating [Victim2], first with his fist and then with an electrical cord. Another time, he...cut off her finger. He also told her she would die slowly...Benefiel also made [Victim1] watch as he put super glue in [Victim2] nose and pinched it together. He then put toilet paper in her mouth and taped it shut. Wells began squirming, trying to breathe. A little later Benefiel chained [Victim1] to her bed and left the house. When he returned about 2 hours later ...he told [Victim1] that he had killed [Victim2] by tying her arms and legs to two separate trees. He then wrapped duct tape around her head until she died...A jury trial...resulted in a bevy of convictions. The jury recommended the death penalty and the trial judge imposed it...For all these reasons, the judgment of the district court...is AFFIRMED.”

"Newport man guilty of 2001 rape, torture." Claire Luna. Los Angeles Times, July 11, 2003, http://articles.latimes.com/2003/jul/11/local/me-dance11. "A 22-year-old former UC Irvine student could be sentenced to multiple life terms after being convicted...of torturing and raping a 15-year-old...girl he met through the Internet...[Defendant] is scheduled to be sentenced...for seven felonies: three rape charges, forced oral copulation, robbery, criminal threats and torture. The girl...testified that [Defendant] picked her up... and then drove her to a UCI parking lot deserted over the winter break. He held a knife to her throat and threatened to kill her, then covered her eyes and bound her wrists with duct tape. Then he raped her, whipped her with his belt hard enough to fracture a front tooth and tried to carve swastikas in her face. According to computer experts, the day before the attack [Defendant] browsed pornography Websites he found after searching the Internet under the words 'brutal rape."

“N.Y. Police Seek More Sex Dungeon Victims.” ABC News, April 30, 2003, http://abcnews.go.com/GMA/story?id=125201\&page=1\&singlePage=true. "The 67-year-old retired handyman accused of kidnapping at least five females and keeping them as sex slaves in an underground concrete dungeon may have been active since the 1980s, police say. [Defendant] is accused of luring or pulling his victims into his car, and then bringing them back to his house, where he allegedly kept them chained in a two-room bunker beneath his back yard...[Defendant] is being held without bail on charges of kidnapping, rape, sodomy and sexual abuse of a 16-year-old girl, whom he allegedly held hostage from October or November 
until earlier this month... The latest victim to come forward...was 53 when [Defendant] allegedly snatched her off the street...She said he choked her twice, and then drove her to the house, where he raped her twice and chained her up...Officials say [Defendant] chose his victims with no real pattern. Police say the victims include a 14-year-old girl taken in 1988, a 13-year-old girl in 1995, a 53-year-old woman in 1997, a 26-year-old in 2001, and the 16-year-old freed earlier this month..." [Author's note: Defendant pleaded guilty to five counts of first degree kidnapping.]

"Long Island Man Found Guilty of 63 Counts in Sex Torture of Teenager." Bruce Lambert. New York Times, December 7, 2002, http://www.nytimes.com/2002/12/07/nyregion/long-island-man-found-guilty-of-63-countsin-sex-torture-of-teenager.html. "A jury today convicted a Long Island man of luring a 15-year-old...girl from an Internet chat room devoted to sadomasochism into a real-life, weeklong ordeal of torture and sexual abuse...[A] jury found the man...guilty of 63 assorted charges of kidnapping, rape, sodomy, sexual abuse, assault and endangering the welfare of a child...Mr. Kelly, the defense lawyer, had argued that the victim had repeatedly lied about her age...The defense also argued that the girl had given her consent... Throughout the ordeal, the girl was subjected to various sexual activities with all three adults. She was also hit, whipped, tied up, hanged, choked with belts and rope, smothered with a plastic bag over her head, stuck with needles and tortured with a cigarette lighter..."

"Notes link suspect to Lisk case: Tie to 2 other slayings examined." Kiran Krishnamurthy. Richmond Times-Dispatch, June 30, 2002. "Evonitz, 38, had been wanted for questioning in the Spotsylvania County [VA] slayings of the Lisk sisters and Sofia Silva when he shot himself... Florida police were trying to arrest him in connection with the abduction and rape of a South Carolina teenager...Former neighbors said Evonitz lived in Spotsylvania at the time Sofia Silva, 16, was abducted and killed....and when Kristin and Kati Lisk, 15 and 12, respectively, were abducted and killed...Along with the handwritten notes found in Evonitz's Columbia [SC] apartment, investigators found...sex toys, pornographic movies and bondage devices, according to law enforcement sources...Authorities have not said how the Lisk girls and Silva died, although sources have confirmed the two sisters were asphyxiated... Authorities in South Carolina and Florida provided this description...On Monday, Evonitz approached the South Carolina girl...He took her to his apartment...where he repeatedly raped her and made her watch pornographic videos. She was bound in handcuffs on her hands and ankles...[S]he wriggled free while he was sleeping...and ran from the apartment, where two men helped her get to safety..." [Author's note: The FBI issued a Violent Criminal Apprehension Program Alert on March 14, 2008 "seeking assistance with identifying additional abductions, sexual assaults, and/or homicides that may have been committed by Richard Marc Evonitz throughout the United States.” The Alert said Evonitz had a preoccupation with...binding of victim hands and/or feet; use of sex toys and/or pornography (both adult and child)...”]

“Sex-slay teen's final nightmare." Kieran Crowely. New York Post, December 5, 2001, http://nypost.com/2001/12/05/sex-slay-teens-final-nightmare/. "The terrified teen victim of a sadistic ex-teacher dubbed New York's own 'Hannibal Lecter' begged for mercy before being castrated, but his attacker coolly retorted, 'I can't stop now - don't you see that?' The chilling exchange was one of several horrifying details that surfaced yesterday...as prosecutors went to court to fight cannibal killer [Defendant's] possible release from a Long Island psychiatric hospital. 
[Defendant], 59, has been locked up in mental hospitals for the past 22 years for the sex-mutilation slaying of 18-year-old [Victim] in Poughkeepsie in 1979. Prosecutors tried to remind the Suffolk County jury of the horror [Victim] experienced that August night, when he was lured to the basement of the then-eighth-grade social-studies teacher and tied up. As [Defendant] sexually assaulted [Victim] and began cutting off his penis and testicles with a straight razor, the boy writhed in pain...said Dutchess County prosecutor Edward McLaughlin...[Victim] begged, "You don't have to do this." But his sicko attacker was unmoved... [Defendant] then shot [Victim]..., went upstairs, sautéed the boy's genitals in oil and ate some."

"Rapists bet on victims' silence - and lose." Alex Tizon. Seattle Times, May 31, 2001, http://community.seattletimes.nwsource.com/achive/?date=20010531 \&slug=mukogawa31m. “...[T]hree Japanese teenagers waiting at a bus stop accepted a ride from a smiling American woman...The driver picked up two men waiting nearby. The students were handcuffed and blindfolded. One woman was...released; the other two were brought to a...house where they were raped over seven hours. The assaults were videotaped and photographed. The students were informed that if they told anybody..., the videotapes would be sent to their fathers. The [other two] women eventually were dropped off a short distance from the bus stop...A week later, three locals were charged with multiple counts of kidnapping, rape and witness intimidation...The leader...was.... devotee of bondage and sadomasochism. He co-founded...a sex club of about 200 members, which met regularly for sex parties and bondage workshops." [Author's note: All three defendants pled guilty to various crimes. According to an article in the Washington and Lee Journal of Civil Rights and Social Justice (Woan, 2008) the leader "professed an avid fascination in bondage, sadomasochism, and Japanese culture. He collected Japanese bondage videos and was an expert in Japanese rope-tying techniques.”]

“Guilty Plea Saves Life of Rapist-killer of 9-year-old.” Dave Racher. Philadelphia Daily News, March 15, 2001, http://articles.philly.com/2001-0315/news/25328317_1_gilson-guilty-plea-first-degree-murder. "The 9-year-old girl was living with a monster, the prosecutor said. And last May..., [Defendant], 43, acted like one by raping and murdering [Victim] inside his...home, said Assistant District Attorney Mark Gilson. [Defendant], a criminal-justice major at Penn State University, who kept 6,000 pornographic pictures on his home computer, acted out his fantasies by binding [Victim] with duct tape before beating, raping and strangling her with a telephone cord, said Gilson...[Defendant's] lawyer...talked him into pleading guilty to first-degree murder and sexual assault to save his life. Gilson agreed to drop a rape charge to get the plea...Gilson said the images on [Defendant's] computer depicted children, women and men in acts of bondage, simulated strangulation, hanging and sadomasochism. [Victim's] mother had fallen on hard times, and moved in with [Defendant] about two months before the murder."

United States $\boldsymbol{v}$. Richardson, 238 F.3d 837 (7th Cir. 2001), http://openjurist.org/238/f3d/837/united-states-of-america-v-thomas-c-richardson. "The defendant pleaded guilty to receiving and possessing child pornography (including visual depictions) in violation of 18 U.S.C...2252(a)(2) and (a)(4)(B) and was sentenced to 108 months in prison. He had downloaded more than 70,000 pornographic images from Internet-accessed newsgroups...The FBI examined a random sample of 1,300 of these images and discovered that 77 depicted bondage and torture of children. The sentencing judge raised Richardson's base offense level by four levels under U.S.S.G. sec. 2G2.2(b)(3) because the bondage and torture 
pictures "portray[ed] sadistic or masochistic conduct or other depictions of violence'...The appeal challenges the two punishment enhancements...Affirmed."

“Cops Seek Other Child Victims in Cannibal Case....” Douglas Belkin. Boston Globe, December 31, 2000, http://www.sfgate.com/news/article/Cops-SeekOther-Child-Victims-in-Cannibal-Case-2718264.php. “...The mark, prosecutors say, was where Bar-Jonah screwed a pulley into the ceiling, attached a nylon rope and hanged young boys by the neck to fulfill his sexual fantasies...Bar-Jonah, 43, is a Massachusetts native who, according to a Montana prosecutor, was dumped here by Massachusetts authorities after he had molested at least three children...Bar-Jonah served 12 years at the Massachusetts Treatment Center for the Sexually Dangerous in Bridgewater, then in 1991 a judge allowed him to leave the state to go to Montana and live with his mother. Now he has been accused of kidnapping, molesting, butchering, and eating the remains of at least one young boy...Bar-Jonah has been in the county jail since he was picked up a year ago for impersonating a police officer in front of an elementary school while allegedly stalking a 5-year-old...When police finally went into Bar-Jonah's corner apartment..., they discovered tens of thousands of photographs of children from the area....Mixed in with the clippings were thousands of photos of naked and half-naked children, many of which Bar-Jonah is alleged to have taken, along with photos of his genitals. Police also found encrypted menus referring to cannibalizing children...Taken with various psychological evaluations...describing Bar-Jonah's fantasy life as filled with a fascination with torture, dissection and eating human flesh, authorities aren't sure how many other victims they may yet find...Most unnerving of all is that Bar-Jonah was typically surrounded by children, neighbors say...Not everyone was so vigilant. Another mother allowed her children to play with BarJonah...Her three sons were all molested, authorities say, and at least one of them was hung from the pulley, and another was handcuffed to a pole at various times in 1998." [Author's note: Bar-Jonah was convicted of kidnapping, aggravated assault, and sexual assault. He died in prison.]

"Doctor charged in sex case...." Ben Goad. Press-Enterprise (Archive), December 6, 2000. "A...pediatrician...was charged...with using the Internet to recruit a 12-year-old girl to be his sex slave, county prosecutors said. In all, 11 felony counts were filed against [Defendant], said San Bernardino County Deputy District Attorney David Hidalgo...[Defendant] stands accused of using the Internet to search for a young girl to hit with a riding crop and flogger - someone to be a victim to various criminal disciplinary and sadomasochistic acts...[Defendant] was arrested...by undercover detectives who posed on the Internet as a mother who agreed to allow [Defendant] to molest her 12-year-old girl...Detectives said they set up the sting operation after learning that the Kaiser doctor...was seeking such a girl to tie up with chains and molest. 'He told them (detectives) exactly what he was going to do,' Hidalgo said. 'He told them about rituals he was going to perform to train her as his sex slave.'...[Defendant] also is alleged to have...sent the supposed girl pornographic images via the Internet. Included among those photographs are photos of women in sexual bondage, said Hidalgo. One image showed a young girl locked in a cage, he said. [Author's note: Defendant pled guilty to various charges.]

"Moms keep vigil for slain girls: Endure explicit testimony during suspect's trial." Laura Italiano. New York Post, November 28, 2000, http://nypost.com/2000/11/28/moms-keep-vigil-for-slain-girls-endure-explicit-testimony -during-suspects-trial/. "One girl may have been burned alive on a rooftop. Another had her life's breath squeezed out of her, and a third, only 13, was strangled 
and stabbed three times. No mother should have to suffer what the mothers of these three murdered teenage girls are suffering...For a month now, they have...attended the...trial of 29-year-old [Defendant], accused of attacks on seven teenage girls: their three murdered daughters and four others who survived being raped and sodomized...The crime scene photos...show three...girls whose bodies were punctured, bruised or charred...The mothers have also had to listen as each of the four surviving girls described being dragged at knifepoint or gunpoint into the dark, litter-strewn stairwells of her apartment building - there surviving the same depravity that their daughters may also have endured before dying. 'This man is pure evil,' one police investigator says of [Defendant]..." [Author's note: In another article, the New York Daily News (Peterson, 2000) (reported that defendant made his victims "strip naked and blindfold[ed] them during the attacks."]

"Scoutmaster charged with holding boys in bondage." Ernie Hoffman. Pittsburg Post-Gazette, June 14, 2000, http://old.post-gazette.com/neigh_westmoreland/20000614scout3.asp. "An assistant scoutmaster was charged with placing three young boys [ages 11, 12 \& 13] in bondage and cutting large ' $T$ ' on their chests with a folding knife while they were tied to trees during an overnight camping trip...Police said a search of the home produced a knife matching a description given by the boys, rope, elastic bandages, a paddle and pornography dealing with bondage and other sexual deviations...Police said [Defendant], 52, confessed to the assaults and told them he did it because he was fascinated by bondage and that it made him sexually aroused...[Defendant] faces three counts each of child endangerment, corruption of minors, unlawful restraint, reckless endangerment, simple assault and harassment." [Author's note: Defendant pleaded guilty to various charges.]

Affidavit of Probable Cause to Obtain Bail, Detective Sergeant Terry Woodside Arkansas $v$. Carpenter \& Brown, Circuit Court of Benton County, Arkansas, September 27, 1999. “...While being questioned..., [Defendant2] stated that he was [Defendant1's] lover...[Defendant2] stated that on this occasion he snuck up on [Victim], tied his hands behind his back, placed a pair of underwear in [his] mouth and secured them with a bandana and duct tape. He placed a bandana over [his] eyes and secured it in place with duct tape. He then placed a tee shirt over [his] head, and checked to ensure that [his] nostrils were not covered. He placed belts around [his] knees and ankles to hold his legs together. [Defendant2] then untied [Victim's] wrists and secured them to opposite sides of the mattress. He positioned [Victim] on his stomach, placing pillows under his stomach. [Defendant2] then proceeded to penetrate [Victim's] anus with various items, including three (3) fingers of his hand, his penis, a cucumber, a sausage, a banana and a douche bottle... [Defendant2] stated at one point he prepared and administered an enema for the victim, using his own urine...[Defendant2] then positioned a cucumber so that it was slightly penetrating [Victim's] anus, and secured it with tape. He then went to the kitchen, where he ate a sandwich before returning to the bedroom. Upon his return, he found that [Victim] was apparently not breathing...[Defendant2] also guessed [Victim] to be 13 or 14 years old...During the search of [Defendant1's] residence, Detectives recovered...numerous items used in bondage..." [Author's note: Defendant1 pleaded guilty to rape/murder. Defendant2 was found guilty of rape/murder. There was evidence that the boy had been sexually involved with one or both defendants.]

“Shocking 'Confession' of HS Sex Suspect.” Murray Weiss. New York Post, October 28, 1999, http://nypost.com/1999/10/28/shocking-confession-of-hs- 
sex-suspect/. "One of three teens charged yesterday in the vicious assault and sodomy of a 16-year-old girl at a Queens high school 'wanted to know what it was like to be a rapist,' investigators said. The 18-year-old suspects...were charged with sodomy, kidnapping, sexual abuse and assault..., Queens District Attorney Richard Brown announced...The three are all 10th-graders at the school. 'She was punched in the face. Her hands were bound,' Brown said of the victim, also a 10th- grader. 'She was strangled with a belt and left unconscious...[A]ccording to an investigator, one of the suspects took off his belt and choked the girl, causing her to drift in and out of consciousness." [Defendants1\&2] committed sodomy and [Defendant3] acted as lookout, the investigator said.

“Sexual Stalkers May Not Go Free....” Ludmilla Lelis. Orlando Sentinel, February 12, 1999, http://articles.orlandosentinel.com/1999-02-12/news/990212 0234_1_offender-treatment-ryce-sexual-crime. "Convicted sex offender [Defendant] was set to be released from prison last month but could be confined for the rest of his life under a new law targeting violent sexual predators. The 25-yearold...is among 30 current Florida prisoners who could be held indefinitely under the Jimmy Ryce Act...Psychologists say [Defendant] has the type of mental disorder that classifies him as a sexually violent predator. In 1995, he pleaded guilty to lewd and lascivious assault on a child for sexually torturing his 15-year-old girlfriend and was sentenced to nine years in jail. But he is now eligible for release after serving half his term. During the assault, which he videotaped, [Defendant] used knives, whips and chains on his victim and gave her various drugs, including LSD, according to court records. A psychological evaluation in December determined that he suffers from sexual sadism..."

"Teacher Is Arrested in Internet Child Pornography Case." Robert Hanley. New York Times, April 1, 1997, http://www.nytimes.com/1997/04/01/nyregion/teacher-is-arrested-in-internet-child-pornography-case.html. "A 31-year-old kindergarten teacher in Brooklyn was arrested on child pornography and sexual assault charges after going to a New Jersey motel...for what he thought would be a sexual rendezvous with an 11-year-old boy, Federal officials said yesterday. Instead, the teacher...encountered an undercover detective...The U.S. Attorney in New Jersey...has charged him with illegal interstate transmission, via computer, of photographic images of naked young boys engaged in sexual acts, some while in bondage... When Defendant arrived [at the motel], he was carrying two gym bags. Items in the bag included a stuffed dog, dog leashes and leather restraints, Ms. Krappa, the assistant United States attorney said.”

"Taped Beating." Associated Press. May 20, 1996. "The founder of a youth tutoring program who allegedly videotaped himself torturing teen-age boys surrendered to federal authorities.... [Defendant] was charged with one count of possessing three or more videotapes showing a minor engaging in sexually explicit conduct...The 50-minute videotape viewed by the Associated Press and other media shows [Defendant] whipping three [black] teen-age boys on their backs, torsos and buttocks. He is also seen pushing a sharp object under their fingernails and rubbing oil on their bodies. At times the teens are naked and tied with ropes. At one point in the recording, [Defendant], who is white, appears to be assume the role of a South African who is punishing a black teenager. 'There is not a part of your body we will not torture,' he says on the tape...[Defendant] admitted to videotaping the sessions, U.S. Attorney...Droney said.” 
"Sickos 'relive' crimes on video; Porn influences killers: Doc." Toronto Sun, October 29, 1995. "Sexual sadists like Stanley Pomfret...often create videotapes or written 'stashes' of their attacks as mementoes, experts say. The words and images help feed their obsession until the next victim comes along, says Dr. Patrick Carnes...This week in a closed...courtroom, video and audio tapes of horrific assaults on two young girls were played...The two girls, ages 14 and 15, said they were raped orally, vaginally and anally five times over a 12-hour period. They were also tortured with clothespins clipped on their nipples and one girl's vagina area...Dr. Stanley Yaren...said recording the acts is also a way to further humiliate the victim...Carnes said the destructive behavior in many cases can be linked to pornography...Pomfret kept a scrapbook of sadistic rape and torture scenes clipped from magazines. He also compiled video clips from hardcore porn films that showed women being whipped, beaten and sliced with razors."

"British Serial Killer Sentenced to Life Term for Grisly Slayings." Associated Press. Los Angeles Times, September 23, 1995, http://articles.latimes.com/1995-11-23/news/mn-6430_1_rosemary-west. One of Britain's worst serial murderers went to prison for life...protesting she was innocent of torturing and killing 10 women and girls, including a daughter and a stepdaughter...Throughout the seven-week trial [Rosemary] West blamed all the killings on her husband, Frederick West. He had been charged in the case but killed himself before being tried... The prosecution said the Wests lured the young women, many of them vulnerable runaways, with offers of rides, lodging or jobs as nannies. They were stripped, bound with adhesive tape and sexually tortured, then killed, dismembered and buried. Many were gagged to prevent them crying out. All but one of the victims were found buried at the West home..." [Author's note: In a later article, Woodrow (2011, July 3) writes:

How sad then that Fred...was a paedophile. He wasn't good at sex....and preferred the role of voyeur. He wanted to observe his young girlfriend with other men and introduce Rose to his other penchant: sadomasochism. Fred wanted to be tied up and beaten and purposefully left S\&M pornography lying around for his young mistress to see. The couple began to develop sex games involving bondage and sadomasochism, which would later become their modus operandi inflicted on their victims...Had she not met Fred it is highly unlikely that Rose would have become a serial killer but as Detective Superintendent John Bennett, who led the investigation, said recently: "The whole case was about Rosemary being sexually insatiable. There were huge quantities of pornographic material and sex objects in the house... ]

\footnotetext{
“Sex shame on ex-prison chief." Steve Smith. PA News (UK), July 25, 1995. "A former prison chief admitted sexually abusing 12 teenage boys and taking pornographic pictures of them at his home. [Defendant]...pleaded guilty to 12 charges of shameless indecency, and lewd and libidinous behavior...The High Court in Aberdeen heard that 61-year-old [Defendant] lured boys to his house offering to teach them self-defense...[Defendant] removed the boys clothing, masturbated them and took photographs of them in pornographic poses. On various occasions, he also sexually abused a 17-year-old boy after binding his hands and legs and gagging him.”

“Killer's letter: Porn film inspired murder." Emily Hornaday. Times of Trenton, May 10, 1995. “...[Defendant] wrote about the incident in a 12-page
} 
letter to a psychiatrist who was treating him in 1998...Yesterday [Defendant's] attorneys tried unsuccessfully to block a portion of that letter from being read during a hearing on his request to be moved to a private psychiatric facility. [Defendant], $42, \ldots$ was found not guilty by reason of insanity in the...killing of 18 -year-old [Victim]... [Defendant] was stopped by police when he left [Victim's] home, and he told officers...he had just electrocuted a woman. At police headquarters, [Defendant] said he had put a T-shirt that had eye holes cut out over his head at the time of the assault. In the 1988 letter, [Defendant] describes...stopping at an adult bookstore two days before the killing. He said he went into several [peep show] booths and masturbated. He then fixated on one graphic film in which a man in a black hood was electrocuting a woman tied to a post. [Defendant] had tied [Victim] to her bed...[Defendant] wrote, "In no other crime did I attempt to cover my face."”

"Man gets 3 years in sex-via-computer case...." Sandra Gonzalex. San Jose Mercury News (Archive), July 9, 1994. “...[A] remorseful...man was sentenced to more than three years in prison...for his sadomasochistic encounter with a [14year-old] boy he met through an on-line service... [Superior Court judge] Gordon said he did not give [Defendant] the maximum term because he took into consideration the Apple Computer engineer's lack of criminal history and early no-contest plea to two counts of lewd and lascivious conduct with a minor and one count of sodomy...[Defendant]...met the boy...after the teen-ager began using America Online, which cooperated in the investigation...[Defendant] picked up the boy....and drove him to the alley of a store parking lot where he handcuffed and blindfolded the boy. When the pair arrived at [Defendant's] home, they began an encounter that included belts and leg restraints and various sadomasochistic sexual activities...Police found whips, chains, pornographic videotapes and magazines as well as leg shackles and restraints at [Defendant's] home."

“Attempted Kidnapping by Coach Stuns Pupils." Douglas Martin. New York Times, April 27, 1993, http://www.nytimes.com/1993/04/27/nyregion/attempted-kidnapping-by-coach-stuns-pupils.html. "Mr. Wilenksy's secret world of smutty videos and a remote mountain cabin filled with torture devices seemed far removed from the 'Grampa Gary' known to the young women he taught at...the elite Manhattan girls school....and to those he coached outside of the school... According to the police,.. Mr. Wilensky attacked [Victim], who is 17, and her mother...outside a hotel...where the young woman was playing in a tennis tournament...Though Mr. Wilensky struck them repeatedly with the cattle prod, the two women fought back and escaped. A little over two hours later...the tennis pro killed himself with a shotgun blast...Mr. Wilensky seems to have become obsessed with [Victim], a student at [name omitted] High School...Early last month, the police said, Mr. Wilensky rented a remote house...two hours north of Albany, and outfitted it with such things as a stun gun, instruments of bondage - whips, chains and handcuffs - night vision glasses and motion detectors so he could monitor a prisoner in the house, as well as intruders. Most ominously, the police said, they found a pornographic video showing women in bondage and titled 'Jennifer's Nightmares.'...In attempting to kidnap the women, he brutally assaulted them; the mother received about 70 stitches and the daughter 35.”

“Supreme Court Rejects Appeal in '78 Slaying." Mack Reed. Los Angeles Times, June 11, 1991, http://articles.latimes.com/1991-06-11/local/me-639_1_supreme-court. "The U.S. Supreme Court refused Monday to hear an appeal for Theodore Frank, who was sentenced to death for the 1978 kidnaping, rape, torture and murder of a 21/2-year-old Camarillo girl. By rejecting Frank's appeal, the nation's 
highest court upheld a November decision by the California Supreme Court, which ruled unanimously that Frank should be executed for torturing and murdering Amy Sue Seitz...Evidence during his trial indicated that Amy Sue had been kidnaped from her baby-sitter's residence, bound hand and foot, forced to drink beer and then raped, tortured and mutilated with locking pliers before she was strangled. Frank killed the child just six weeks after he had been released from Atascadero State Hospital. He had a 20-year history of child molestation. In a diary presented to jurors in the first trial, Frank wrote: 'I want to give pain to these little children. I want to molest them. I want to be sadistic. I want to harm them."

“'Serial' Suspect: Arrested Man May Be Linked to Body Found Locally.” Gay Elwell. Morning Call, March 29, 1991, http://articles.mcall.com/1991-0329/news/2778534_1_murder-charges-delaware-river-arrested. "The suspect in the murder of a 15-year-old...in 1984 has been charged by the FBI with kidnapping his wife, whose body was found last year...According to...affidavits filed in connection with the arrest, [Defendant] matches the profile developed for the FBI...for the 'sexually sadistic serial killer.' Investigators say he is a suspect in the 1984 murder of former girlfriend [Victim], 15...[Defendant] returned to New York City in January 1984 and started dating [Victim] a month later...On May 3, 1984, [Victim's] mother filed criminal charges of false imprisonment and sexual assault against [Defendant], based on bruises she saw on her daughter's body, and on information in the girl's diary, which said [Victim] had been handcuffed, tortured and beaten with a belt, the affidavits say....On May 15..., [Victim's] mother filed a missing persons report...A tourist found [Victim's] body...on June 2...Her throat was slit by about five stabbing-type wounds, there was a massive hole between her eyes, she had been poked in the breast and chest with what appeared to be a pencil, and she had an apparent cigarette burn on her arm, officials said. Her feet were tied together, and the nearly total lack of blood in her body suggested she might have been suspended upside down at the time she was killed, according to affidavits." [Author's note: The New York Post (Hoffman, 1991, March 30) reported that Defendant "collected porn." Defendant was convicted of murdering his wife. He pled guilty to murdering the 15-year old.]

Spencer v. Commonwealth, $393 \quad$ S.E.2d $609 \quad$ (Va. 1990), https://www.courtlistener.com/opinion/1242445/spencer-v-com/. "In this appeal, we review a capital murder conviction and a death penalty imposed upon Timothy Wilson Spencer. Recently, we have affirmed three other such convictions and sentences...which involve...strikingly similar crimes...In the present case, Spencer was indicted for rape, breaking and entering with intent to commit rape, and capital murder...We will review the evidence...Diane Cho was a fifteen-yearold girl of Korean descent who lived with her parents...On...November 21, 1987, Diane retired to her bedroom...They found Diane's body face down on the bed...Her hands had been bound securely behind her back with a length of rope. Another rope was tied tightly around her neck with a slip knot. The end of that rope came over her back and was tied to her hands. Her body was nude, and her mouth was covered with duct tape...She was dead as the result of ligature strangulation.'...The victim's body showed acute vaginal and anal injuries and two bruises... Seminal fluid was found in the victim's vagina, and an unusually large amount of seminal fluid was found in three separate stains on a sheet...One of the matters considered by the court...was the Commonwealth's motion for permission to introduce, at the guilt phase of the trial, evidence of Spencer's involvement in the three other rape-murders described in Spencer I, II, and III...At trial, the 
Commonwealth introduced evidence...showing Spencer's involvement with each of them, as well as their similarities with the case on trial...[T]he Commonwealth relies on the following points of similarity:...C. Each of the four victims had been subjected to forcible rape and sodomy. D. Each of the four victims was overcome quickly...G. Each victim was found strangled by a neck ligature and with the hands tied. In three of the four cases, the neck ligature was also tied to the bindings around the hands...K. Unusually large amounts of seminal fluid were found outside the body of each victim.” [Author's note: Spencer was executed.]

"Wisconsin man gets life plus 164 years in torture-slaying case." Associated Press. May 23, 1989, http://www.apnewsarchive.com/1989/WisconsinMan-Gets-Life-Plus-164-Years-In-Torture-Slaying-Case/id-64b0d80a3bbba550

037f10fd58f2eaab. "A man convicted of torturing and murdering his sister-in-law and trying to kill his wife should spend the rest of his life behind bars, said the judge who sentenced him...Weber, 25,...was charged with 18 counts in the 1986 killing of his wife's sister, Carla Lenz, 17, and the attempted murder of his 22-yearold wife...He pleaded guilty to nine charges, including the kidnapping and firstdegree murder of Miss Lenz and the attempted murder of his wife, but pleaded innocent to charges of sexual assault and mutilation. A jury convicted him of the sexual assault and mutilation charges...Among the evidence was a tape recording describing the slaying [of his wife's sister] that Weber said he made to scare his wife but never played for her...." [Author's note: Both State and Federal courts upheld Defendant's conviction. The State Supreme Court case, State v. Weber, 163 Wis.2d 116 (Wis. 1991), https://www.courtlistener.com/opinion/2042135/state-vweber/, includes this description of the assaults on Defendant's 17-year-old sisterin-law:

The defendant described how he got his sister-in-law...to go for a ride with him...He parked the car in a secluded area. Shortly thereafter he shoved a .25 caliber pistol in her mouth-forced her to disrobe, put duct tape over her mouth, tied her wrists together, burned her nipples with a lighted cigarette-slapped her breasts and head with a board. He then pulled her out of the car, hit her several times with a plank, forced her to perform fellatio and oral-anal contact on him. He then forced a wheelbarrow handle into her vagina, another handle into her rectum and stuck fifty pins into her breast and nipple. He then used a hypodermic needle to inject lighter fluid into her breast after which she became unconscious and he 'stepped on her throat till she died." (At pp.125-126)]

"Suspect in sex crimes sought." Associated Press. Knoxville Journal, February 27, 1989. "In a boxy little house...police believe mild-mannered engineer [Defendant], perhaps under the influence of porn-fueled fantasies, assaulted young women while his wife was away. He admitted, police say, to kidnapping and assaulting three girls, killing one of them, and assaulting four others in Georgia and South Carolina. Police in five other states, including Tennessee, want to talk to him. When police searched [Defendant's] rented storage unit...they found 935 pornographic books and magazines depicting sexual bondage, horror scenes and nudity...And police said they found about 100 videotapes, some of which were of [his] sexual assaults...[Defendant]...came to authorities' attention....when a 17-year-old girl, who [had] vanished...ran to a house on [Defendant's] street. She told occupants she had been imprisoned in [Defendant's] home for four days - often in handcuffs - and that she had been sexually assaulted. Now, he's charged with 
kidnapping the 17-year-old, a 12 year-old and 15-year-old [name omitted]. The 17year-old and 12-year old survived..." [Author's note: A book entitled A Stranger in the Family: A True Story of Murder, Madness, and Unconditional Love (Naifeh \& Smith v1995) was written about this man's violent sex crimes.

People v. Bittaker, 774 P.2d 659 (1989). https://www.courtlistener.com/opinion/1179588/people-v-bittaker/). "From June through October of 1979, defendant and Roy Norris kidnapped and murdered five teenage girls in the Los Angeles area. Most of the killings involved the rape and torture of the victims. Defendant now stands convicted of 26 felony counts...Defendant was sentenced to death. His appeal is automatic. We affirm the conviction and sentence...Defendant met Roy Norris while they were inmates in state prison...The two men became friends, and frequently discussed their mutual interest in rape, and analyzed methods of abducting and raping women without getting caught...1. The testimony of Roy Norris. Norris testified for the prosecution pursuant to a plea bargain under which he pled guilty to five murders and received a sentence of forty-five years to life...(c) The murders of Jacqueline Gilliam [age 15] and Leah Lamp [age 13]...Neither defendant nor Norris was sexually interested in Lamp. Defendant set out to rape Gilliam. Learning that she was a virgin, he set up a tape recorder to record her cries during the rape. After Norris also raped Gilliam, they retied the girls, and all remained in the van overnight...The next morning defendant took Lamp up a hill, took some photographs, and left her there. Upon returning, he arranged for Norris to take a series of photographs of him with Gilliam, beginning with them clothed, then nude, then during intercourse and oral copulation. Defendant brought Lamp back to the van, and they drove into town for food and supplies. Upon their return, defendant took additional nude photographs of Gilliam...(At this point, according to Douglas, defendant tortured Gilliam. Norris does not mention torture.)... Defendant then took Gilliam out of the van and killed her, first thrusting an ice pick through her ear into her brain, then choking her. Defendant returned to the van, aroused Lamp (who had been forced to take tranquilizers to keep her quiet), and as she stepped out of the van, struck her with a sledgehammer. Defendant choked Lamp while Norris struck her with the hammer until she was dead..." [Author's note: The Court's opinion also states that included in the evidence that the prosecutor offered were "various sadomasochistic and bondage magazines found in defendant's possession.”]

Gallego v. State, 101 Nev. 782, 711 P.2d 856 (1985), http://law.justia.com/cases/nevada/supreme-court/1985/15932-1.html. "Two young womendisappeared from a shopping mall in Sacramento, California, on April 24, 1980. Their brutalized bodies were discovered...in shallow graves in remote Limerick Canyon, Nevada. The hands of both girls were trussed with an uncommon variety of macrame rope. An autopsy revealed that both victims suffered violent deaths caused by multiple blows to the head with a hammer or hammer-like object. According to the State's primary witness [Defendant's wife], defendant had her entice the two victims into a van where they were forcibly confined, sexually molested...and ultimately transported to the place of their destruction. The gravamen of [her] testimony was that [Defendant] again transmogrified his 'sex slave' fantasy into an intense, morbid reality. During the course of trial, evidence was adduced concerning similar conduct by [Defendant] in the earlier killing of two young women kidnapped from another shopping mall in the Sacramento area. The latter victims were felled by a number of bullets to the head, whereas Stacey and Karen 
had been viciously bludgeoned to death by a hammer..." [Author's note: All four of the "young women" were under age 18.]

Attorney General's Commission on Pornography: Final Report (1986), Part 4, Chapter 1 ["Victimization"], Subsection II.A.3. ["Battery, Torture"], http://www.porn-report.com/battery-torture.htm. The Commission also had received several accounts from individuals who described the use of pornography in the course of physical abuse, and who attributed the type and forms of abuse to specific pornographic materials.... [O]ne woman who reported having been sexually abused by her father from the age of three testified that he would "hang me upside down in a closet and push objects like screwdrivers or table knives inside me. Sometimes he would heat them... All the while he would have me perform oral sex on him. He would look at his porno pictures...to get ideas of what to do to me or my siblings. A woman whose father had sexually abused her from age three testified: "I have had my hands tied, my feet tied, my mouth taped to teach me big girls don't cry. He would tell me I was very fortunate to have a father that would teach me the facts of life. Many of the pictures he had were of women in bondage, with their hands tied, feet tied and their mouth taped."

\section{SEX TRAFFICKING}

Author's note: Title 22, Section 7102, of the United States Code defines "sex trafficking" [7102(10)] to mean "the recruitment, harboring, transportation, provision, or obtaining of a person for the purpose of a commercial sex act" and defines "commercial sex act" [7102(4)] to mean "any sex act on account of which anything of value is given to or received by any person." The statute also defines "severe forms of trafficking in persons" [7102(9)] to include "sex trafficking in which a commercial sex act is induced by force, fraud, or coercion, or in which the person induced to perform such act has not attained 18 years of age" and defines "coercion" [7102(3)] to include "(A) threats of serious harm to or physical restraint against any person; (B) any scheme, plan, or pattern intended to cause a person to believe that failure to perform an act would result in serious harm to or physical restraint against any person..."The term "commercial sex act" encompasses both prostitution and the production of pornography for commercial purposes. To constitute severe sex trafficking, the government does not need to prove force, fraud or coercion if the person has not attained 18 years of age.

\section{Sex Trafficking: Adult Victims}

"Woman brought to Virginia was torture victim, FBI says." Bill McKelway. Richmond Times-Dispatch, February 13, 2015, http://www.newsadvance.com/news/state/woman-brought-to-virginia-was-torture-victim-fbi-says/ article_bea726b0-b3b0-11e4-9367-1feb09877ea4.html. "An Iowa couple have been charged with sex trafficking and torture in a brutal cross-country scheme first uncovered by Virginia State Police and New Kent County authorities. New Kent officials dropped charges...against [male Defendant], 36, and [female Defendant], $31, \ldots$ as federal agents filed new charges...Starved and denied water, the woman was abducted...in Iowa and told investigators 'that she was forced to engage in prostitution in order to earn money for...food and gas on the trip,' according to federal documents. Sexual rendezvous were arranged on Craigslist..., according to the federal documents...[D]octors were able to document multiple injuries on the woman 
that were consistent with her account and included 'burns around her abdomen, groin, and back.' The burns allegedly originated from a set of keys that [male Defendant] heated over the RV's stove burner. The court documents also allege that the victim 'explained in detail how [Defendants] drove nails into her feet with a hammer.' The woman sustained multiple branding wounds and injuries consistent with having had nails hammered into her feet. Investigators recovered pictures of the victim 'nude and gagged'..." [Author's note: The Times-Dispatch also reported that the victim was "ordered to address [Defendants] as 'Master' and 'Mistress." Both Defendants pled guilty to federal sex trafficking charges.]

"Police: Woman's Vegas 'dream' smashed by sex industry torture." Mike Blasky. Las Vegas Review-Journal, September 25, 2014, http://www.reviewjournal.com/news/las-vegas/police-woman-s-vegas-dream-smashed-sex-industry-torture. "...The pimp promised a life of luxury - they'd 'get to the top together,' he said. The woman had never worked as a prostitute. But she had almost nothing to her name. She wanted to believe him...[F]our months after being conned into a life of prostitution in Las Vegas, the woman was left for dead...In addition to the numerous bruises, she had spinal fractures and severe internal injuries to her kidney, liver and spleen. The lacerations on her back and butt...were so infected that they stunk. Her middle finger on her right hand, ravaged by gangrene, needed to be amputated. The woman, malnourished to a point she lost 70 pounds, was reluctant at first to tell police who nearly killed her despite fearing that the pimp would kill her for talking, she eventually spoke...[T]he suspect, [Defendant], 28, was booked at the Clark County jail on a mountain of felony charges, including sex trafficking...The woman's story was documented in a lengthy Metro report obtained by the Review-Journal...It's a common thread - smooth-talking pimp convinces a down-on-her-luck woman he can change her life...'We call it selling them the dream,' Metro Lt. Karen Hughes said. Pimps beat their prostitutes to establish mental and physical dominance, she said. But Hughes said [Defendant's] disregard for humanity made him one of the most violent suspects she had encountered...The woman told police [Defendant] initially treated her well...But the beatings started just a few weeks later...The beatings intensified..., the woman said, after another prostitute [Defendant] recruited to the home sneaked away...[Defendant] blamed the woman for not keeping watch, she told police, and struck her in the face and body with his fists and a belt. The next month and a half [Defendant] began beating her with metal poles, wires, a wooden paddle and a chair, the report said. The wire whippings were among the worst beatings, she said, opening deep wounds...The woman told police the beatings were 'torture' and described being scalded with hot water during one attack; in another, Sharpe used waterboarding as punishment, the woman said. She said Sharpe placed a shirt on her face, forced her into the bathtub and dumped water on her face. The woman thought she was drowning and fell unconscious, she told police."

"Three Defendants scheduled to be arraigned for human trafficking, kidnapping, and torturing woman." Release. Orange County District Attorney," July 30, 2014, http://newsantaana.com/2014/07/30/three-convicted-of-human-trafficking-kidnapping-and-torture."Three defendants are scheduled to be arraigned today...[Male Defendant1], 26,...is charged with two felony counts each of torture, kidnapping, mayhem, and one felony count each of human trafficking, aggravated assault, pimping, and pandering, with sentencing enhancement and allegations for personal infliction of great bodily injury and great bodily injury...[Male Defendant2], 33,...and [female Defendant], 27,...are both charged with 
two felony counts of kidnapping, one felony count each of torture, human trafficking, mayhem, aggravated assault, pimping, and pandering, with sentencing enhancement and allegations for personal infliction of great bodily injury and great bodily injury...Circumstances of the Case [Male Defendant1] is accused of being a human trafficker/pimp who exploits women and/or children for financial gain. The victims are required to turn over all payment they receive for sex acts from sex purchasers to their pimp. Failure to follow these rules can result in deprivation of food and/or physical and/or emotional abuse. In May 2014, [male Defendant1] is accused of recruiting 25-year-old Jane Doe to perform commercial sex services for his benefit...On July 22, 2014, [male Defendant1] is accused of becoming upset with the victim and burning her with a heated glass pipe used to ingest methamphetamine while they were staying at a motel...He is then accused of using zipties to tie the victim to a chair, duct taping her mouth, and blindfolding her...On July 27, 2014, [both male Defendants] are accused of torturing Jane Doe by physically beating her, burning her multiple times with a hot electric clothing iron by placing it on her back, and tying the victim to a chair and tipping it back. They're also accused of pouring water down the victim's mouth and nose. [Female Defendant] is accused of aiding and abetting in the torture."

“The Horrific World of Online Sexual Violence Against Women." David DiSalvo. Forbes, July 1, 2012, http://www.forbes.com/sites/daviddisalvo/ 2012/07/11/special-investigation-the-horrific-world-of-online-sexual-violence-

against-women/. "The videotaped rape industry is much larger than most would think...There are multiple varieties of these films, and it is not always easy to know in which cases participants are willing (possibly actors) or victims...But from my research, two things are abundantly clear: (1) both simulated and real rape is being videotaped and shown...and (2) in many of the cases, the women have clearly been tricked into being in these films, and/or were abducted and drugged. Several of the films originate in Russia and Eastern Europe...Indeed, it appears that there's a burgeoning industry of rape films coming from this part of the world, which is.... major highway for human sex trafficking...The other major geographic region that appears to produce the bulk of these films is Southeast Asia. Staged sexual assault videos have long come from this part of the world, but the depth and brazenness of the content seems to have increased tenfold in recent years...Another category of Asian rape videos features a beautiful girl who comes to a modeling office under the auspices of competing for a modeling contract... When she comes back to the main room, the men ask that she finish the paperwork and offer her a soda while she does so. The soda is laced with a drug that causes her to pass out. When she wakes, she finds that she has been harnessed to a chair and the two men are holding video cameras. Still semi-drugged, she tries to scream but is so groggy that she can barely focus on what's happening. The men then begin ripping off her clothes and torturing her with small electronic devices placed in her vagina, all the while laughing at her muted responses. When they have finished torturing her, they remove her from the chair and throw her down on a matted floor, where she is hogtied and repeatedly raped by both men."

"The Slave and the Porn Star: Sexual Trafficking and Pornography." Robert Peters, Laura Lederer \& Shane Kelly. Protection Project Journal of Human Rights and Civil Society, (5):1-21, at 6-7, John Hopkins Univ. (2012), http://www.ifsnetwork.org/Portals/4/docs/TPP-J-HR-Civ-Socy_Vol-5_2012-wcover1.pdf. "In United States $v$. Bagley et al...the alleged victim was a young woman with a troubled childhood who suffered from mental deficiencies. She is 
referred to as ' $\mathrm{FV}$ ' in the indictment. The primary defendants, a husband and wife, took FV into their home when she was 16 years old, after she ran away from a foster home. The defendants allegedly began to sexually abuse and physically harm FV and forced her to dance at local strip clubs. They allegedly forced the victim to act as their property, and 'Edward Bagley allegedly beat, whipped, flogged, suffocated, choked, electrocuted, caned, skewered, drowned, mutilated, hung and caged FV to coerce her to become a sex slave.' The defendants forced FV to sign a slave contract that she believed bound her to act as their slave, and they had her tattooed with a barcode...Multiple other defendants communicated with Bagley regarding his activities and allegedly participated in some of his videos and photo shoots. At one point, FV even 'appeared on the cover of the July 2007 issue of Taboo, a publication owned by Hustler Magazine Group, and was the subject of a story and multipage photo spread inside'...Four defendants are being prosecuted for these actions under the forced labor and sex trafficking provisions of the TVPA, along with other serious crimes..." [Author's note: Allegations in this case are described in detail in the Superseding Indictment, at http://www.justice.gov/sites/default/files/usao-wdmo/legacy/2011/05/02/bagley_indictment2.pdf.]

"Katya's story: trafficked to the UK, sent home to torture." Amelia Gentleman. Guardian (UK), April 19, 2011, http://www.theguardian.com/law /2011/apr/19/sex-trafficking-uk-legal-reform. "When they assessed her case, British immigration officials knew that Katya, a vulnerable 18-year-old from Moldova, had been trafficked and forced into prostitution, but ruled that she would face no real danger if she was sent back. Days after her removal from the UK, her traffickers tracked her down to the Moldovan village where she had grown up. She was gang-raped, strung up by a rope from a tree, and forced to dig her own grave. One of her front teeth was pulled out with a pair of pliers. Shortly afterwards she was re-trafficked, first to Israel and later back to the UK...The Moldovan woman was first kidnapped by traffickers when she was 14, repeatedly sold on to pimps and other traffickers, and forced to work as a prostitute for seven years in Italy, Turkey, Hungary, Romania, Israel and the UK...The exhaustive account that Katya has given in court documents, explaining how she was targeted, captured and intimidated, reveals the sophisticated methods employed by gangs trafficking vulnerable women from eastern Europe, Africa and the far east. It also reveals the danger that these women are often exposed to when the British immigration service opts to remove them.... Although they recognised that she had been trafficked, immigration officials decided to remove her to Moldova...A few days after she returned home, her traffickers found her. 'They took me to a forest and I was beaten and raped. Then they made a noose out of rope and told me to dig my own grave as I was going to be killed,' Katya's court statement reads. 'They tied the noose around my neck and let me hang before cutting the branch off the tree. I really believed I was going to die. They then drove me to a house where many men were staying. They were all very drunk and took turns to rape me. When I tried to resist, one man physically restrained me and pulled my front tooth out using pliers'...Katya has been interviewed by medical and trafficking experts in preparation for the trial, all of whom found her account credible."

"Kidnap, rape and animal sex porn trial starts." Expatica News, January 1, 2005, http://www.expatica.com/be/news/country-news/Kidnap-rape-and-animal-sex-porn-trial-starts_125376.html. "The trial of two Belgian brothers, and three other people accused of kidnapping, raping and forcing women to have sex with animals for pornographic videos has opened in the Dutch city of 
Lelystad...They are charged with kidnapping, rape, human smuggling and membership of a criminal gang. Three young North African asylum seekers were kidnapped in Belgium and forced to undergo various sex acts in the farm shed, until one of the women escaped....and alerted police....[T]he three women possibly escaped a brutal death in which they would have been dismembered in front of a camera and murdered for a 'snuff' film. The gang had allegedly...made contact with people who were willing to carry out the crime."

“The Girls Next Door." Peter Landesman. New York Times Magazine, January 25, 2004, http://www.nytimes.com/2004/01/25/magazine/25SEXTRAFFIC. html. "Immigration and Customs Enforcement agents at the Cyber Crimes Center in Fairfax, Va., are finding that when it comes to sex, what was once considered abnormal is now the norm. They are tracking a clear spike in the demand for harder-core pornography on the Internet. 'We've become desensitized by the soft stuff; now we need a harder and harder hit,' says I.C.E. Special Agent Perry Woo. Cybernetworks...through which you can download and trade images and videos have become the Mexican border of virtual sexual exploitation. I had heard of one Web site that supposedly offered sex slaves for purchase to individuals. The I.C.E. agents hadn't heard of it. Special Agent Don Daufenbach, I.C.E.'s manager for undercover operations, brought it up on a screen. A hush came over the room as the agents leaned forward, clearly disturbed. 'That sure looks like the real thing,' Daufenbach said. There were streams of Web pages of thumbnail images of young women of every ethnicity in obvious distress, bound, gagged, contorted. The agents in the room pointed out probable injuries from torture. Cyberauctions for some of the women were in progress...' With new Internet technology,' Woo said, 'pornography is becoming more pervasive. With Web cams we're seeing more live molestation of children."

"Welcome to the Rape Camp': Sexual Exploitation and the Internet in Cambodia." Donna M. Hughes. Journal of Sexual Aggression, 2000; 6(1/2):1-23 (citations omitted), http://www.uri.edu/artsci/wms/hughes/rape_camp.pdf. "In October 1999, an American living in Phnom Penh, Cambodia, announced that he was adding a live bondage sex show to his Internet site...His pornography web site, 'Rape Camp,' featured 'Asian sex slaves' who were used for 'bondage, discipline and humiliation.' The women on the web site were blindfolded, gagged and/or bound with ropes while being used in sex acts; some had clothespins clipped to their breasts...Viewers were encouraged to 'humiliate these Asian sex slaves to your hearts content'...Expanded service was to feature live interactive Internet transmission of bondage sex shows from Cambodia with pay-per-view access in which customers could relay requests for torture that would be fulfilled...He claimed the women were not harmed or forced to perform the sex acts and were paid... He rationalized his 'Rape Camp' by saying, "They're selling these women anyway in prostitute houses...Once the pornographic web site came to the attention of the Cambodian Minister of Women's Affairs, Mu Sochua, she called... for him to be charged with violating a Cambodian law prohibiting sexual exploitation and trafficking of women... Although [he] faced up to five years in jail in Cambodia for violating the law on human trafficking and sexual exploitation, U.S. officials intervened...to assist him...”

Attorney General's Commission on Pornography: Final Report (1986), Part 4, Chapter 2 ["Use of Performers in Commercial Pornography"], Subsection B.3.2. [“Coercion”], http://www.porn-report.com/coercion.htm. "...It is an unpleasant, controversial, but in our view well established fact, that at least some 
performers have been physically coerced into appearing in sexually-explicit material, while others have been forced to engage in sexual activity during performances that they had not agreed to beforehand. We heard direct testimony from... The credibility of that testimony was strongly reinforced by...We also find highly credible the assertion of law enforcement officers...As one of them put it: 'Coercion comes...in the area of anal sex, which many of the models don't want to get into. It really comes into a factor in the bondage and S\&M type films. I have talked to models and I have seen films where it's quite obvious that the model had no idea as to what they were getting into. Part of an S\&M film, when they start torturing the victim, tying them, whipping them and putting cigarettes out on their body, is the showing of pain. This is what sexually excites some people...[W]e are not dealing with people that can act...T[]he pain is very real."”

\section{Sex Trafficking: Child Victims}

"Oxford exploitation trial: Guilty verdicts over child rapes." Mark Easton. BBC News, May 14, 2013, http://www.bbc.com/news/uk-england-oxfordshire-22438623. "An Old Bailey jury heard six girls were drugged and suffered sadistic abuse while aged between 11 and 15 . The court heard victims were plied with alcohol and drugs before being forced to perform sex acts. Some had also been beaten, burnt and threatened. Nine men had denied charges including rape, arranging child prostitution and trafficking between 2004 and 2012. Two were acquitted... The court heard how the men identified vulnerable girls for abuse then groomed each one of them until they were under the control of the gang. Acts of physical and sexual violence escalated into using objects to cause pain and humiliation. The court heard girls were tied up, burnt, suffocated, bitten, scratched and urinated upon. Jurors were told most of the victims chose to take vast quantities of hard drugs to deaden their senses...One of the victims described being...forced to have sex with strangers while being filmed at the age of 13..." [Author's note: $B B C$ News also reported the following:

At the heart of the prosecution was the testimony of six victims who had been targeted, groomed and ultimately controlled and sold for sex with men around the country...There were other victims...These are their stories, based on what was heard in court...GIRL ONE...Once, [two Defendants] drove her to a country park. Another four men joined them and they threatened to cut off her head if she did not perform sexual acts on all of them. She would go missing for a week... and would return covered in bruises and cigarette burns...GIRL TWO... They supplied her with alcohol and drugs, threatened her and burnt her with a lighter. [A Defendant] once threatened to have her shot...GIRL THREE ...One of the key allegations in the trial was a rape by [a Defendant] during which she thought she was going to die...GIRL FOUR...[A Defendant] groomed her and would violently rape her and threaten her...He also 'branded' the girl to signify that she belonged to him...[Two Defendants] would take her to homes...where she would be subjected to gang rapes - incidents that she described as 'torture sex'. The men would tie her up and gag her mouth with a ball to stop her cries being heard. The men would play out abuse fantasies; sometimes she was left bleeding for days...”]

\section{"Former sex trafficking victim shines light on dark underworld of Su-

per Bowl." Naomi Martin. Times-Picayune, February 1, 2013,


http://www.nola.com/crime/index.ssf/2013/02/former_sex_trafficking_victim. html. "Amid the parties and fun of Super Bowl 2013, authorities say, there is a dark underworld of girls and women being forced into the sex trade. Sitting in the festive lobby of a New Orleans hotel..., Clemmie Greenlee, a former victim of sex trafficking from Nashville, recalled being brought to cities around the South to prostitute for those attending such large-scale events...Having been abducted and gangraped by her captors at age 12, Greenlee said, she was one of about eight girls controlled by a ring of pimps, men who injected them with heroin and, at times, kept them handcuffed to beds. For trying to run away, she was once stabbed in the back. Now 53, Greenlee works at Eden House in Uptown New Orleans, the first shelter for sex-trafficking victims in Louisiana; the center opened in October 2012. 'If you don't make that number (of sex customers), you're going to dearly, dearly, severely pay for it,' Greenlee said. 'I mean with beatings, I mean with over and over rapings. With just straight torture. The worst torture they put on you is when they make you watch the other girl get tortured because of your mistake."

"Child Sold as Sexual Dominatrix for Both Online, In-Person Sessions." Release, U.S. Attorney's Office, WD Missouri, May 5, 2010, http://www.fbi.gov/kansascity/press-releases/2010/kc050510a.htm. "Beth Phillips, U.S. Attorney for the Western District of Missouri, announced that a...Missouri woman was sentenced in federal court today for the sex trafficking of her daughter...Both she and [a male] co-defendant... pleaded guilty...[The co-defendant], with the assistance of the victim's mother, obtained control of the then-12year-old girl in 2000. With her mother's knowledge and consent...[Co-defendant] sexually groomed and trained the child to become a BDSM (bondage-dominationsadism-masochism) sexual dominatrix. He did so by engaging in BDSM activities with the child himself, forcing her to engage in sexual activities with other men while he watched, and using BDSM pornography over the Internet to teach her techniques and skills to use as a dominatrix. [Co-defendant] resided in the same home as the child and her mother, who allowed [him] to engage in BDSM activities with the child and teach the child techniques...For two years, [he] sold the child...to sexually dominate men during online web sessions and in-person BDSM activities. This included, among other things, bondage, beatings, burning, and genital mutilation..."

“Child-for-sale trial gets ever more lurid." Guillermo Contreras. San Antonio Express-News (Archive), May 28, 2009. "Sex, submission, dominance and role-playing. The lurid details spilled from a federal courtroom...as a man on trial dueled with his former girlfriend about who was to blame for an alleged attempt to sell her 5-year-old daughter for sex. Lawyers for [Male Defendant], 40, argued that any mention of sex with the child was merely part of the role playing that [he] and...[Female Defendant], 25, had during phone texting sessions and online chats. But [Female Defendant], who already pleaded guilty...claimed [Male Defendant] was serious about sex with the girl and lined up a meeting with a 'sugar daddy' to pay for sex...The phone and computer exchanges were portrayed as a central part of a 'BDSM lifestyle' engaged in by the couple - bondage, dominance, submission, sadomasochism and sexual role-playing...Throughout the messages, [Female Defendant] refers to [Male Defendant] as 'sir' and asks for permission to do things. [Female Defendant], a former stripper...testified that it illustrates how she was the 'submissive' and [he] the 'dominant' in the relationship. The messages also showed jurors that [Defendants] talked about how to bring [her] two daughters into their lifestyle, and discussed plans to have [Female Defendant] have sex with other men 
for money." [Italics added] [Author's note: A jury found the male defendant guilty of aiding and abetting his former girlfriend in an attempt to sell her 5-year-old daughter for sex.]

"The Evil Behind the Smiles." Nicholas Kristof. New York Times, December 31, 2008, http://www.nytimes.com/2009/01/01/opinion/01kristof.html. “...Sina is Vietnamese but was kidnapped at the age of 13 and taken to Cambodia, where she was drugged. She said she woke up naked and bloody on a bed with a white man....who had purchased her virginity...Sina mostly followed instructions and smiled alluringly at men because she would have been beaten if men didn't choose her. But sometimes she was in such pain that she resisted, and then she said she would be dragged down to a torture chamber in the basement. 'Many of the brothels have these torture chambers,' she said. 'They are underground because then the girls' screams are muffled.' As in many brothels, the torture of choice was electric shocks. Sina would be tied down, doused in water and then prodded with wires running from the 220 -volt wall outlet. The jolt causes intense pain, sometimes evacuation of the bladder and bowel - and even unconsciousness... After the beatings and shocks, Sina said she would be locked naked in a wooden coffin full of biting ants. The coffin was dark, suffocating and so tight that she could not move her hands up to her face to brush off the ants. Her tears washed the ants out of her eyes."

"Ohio man arrested, charged with attempting to purchase two children for sexual torture." Office of Attorney General, Jacksonville, FL, July 25, 2007. "An Ohio man was arrested on felony charges that he approached an undercover investigator online and offered to pay to act out his sexual perversions with children, Attorney General Bill McCollum today announced. [Defendant] was arrested by authorities with the Child Predator Cybercrime Unit after he flew to Miami, believing he was going to meet a mother of two girls, ages nine and 12 years old, and would pay the woman $\$ 500$ to forcibly submerge the children under water until they became unconscious[]. During multiple internet conversations, [Defendant] told the woman, an undercover agent with the United States Secret Service, that 'dunking' was his particular form of sexual gratification...He claimed he 'liked watching the bubbles' and went on to send the undercover agent explicit images of child torture as examples of what he proposed to do...Sexual abuse of a child includes any sadomasochistic abuse...for the purpose of sexual gratification."

"Police catch up with cyber porn selling syndicate," China Post, February 1, 2002. "Three Taipei men were arrested by officials from the Criminal Investigation Bureau (CIB) yesterday for hosting a pornographic Web site...CIB officials said...the trio...have been using the site on the Internet to sell $X$-rated video discs...Upon viewing some of the discs [Defendant1] sold, investigators found they were mostly naked photographs of unidentified local women, with some of them underage minors, depicted in cruel and painful sadomasochistic sessions. Since many of the females featuring in the VCD's appeared to be rendered unconscious by drugs and held against their will, police suspected that [Defendant1] and his group probably had either tricked or forced their subjects into being in the film....When arrested [Defendant1] told police that all of the pornographic video discs he sold were provided by a former friend..." [Italics supplied]

"British link to 'snuff' videos." Philip Willan. Guardian (UK), September 30, 2000, http://www.theguardian.com/uk/2000/oct/01/ameliagentleman.philiwillan. "Britain is a key link in the biggest ever international investigation into the 
production and supply of paedophile 'snuff' movies - in which children are murdered on film...The key suspect..., a Russian who was arrested last week in Moscow for distribution of thousands of sadistic child porn videos and pictures, was traced following the seizure of his products from British paedophiles...Last week Italian police seized 3,000...videos on their way to clients in Italy, sparking an international hunt for paedophiles who have bought his products. The Italian investigators say the material includes footage of children dying during abuse. Prosecutors in Naples are considering charging those who have bought the videos with complicity in murder. They say some may have specifically requested films of killings. British authorities yesterday confirmed that scores of [Russian Defendant's] videos... have been found in the UK. They are concerned that 'snuff' movies in which children are killed may have also been imported...'We have seen some very, very nasty stuff involving sadistic abuse of very young children, but actual deaths on film takes it a whole step further. That is very worrying,' said one senior customs officer this weekend."

“Cops: Pimp a monster - Say he tormented underage hookers." Bill Farrell et al. New York Daily News, August 13, 1997, http://www.nydailynews.com/archives/news/cops-pimp-monster-tormented-underage-hookers-article-1.770954. "An accused [22-year-old] Brooklyn pimp used torture and intimidation to keep his stable of underage girls including an 11-year-old runaway in line, police said yesterday. [Defendant] preyed on runaways and troubled teens, forcing them to sell their bodies, police said. And when they didn't bring in enough money, there was hell to pay...A 14-year-old who worked for [Defendant] for several weeks told police he once tied her to a basement pole, poured baby oil on her, whipped her with an extension cord and burned her with cigarettes before carving a Q on her arm with a razor. A 17-year-old...told police he beat her with a rope for taking too long with a 'client.'...[Defendant] was...charged with multiple counts of rape, sodomy, sexual abuse and...two counts of assault and promoting prostitution."

"IBM Exec charged with sex torture of boys." Bill Hoffmann. New York Post, August 17, 1989. "A longtime IBM executive was charged...with the gruesome sexual torture of 10 young boys in his Westchester home over the past five years. [Defendant] electrically shocked and tied fishing weights to the boys genitals and also recorded their desperate screams of pain on tape, said Westchester District Attorney Carl Vergari. [Defendant] also photographed some of the horrors and sold them as child pornography, Vergari said...Vergari said that since 1985, [Defendant] had lured neighborhood kids and the children of his adult friends to his house. Once inside, he would sodomize and torture them and make them commit sex acts on each other." [Italics added]

Attorney General's Commission on Pornography: Final Report (1986), Part 4, Chapter 1 ["Victimization"], Subsection II.A.3. ["Battery, Torture”], http://www.porn-report.com/battery-torture.htm. “...One witness before the Commission described how women and young girls were tortured and suffered permanent physical injuries to answer publisher demands for photographs depicting sadomasochistic abuse. When the torturer/photographer inquired of the publisher as to the types of depictions that would sell, the torturer/photographer was instructed to get similar existing publications and use the depictions therein for instruction. The torturer/ photographer followed the publisher's instructions, tortured women and girls accordingly, and then sold the photographs to the publisher. The photographs were included in magazines sold nationally in pornographic outlets." [Author's note: The U.S. Supreme Court upheld a state law 
prohibiting distribution of child pornography in 1982, and it wasn't long after that Congress enacted legislation to prohibit distribution of child pornography. Prior to the early 1980s, child pornography was openly sold in "adult businesses.”]

\section{MAINSTREAMING OF SADOMASOCHISM}

\section{In General}

"Breathless: Has Fifty Shades of Grey Made S\&M too Mainstream?" Karley Sciortino. Vogue, February 12, 2015, http://www.vogue.com/ 10572593/fifty-shades-of-grey-valentines-day-breathless-karley-sciortino/. "This Valentine's Day, lovers the world over will open heart-shaped boxes to find, instead of chocolate, a blindfold and matching whip. 'I love you, baby,' the card will read. 'Here's a leather paddle-with special holes to reduce air resistance and increase pain!' BDSM, as you most likely already know, has gone mainstream. The theatrical release of Fifty Shades of Grey is this weekend, and the Internet is teeming with articles with titles like...Of course, E.L. James's Fifty Shades trilogy (more than 100 million books sold worldwide) played a big part in all of this. But the popularization of BDSM (bondage/discipline, domination/submission, sadism/masochism) is also just the inevitability of the Internet. Today, anyone with a unique or extreme sexual persuasion can easily find people like themselves and create communities. People have always wanted to have adventures, and technology now facilitates them..."

“...Why S\&M will never be fully accepted.” Will Saletan. Slate, March 4, 2013, http://www.slate.com/articles/health_and_science/human_nture/2013/ 03/bondage_dominance_submission_and_sadomasochism_why_s_m_will_ never_go_mainstream.html. "Is S\&M going mainstream? It looks that way...Sales of books and equipment have increased. So has attendance at BDSM events. BDSM-related Internet searches (domination, master, sex slave, sadism) went up 70 to 80 percent. College groups devoted to 'kink,' largely BDSM, gained official recognition...Pillars of the media establishment-ABC, Fox News, the New York Times-are exploring the rise of kink in unflinching detail. Political advocates for BDSM see themselves as successors to the gay rights movement...They call themselves 'sexual minorities' and depict kink as a 'sexual orientation.' They seek 'legitimacy' by bringing BDSM 'into the mainstream eye.'...They wonder, according to the Times, whether 'they are approaching a time when they, like the LGBT community before them, can come out and begin living more open, integrated lives.' Don't count on it."

“A Hush-Hush Topic No More.” Matt Haber. New York Times, February 27, 2013, http://www.nytimes.com/2013/02/28/fashion/bondage-domination-andkink-sex-communities-step-into-view.html. "But surely in part because of the blockbuster success of E. L. James's 'Fifty Shades of Grey' trilogy...people who are drawn to power exchange in sexuality and may refer to themselves as kinky are finding themselves in the spotlight as never before. In February, 'kink,' a documentary...had its premiere at the Sundance Film Festival. (The Hollywood Reporter called it "a friendly film about lots of seemingly reasonable people who do terrible things to each other on camera for money.")...On Showtime's 'Shameless,' Joan Cusack plays a kinky mother trying to manage the enthusiasm and pricey toy collection of her younger lover. And some real-life kinksters...are wondering if they 
are approaching a time when they, like the L.G.B.T. community before them, can come out and begin living more open and integrated lives."

“Masochism Finally Gets Even." Sara Boxer. New York Times, January 27, 2001, http://www.nytimes.com/2001/01/27/arts/masochism-finally-gets-even. html. "You may think that sadism and masochism are equals. But among scholars they are not... But masochism is getting even, if the last Modern Language Association meeting is any indication...It has even become a matter of national pride."

"Rehabilitating a Monster." Roger Shattuck. New York Times Book Review, March 31, 1996. "Our restless culture propels itself as much by revivals as by new discoveries...The process of revival goes on even while we're not looking. During the 20 ${ }^{\text {th }}$ century, we have been kept busy with two hot world wars and one cold one, and with the rise of movies and television. During that period, a few critics set out to rehabilitate a malodorous $18^{\text {th }}$ century writer...The revival of the Marquis de Sade, I believe, may turn out to be the most significant and insistent revival of the $20^{\text {th }}$ century, unless some of us resolve to challenge it. Sade confronts us with the model case of how we have blurred the distinction between literature and pornography...It took only three generations of men and women of letters to transform an aristocratic debaucher of minors and advocate of moral mayhem into a cultural hero...Simone de Beauvoir asks, "Must we burn Sade?" The answer is no...But let us not glorify and celebrate his advocacy...We have enough commercialized sexual violence without this vicious evangelist...I don't believe we want our grandchildren reading to be reading Sade along with Austen, Dickens, Tolstoy and Willa Cather...”

“Ordinary People: S\&M is suddenly everywhere...." Melinda Blau. New York, November 28, 1994, https://books.google.com/books?id=XeMCAAAAMBAJ\&pg=PA38\&lpg=PA5\&ie=ISO-8859-1\&output=html\&hl=en. "For the vast majority of people...S\&M may still seem an alien presence. But... it's already everywhere: in fashion, on TV, in the movies, on the best seller lists, on magazine racks, on the Internet. Madonna, most agree, is S\&M's first cultural ambassador...But she was only the start...”

“Chain of Command." David Friedman. New York Newsday, July 12, 1993. "Something weird is happening, all right: the kinky world of sadomasochism...is slithering out of the shadows and into the light...In 'Body of Evidence,'...Madonna turned Wilhelm Defoe into her love slave by pouring hot candle wax on his stomach. Sharon Stone opened 'Basic Instinct' by tying her lover to the bed. Even afternoon soaps have hopped on board: 'One Life to Live' recently featured a storyline involving a couple engaged in high-camp bondage and spanking. Last fall, the dominatrix look dominated the Paris fashion runways - and the November cover of Cosmopolitan, which ran a four-page 'S\&M primer' inside. Madonna's...book Sex...became an instant best seller...In 1803, the Marquis de Sade died alone and despised...Were he alive today, he'd be sitting on a stool next to Regis and Kathie Lee."

"S\&M out of the closet, into chains." Dana Kennedy (AP). Bay City Times, December 19, 1992. "The Marquis de Sade died alone and disgraced in a mental asylum in 1803...But were he alive today, the marquis might be enjoying the spoils of multimillion dollar book contracts and movie deals...[S]adomasochism appears to be gradually moving into the mainstream of American culture...It has gotten a boost from Madonna, whose S\&M-themed book, 'Sex,' and accompanying CD, 'Erotica,' are on the book and record best-seller lists. Madonna has shone the brightest light of S\&M, but its influence is being seen in movies, fashion, music, 
magazines and even on day-time soap operas...Bondage-style clothes and accessories dominated many fashion show runways this fall...The September Vogue had a layout, 'Woman in Chains.'...A...rap group uses the name House of Pain... a...heavy metal group is called Pro-Pain...Photographer Robert Mapplethorpe and performance artist Grace Jones have delved even more deeply into S\&M than Madonna... Books like 'The Story of O,'....and... movies such as '91/2 Weeks'...have maintained the thread of [S\&M]."

"S\&M Passion and Pain are all the rage in era of unsafe sex." Andrea Peyser \& Miguel Garcilazo. New York Post, October 19, 1992. "In case you've been asleep, S\&M is the hottest new craze on a Saturday night. Spankings, Spike heels, Bondage, Leather, Public Humiliation - the dank dungeon has emerged into the light. It's everywhere, and everyone seems to be doing it...Just take a look at September's...Vogue magazine. There on its...pages - women in chains...Madonna, this very week, unties her long-awaited bondage book, 'Sex' - bedtime reading to go with her whips-and-chains video, 'Erotica.'...For something really kinky, try...MTV. Babes in leather hot pants and chains gyrating to 'Hurts so Good.'...'Sex in the '90s is outercourse, not intercourse,' says Richard Kunis...'Unfortunately, because of AIDS, the dominance business has risen 90 percent,' reports Leda, head mistress..."

\section{Advertising/Fashion/Magazines}

“Taut couture.” Alev Aktar. New York Post, March 4, 2015. “...They're just the latest stars to don once-taboo latex clothing, which is moving out of the dungeon as 'Fifty Shades of Grey' gets closer to the $\$ 500$ million in global ticket sales. 'I'd like to think that latex has become a mainstream fashion fetish in part due to the popularity of 'Fifty Shades,' says Joe Zee, editor-in-chief of Yahoo Style...Sales of the sexy curve-hugging clothes are booming. The Baroness, a New York dominatrix, and latex designer...says sales of her provocative pieces have swelled...Shoppers, include 'people who aren't really into latex at all, but who've seen the movie, read the books or are looking to spice up their lives,' she says.”

“Madonna tries out a new 'gag,' New York Post, December 1, 2014. "Who's that girl? Even Madonna is tough to recognize with her face obscured by a bondage-style mask in this photo for Interview magazine."

“Alba twists young voters' arms." Oren Yaniv. New York Daily News, September 12, 2008. "Young people of America: You're bound to vote this year! Sexy Jessica Alba appears wrapped in shiny black tape over her mouth and chest in a provocative new ad urging young people to register to vote...The S\&M-inspired photo of Alba is part of a nonpartisan drive by the nonprofit group Declare Yourself, founded by TV producer Norman Lear to encourage voting among people ages 18 to 29...[Alba] told People magazine she was fine with being shown muzzled, bound and looking away in despair. 'People respond to things that are shocking,' she said."

"Agent Provocateur ad was 'offensive and pornographic." Jules Grant. Brand Republic (UK), February 11, 2004, http://www.brandrepublic.com/article/201964/agent-provocateur-ad-offensive-pornographic. "A kinky ad for upmarket lingerie brand Agent Provocateur has been slated as 'offensive, pornographic and degrading to women' by the advertising watchdog and was also considered to condone sexual violence and strangulation. The ad...showed a woman, 
who was wearing black leather gloves and lingerie, sitting astride another woman, who was lying on her back. The woman wearing gloves was holding a stocking that was stretched around the other woman's neck. Agent Provocateur claimed that it believed the ad promoted women as being in control of their own sexuality and that the 'sexual playfulness depicted was intended to be tongue-in-cheek."

"Sexy de Sade: Versace dress is nice and naughty." Denise Flaim. New York Newsday, September 17, 2003. “The Marquis de Sade does Swan Lake. That's a good a way as any to describe this season's hot dress...Versace's 'corset' dress...manages to be naughty and naïve...Beyonce opted to wear the short chartreuse version to the MTV Movie Awards...Salma Hayek wears it on the cover of this month's InStyle magazine...[W]hen fledging Vegas magazine decided to put Heidi Klum on the cover of its inaugural...issue, she was laced into the chartreuse gown...It didn't look like much just hanging there,' [magazine's art director] admits. 'But as soon as Heidi stepped into it, it was like slipping Cinderella into the slipper.' And unspoken is the likelihood that a randy Prince Charming has some handcuffs waiting in the pumpkin coach.”

"A Walk on the Wobbly Side." Penelope Green. New York Times, September 15, 2002, http://www.nytimes.com/2002/09/15/style/a-walk-on-the-wobblyside.html. "The most ubiquitous example of this fall's bondage footwear is the black velvet lattice-laced five-inch stiletto sandals...They seem to scream for dominatrix wear, but...the YSL sales associate who fitted me into the shoes on Thursday, did not suggest pairing them with rubber or skin.”

“Dominatrix 101: In Ms. Taurel's class the discipline is tough." Merrill Markoe. Vanity Fair, Sept. 1993. "Your education does not to have to end at graduation. That is why I have signed up for a Learning Annex class taught by internationally known Ava Taurel, whose blurb in the course catalogue asks, 'Do you want to learn how to make big money in a safe, legal profession that will never leave you bored? Become a Dominatrix...”

“Chic or Cruel?" James Servin. New York Times, November 1, 1992, http://www.nytimes.com/1992/11/01/style/chic-or-cruel.html?pagewanted=2.

“The tag on Cindy Crawford's garment rack read, 'Cindy Sado-Maso.' Presumably, it referred to the Gianni Versace ensemble hanging beneath it, a mechanically correct harness-bodice paired with a studded leather skirt... That night...a transformed Ms. Crawford stood behind Christy Turlington, who wore her own version of the Versace whip-lady look. It was mid-September, and the occasion was 'Rock and Rule,' Mr. Versace's first New York show in 15 years...On Thursday, when the Fashion Institute of Technology unveils 'Gianni Versace: Signatures' a 15-year retrospective..., the 46-year-old designer's dominatrix look will take center stage. No longer relegated to the back room anywhere, S \& M has surfaced as the couture esthetic, embraced by supermodels and society ladies alike. Pushed along by Madonna's 'Erotica' and 'Sex' one-two product punch, leather is everywhere. Tabloids have been running three-day installments on S \& M life styles and S \& M gear: how to wear it, where to buy it...Hardly new and hardly the domain of Mr. Versace alone, S \& M entered the fringes of fashion in the 70's, when black leather biker jackets and studded pants enjoyed a wave of popularity..."

Arts 
“Mapplethorpe's S\&M art no longer so shocking." Will Higgins. IndyStar, October 10, 2014, http://www.indystar.com/story/life/2014/10/10/mapplethorpes-sm-art-longer-shocking/17055587/. “...In 1990 Robert Mapplethorpe’s photographs - not all of them, just the graphic, guy-on-guy S\&M ones - were so shocking the cops came. Police actually raided an art museum...On Friday an exhibit of [his] photographs went on display at Indiana University's Grunwald Gallery...There were no police raids, though...The controversy apparently has faded...Sexuality of any kind raises fewer eyebrows, said Betsy Stirratt, the Grunwald's director. 'With the prevalence of pornography online, anyone can take a look... Mapplethorpe, who died of AIDS in 1989,...took elegant photographs of flowers, and of celebrities...But he is best known for photographing gay sadomasochistic practices and for partaking in them...Still, the photos are pretty shocking with their depictions of seemingly painful and degrading sex acts (Mapplethorpe insisted it was consensual).”

"Film Review: Kinkiness and piercing, branding and flogging." Stephen Holden. New York Times, December 11, 1998. "Body artist, extreme masochist, H.I.V.-positive gay man,...[and] one time grant recipient from the National Endowment for the Arts...Ron Athey has turned his life into the most radical kind of performance art...In one he is ecstatically tormented with a crown of thorns consisting of hypodermic needles that spill blood across his face as they are inserted into the skull...This is a movie that is...not for the squeamish or...sexually prudish. In addition to the blood-smearing, the film offers a methodical catalogue of advanced sexual kinkiness, with scenes of piercing, bondage, branding, flogging, enemas and dildos."

"No Pain, No Gain." Guy Trebay. Village Voice, November 11, 1997. "Sade is in the ascendant...Bob Flanagan, the performance artist who styled himself a 'Supermasochist'...did more than anyone since Sacher-Masoch to uncloset the pleasures of kink. Pierced, flogged, gagged, and mummified...Flanagan found few things more pleasing than expounding on how 'hammers, clothespins, padlocks, eyebolts, thumbtacks, staple-guns and alligator clips' got him [sexually aroused]. [Author's note: The New York Post (Johnson, 1994) reported that the New York State Council on the Arts, knowing of Flanagan's upcoming exhibit, provided a grant to the New Museum.]

“Painful Television.” Kate Bornstein. Bay Area Reporter, April 16, 1992. "I was able to preview most of the videos in the upcoming San Francisco Cinematheque program featuring works by...Both artists will be present at a April 23 San Francisco Art Institute screening... Nancy's Nightmare features a slick SM scene, one women whipping another woman in bondage to the accompaniment of 'These Books Are Made for Walking.'...

\section{Books}

"From posh private school student to dominatrix." Tricia Romano. New York Post, October 28, 2013, http://nypost.com/2013/10/28/smitten-with-thewhip-from-private-school-to-dungeon-mistress/. "She went to school among the New York elite, but Alexis Lass later rebelled against her life of privilege by becoming a whip-wielding dominatrix. She tells her story and reveals why every woman should give it a try...Her book...is out now, revealing secrets she learned on the job. Here, she tells The Post her story." 
“Coming-of-age Stories by Women Raunchy in Flavor." Tara Weiss. Hartford Courant, November 16, 2004, http://articles.courant.com/2004-11-16/features/0411160118_1_bentley-older-men-sexual. “...The author wrote the novel, a story of a 16-year-old who engages in all types of sex with groups of older men and women, when she was 16 . It became an overnight sensation in Italy...and was recently translated into English and several other languages...It's a story of older men who pressure the main character...into bizarre sexual exploits that involve blindfolds and sadomasochism.”

“Puppy Papers: A Woman's Life and Journey into BDSM." Puppy Sharon \& Steve Toushin. Wells Street Publishing 2004. [Author's note: Book advertised on Target.com]

"Rehabilitating a Monster." Roger Shattuck. New York Times Book Review, March 31, 1996.

"Shock Appeal / Who Are These Writers, and Why Do They Want to Hurt Us?..." Michael Silverblatt. Los Angeles Times, August 1, 1993. http://articles.latimes.com/1993-08-01/books/bk-21466_1_young-writers. "Part of the attraction of transgressive writing may be that the trappings of sex that previously seemed dangerous--leather, whips, tattoos, brandings, chains--have become a kind of adornment, an adjunct to the new safe sex."

“Naughty and Rice." Frank DiGiacomo. New York Post, November 24, 1992. "Like sister sensualists, they both sat atop the New York Times best-seller lists for two weeks: Anne Rice...with the latest adventure of her literary alter ego, the erotic, sadistic and sharp-toothed Lestat de Lioncourt, had been joined by Madonna...and her 'Sex' book alter id, the erotic, sadomasochistic and gold- toothed Dita Paria...She admits that she's fascinated with Madonna's foray into pornography...About the time that Madonna was singing 'Like a Virgin,' Rice was releasing, as Roquelaure, 'Beauty's Release,' the first of an X-rated S\&M-heavy Sleeping Beauty-esque trilogy. [Author's note: According to the Post article, Rice wrote a "series of hard-core pornographic novels under the pseudonym of A.N. Roquelaure.”]

"Increasing our dirty-word power: Why yesterday's smut is today's erotica." Walter Kendrick. New York Times Book Review, May 31, 1992, http://www.nytimes.com/1992/05/31/books/increasing-our-dirty-word-powerwhy-yesterday-s-smut-is-today-s-erotica.html. "A fair number even highlight sadism, masochism and bondage, practices that the mainstream used to regard as fit only for marginal publishers and readers."

Films

"Why is there so much violence against women? The rising tide of sadistic movie violence against women...." Natasha Walter. Guardian (UK), May 19, 2014, http://www.theguardian.com/film/2010/jun/03/women-violencekiller-inside-me-feminism. "Michael Winterbottom's new film, The Killer Inside $M e$, has achieved a certain notoriety for its rapt attention to the murder of its female leads. It's particularly the death of a prostitute, Joyce, played by Jessica Alba, which has divided viewers...I was almost overwhelmed during the scene. It's tough watching a woman whimpering 'Why?' as her eye is punched out of place and her bones crunch...It's true that his film's explicit violence is not unique. Yes, if you go 
to see The Killer...you will be exposed to the spectacle of a woman being punched to death, with lingering shots of her bruised face. You will also see another heroine, Amy, played by Kate Hudson, killed in a similar way, and hear her struggling for breath as she slowly dies on the floor...Violence has long been a staple of mainstream film-making, and filmgoers have been shuddering over the murders of women for generations, from Psycho to American Psycho. But over the past few years, violence against women, in particular, has become ever more forensically detailed...It is not the first time this year that I have found myself feeling sickened by the flayed female flesh presented by a mainstream film. When I went to see The Girl With the Dragon Tattoo, I found myself wondering why it is that our entertainment seems to rely so much on the fascinated depiction of women's scarred and bruised bodies. The assumption is now - and it seems to be correct - that audiences are happy to watch their heroines being beaten and gagged, and to stare at explicitly rendered photographs of women cut and splayed and killed."

“Mainstreaming mutilation...?” Carl Kozlowski. Washington Times, April 5, 2013, http://www.washingtontimes.com/news/2013/apr/5/coarsening-culturedeepens-mainstream-release-sam-/. “The Evil Dead' (1981), Mr. Raimi’s first fulllength feature, was so mercilessly violent that it was unrated upon its U.S. release and eventually branded NC-17...One might expect that with 30 more years of life experience, mainstream acceptance and a longtime marriage with five children, Mr. Raimi would look back on that movie as an early aberration. Instead, he is an executive producer and the driving force behind the big-budget remake 'Evil Dead,'... About 90 percent of the new film's running time consists of finding brutal and bloody ways to kill a person, including shotgun blasts, nail guns, broken mirror shards, strangulations, drowning, electrocution, burning and live burial. I haven't even mentioned the dungeon full of rotting cat corpses hanging from the ceiling, the dog that has its throat slashed, the moving tree branches that violate a woman (don't ask), and the numerous forced or accidental amputations along the way. The more blood spewed, the more the audience at a Tuesday night preview screening applauded and cheered...What does it say about us as a people that such depictions of hatred and suffering are considered acceptable for an $\mathrm{R}$ rating - and, thus, wide theatrical release - by the [MPAA], upon which many rely to give warning of objectionable content?”

“From Sadism to Kitsch: Pollygrind Film Fest Wrap-Up, Part 1.” Josh Bell. Las Vegas Weekly, October 13, 2011, http://lasvegasweekly.com/ae/ film/2011/oct/13/sadism-kitsch-pollygrind-film-fest-wrap--part-1/. "This year's edition of the Polly Grind film festival sprawls across 10 dayst...One thing that [festival organizer] Freeman does really well is challenge his audience, programming not only campy horror B-movies...but also extreme, underground and avant-garde films. The two that he insisted I watch...both fall into that category....You can't say the same for The Bunny Game, a nasty, plotless and nearly dialogue-free wallow in sadism, featuring a demented trucker abducting a hooker and brutally torturing her for nearly the entire movie. It's supposedly inspired by writer/star Rodleen Getsic's real-life experiences...that doesn't make it a worthwhile movie."

"Sex, sadism and torture: The not-so-funny games...." Jamie Portman. Vancouver Sun, February 24, 2009, http://www.vancouversun.com/entertainment/movie-guide/sadism+torture+funny+games+actress+Naomi+Watts/ 1324649 /story.html. "Naomi Watts 'seems to prefer roles that push her to the limits of degradation.' Such was the judgment...of Dana Stevens, film critic for the online Slate magazine...Stevens was commenting on Watts's involvement 
in...Funny Games, an item...soaked in sadism...MTV critic Shawn Adler...called it 'the most nihilistic, depraved, sadistic torture flick imaginable.'...With Funny Games now out on DVD, the 40-year-old Australian remains unrepentant about her involvement in a story about a pair of young male psychopaths who invade an idyllic summer home and torture and murder Watts, her husband (Tim Roth) and their child...[H]ow does she react to the thought of her children one day seeing the endless degradation to which her character in Funny Games is subjected - beginning with the scenes in which she is bound, gagged, and forced to strip before the torture begins?"

"When gory movies are torture to watch...." Steven Rea. Seattle Times, June 14, 2007, http://www.seattletimes.com/entertainment/when-gory-moviesare-torture-to-watch/. “In 'Hostel: Part II,'...actress Heather Matarazzo plays a gawky American coed, abducted by...sickos for the sole purpose of mutilation and murder. In one of the hotly anticipated sequel's signature scenes..., the actress is bound, gagged and hung upside down, naked, in a terror chamber. Then she's poked and pried with a sickle. Flesh is slowly carved open. Finally, the blood disgorges in gallons. 'Once the blood started flowing it was unbelievable,' says Eli Roth, like a proud papa, about the staging of that scene...Roth - with the enabling of the MPAA ratings board, which, after some give-and-take with the director, gave the movie an R rating - has pushed the envelope. No, he's punctured the envelope. And the contents - entrails, organs, severed heads - have gushed out, flooding the multiplexes...But his new release, which he predicts will be remembered as 'the most violent R-rated movie ever to hit theaters,' wasn't any kind of fun for me. The scares weren't cathartic. The gore wasn't deliciously, devilishly over-the-top. It was toxic...And is there some demented dude sitting a couple of aisles over who's going to take the explicit carnage depicted in 'Hostel: Part II' - rape, garroting, a circular saw to the face - and use it as an instructional tool?"

"Rise in torture scenes raises red flags." Greg Braxton. Los Angeles Times , February 11, 2006, http://www.boston.com/ae/movies/articles/2006/02/11/ rise_in_torture_scenes_raises_red_flags/?page=full. "In the first hit film of the year, screaming, helpless young people are brutalized by power tools and blowtorches wielded by gleeful tormentors... A principal character in a big-screen political thriller has his fingernails ripped out with pliers. The wisecracking hero of another thriller is traumatized by electrodes attached to his genitals. Increasingly, producers of movies and TV series are bringing the pain to mainstream fare - highlighting sadism, torture, brutality...all in the name of entertainment...'Marathon Man,' 'The Silence of the Lambs,' 'Lethal Weapon,' 'The Deer Hunter,' 'Braveheart' and 'Reservoir Dogs' are among the popular and critically acclaimed films...that have made audiences cringe with extended scenes of torturers inflicting pain...Torture scenes are featured in mainstream movies such as 'Syriana' and 'Kiss Kiss Bang Bang' and play a starring role in...'Hostel' and the 'Saw' franchise...'Hostel' features young travelers lured to a seemingly pleasant...hotel, where they wind up in an abandoned dungeon/warehouse and are stripped, shackled to chairs, and offered up to wealthy, bored men paying exorbitant sums for the thrill of maiming and murdering them with blowtorches and power tools."

“Awful murder flick not worth film it's shot on." Debra Birnbaum. New York Daily News, January 7, 2005. “'Murder-Set-Pieces' aspires to be a highly stylized exploration of the mind of a serial killer. But it is nothing more than a gory...snuff film, reveling in it own shock value as women are stabbed, strangled, raped and mutilated in every conceivable...ways...From then on, he proceeds on a 
one-man killing spree through the brothels of Las Vegas, brutally eliminating prostitutes and call girls with any and every weapon in his arsenal - straight razor, chainsaw, nail and cross without attracting the attention of even one cop..."

"Nicole ruffs it." Megan Lehmann. New York Post, May 20, 2003. “...In her new film, 'Dogville,' the Oscar-winning actress [Nicole Kidman] is physically violated, verbally abused and forced to wear an iron dog collar attached to a heavy chain and wheel."

"Kinky and Cruel Goings-On in the Conservatory." Stephen Holden. New York Times, March 29, 2002, http://www.nytimes.com/2002/03/29/movies/film-review-kinky-and-cruel-goings-on-in-the-conservatory.html. "...Erika [Isabelle Huppert] is a compulsive voyeur who frequents pornographic bookstores and prowls drive-in movies to spy on couples having sex in cars. At home, behind closed bathroom doors, she practices genital self-mutilation... The floodgates open when Erika unexpectedly finds herself ardently pursued by a handsome, worshipful younger student, Walter Klemmer [Benoit Magimel]... Erika is unable to give herself to Walter in any conventional fashion...Yet he remains infatuated (or maybe just curious) enough to keep playing along. Erika insists Walter...follow to the letter a long and detailed set of instructions in which he is to subject her to bondage, pain and humiliation."

“Leo Lashed for 'Psycho' role.” Su Avasthi. New York Post, May 21, 1998. "Leonardo DiCaprio's decision to play an ultra-sadistic killer in the upcoming movie, 'American Psycho,' has been blasted by...[t]he National Organization of Women...[which] criticized the casting of DeCaprio in the film version of Bret Easton Ellis' grisly and controversial 1991 novel because the 23-year-old star...has such a massive following among teenagers...[T]he book details crimes so gruesome and despicable that they make madman Hannibal Lechter of 'The Silence of the Lambs' look like a cherubic choirboy in comparison. In some of the most graphic and chilling scenes meticulously detailed in the book, the psycho Patrick Bateman: Nails a woman's limbs to a board with a staple gun before raping and murdering her...Slices out women's tongues and cooks them." [Author's note: DiCaprio turned down the role.]

“Tie Me Up' Bound by Ugliness." Elfrieda Abbe. Milwaukee Sentinel, June 29, 1990. "Spanish director Pedro Almodovar, with his graphic images of sex and violence and his focus on sexual obsessions and perversities, has shown the ability to persuade audiences to suspend moral judgment...The only thing his new film 'Tie Me Up! Tie Me Down!" sheds light on is a cruel nature that borders on sadistic. While Almodovar plays it as a dark, romantic comedy, there is little to laugh about in the movie's narrative...Ricky (Antonio Banderas) pursues a porno queen...with whom he had a brief sexual encounter several years earlier. His obsession leads him to kidnap the actress... and hold her hostage in her apartment. He breaks into her apartment, ties her up and gags her, with the idea that if she gets to know him she will fall in love with him...The movie takes a real evil turn when Abril falls in love with her captor. The message is here is that women love and need brutality."

"Is Brian De Palma-Crossing the Line between Art and Pornography?" Nina Darnton. New York Times, November 18, 1984, http://www.nytimes.com/1984/11/18/movies/on-brian-de-palma-crossing-the-line-betweenart-an-pornography.html?pagewanted=3. "Brian De Palma...has done it again. In 'Body Double,' he...has attracted a great deal of attention - and controversy. Mr. De Palma's choice of murder weapons has graduated over the years from an icepick in 
'Murder a la Mod' to a razor in 'Dressed to Kill,' to a chainsaw in 'Scarface' and now to an electric drill. In the 'Body Double" murder scene an intruder stalks a beautiful woman, whom we have seen doing an erotic masturbatory dance, and impales her with an electric drill....It is vintage De Palma gore and it will reaffirm opinion of many observers that the filmmaker has crossed the line that separates art from pornographic titillation. For some, Mr. De Palma's movies are distinguished from 'slice and dice films' such as 'The Texas Chainsaw Massacre' or the 'Halloween' movies by their artistry....For many others, however, his films are particularly objectionable precisely because they are seen to give an aura of respectability to the portrayal of the most grisly and violent assaults. Indeed, many observers have been outraged by the escalation of explicit sexuality and violence in 'Body Double' and have wondered why the movie received an $\mathrm{R}$ rather than an $\mathrm{X}$ rating. The reaction comes at a time when psychologists and others increasingly see a connection between violence shown on screen....and its actual enactment."

\section{Music/Rap}

“Obligatory Bondage Song." tvtropes, (page viewed on May 30, 2015) http://tvtropes.org/pmwiki/pmwiki.php/Main/ObligatoryBondageSong. This web page provides a long list of songs with BDSM lyrics.

"Fat Mike's Punk Rock Musical Features BDSM, Rape, and Catchy Tunes." Art Tavana. LA Weekly, March 10, 2015, http://www.laweekly.com/music/fat-mikes-punk-rock-musical-features-bdsm-rape-and-catchy-tunes-

5423033. “There's a point in every aging punk's career when they realize they've sold millions of records and yet somehow, only peroxide blonde teenagers with combat boots take them seriously. And so they grow up...For Michael Burkett, aka Fat Mike to those that grew up on his band NOFX, the decision to write a musical wasn't about aging gracefully - it was about writing an electrically charged score about S\&M-practicing crust punks...Home Street Home, the musical he penned with his dominatrix fiancé..., sheds light on the underbelly of BDSM power exchange (which stands for bondage, discipline and sadomasochism)...Home Street Home tells the brutal story of a 16-year-old runaway named Sue, who joins a tribe of BDSM-practicing crust punks that includes a dominatrix...With Home Street Home, Burkett is also making his self-professed role as BDSM missionary a bit more public. Growing up..., a 12-year-old Burkett would regularly flip through kinky stories in Penthouse Variations. It was 1979, four years before he would form NOFX at Beverly Hills High. Drooling over pictures of seductresses in garter belts, an erotic story of a husband being sexually dominated by his wife caught his eye...On NOFX's second LP S\&M Airlines (1989), the album cover included a dominatrix swinging a whip while riding a passenger plane. 'So stay in your missionary position, I hope that you get bored to death,' sings Burkett on the album's most memorable track, "Vanilla Sex."”

“Rihanna's S\&M video 'too explicit for daytime broadcast." Mark Sweney. Guardian (UK), May 9, 2011, http://www.theguardian.com/media/2011/may/09/rihanna-sm-video-too-explicit-for-daytime-broadcast. "Music TV broadcasters are to receive a dressing down from the media regulator after an unedited version of Rihanna's S\&M video, containing scenes of 'sexual bondage, dominance and sadomasochism', aired...when children could be watching.” 
“The Pop Singer as Ultimate Predator." Emily Esfahani Smith. Wall Street Journal, April 7, 2010, http://www.wsj.com/articles/SB10001424052702303411 604575167821091223394. "Take a quiz: Which feminist was the most-Googled female celebrity in 2009?...'She,' of course, is Lady Gaga, the 24-year-old idol... Her combination of sex, violence and death has got our music media frothing at the mouth with excitement...Vaudevillian and carnal, Lady Gaga has got the knack of sending rape-like fantasies-in songs and videos that double as catchy club hitsto the top of the charts...In her music video for 'Bad Romance,' two fierce women hold Gaga down, forcing a clear liquid into her mouth. The climax of the video hits when she's thrown at the feet of a group of tattooed men...'I want your revenge,' she howls. Her lyrics also celebrate themes of bondage and sadomasochism. In...'Poker Face,' Gaga sings, 'When it's love, if it's not rough it isn't fun.' In...'Bad Romance,' she craves a 'leather-studded kiss in the sand'-ouch! Then there's 'I Like it Rough,' which needs no explanation...In at least three of her videos, Gaga gruesomely murders men who are depicted as aggressors, in one case exalting in bed next to the charred carcass of her victim."

“Rock Bottom in the middle." Dan Aquilante. New York Post, April 26, 2010. "There's...the Rock Bottom Remainders, the notorious all-author band...There is some star potential in this outfit. Amy Tan has the rock-chick thing down totally. In her black dress, fishnet stockings and leather patrol cap, she played the dominatrix perfectly for her solo, 'These Boots Are Made For Walking.' Now Tan isn't the best singer, but she is very believable playing percussion with a cat-o'-ninetails on the derrieres of her bandmates."

“Janet doesn't show much discipline in 'Discipline." Glenn Gamboa. New York Newsday, February 26, 2008. "On the title track of her new 'Discipline'...album, over a loop of heavy breathing and...slow-grinding synth-funk, Janet Jackson coos, 'Take out your frustrations on me.'... Jackson...doesn't give any ground thematically on 'Discipline.,' named after a detailed account of her S\&M fantasy...It seems like her mind is holding her back more than any sort of leather restraints she wants to fantasize about..."

\section{Newspapers}

"Look for the 'Fifty Shades of Grey' film to whip up interest in the bondage scene." Justin Silverman. New York Daily News, January 9, 2015, http://www.nydailynews.com/life-style/50-shades-grey-film-roping-article-1.2071066. “The Fifty Shades of Grey book changed the public's perception of BDSM from something scary and unknown to something that couples could do together to spice up their sex life,' says Susan Wright, a spokesperson for the National Coalition for Sexual Freedom. 'The movie version will undoubtedly reach an even bigger audience.'...With the film out next month, the kinky arts of bondage and sexual role play known as BDSM are bound to find their way into more and more bedrooms....Miss $\mathrm{O}$ is a Manhattan dominatrix...'BDSM is a way for adults to have a roller-coaster ride that is not going to hurt your back or give you whiplash,' she says. 'It's an incredibly intense erotic experience."

"My Dad, the Pornographer." Chris Offutt. New York Times Magazine, February 5, 2015, http://www.nytimes.com/2015/02/08/magazine/my-dad-the-pornographer.html. 'My father's first published novel was 'Bondage Babes,'... His pay was $\$ 600$. The plot was a clever conceit. Someone had murdered a model for a 
bondage shoot, and the model's sister was investigating the crime by posing as a model herself, which allowed for soft-core descriptions of restrained women...The thickest notebook was designed strictly for B.D.S.M. novels with a list of 150 synonyms for 'pain.' Sections included Spanking, Whipping, Degradation, Pre-degradation, Distress, Screams, Restraints and Tortures..."

“Sex Toy Shops Prepare for Tie-Ins to 'Fifty Shades of Grey." Rachel Abrams. New York Times, February 1, 2015, http://www.nytimes.com/2015/02/02/business/media/50-shades-of-green-shops-prepare-fortie-ins-to-fifty-shades-of-grey-film.html. "'It is the biggest moment for our industry in popular culture...,' said Claire Cavanah, a co-founder of Babeland, an adult novelty retailer.”

“On the job: She's the boss." Jeremy Brown. New York Post, April 26, 2010, http://nypost.com/2010/04/26/on-the-job-shes-the-boss/. "Jennifer Hunter has always been good at telling men what to do...Hunter is the founder of Jennifer Hunter's Ivy League Educated Mistresses, a phone-sex line...I have a staff of eight, and these are extraordinarily fascinating, well-educated women...Our work runs the gamut - it could encompass any kink within the world of BDSM. One of my goals is to have an expert in every obscure subfield on my staff. So if a client wants to discuss impact play - like whips and floggers - there's a good possibility one or two have won competitions, and three or four ...really have the technical knowledge... My friends are very jealous...”

“Dominatrixes say their job can't be beat." Miguel Garcilazo \& Andrea Peyser. New York Post, October 20, 1992. “...Lurking throughout our city, disguised as college students and housewives, grandmas and everything else, a growing number of women are finding excitement, extra cash, and terrific clothes by leading double lives as practitioners of S\&M.”

"Whip yourselves into S\&M shape." Miguel Garcilazo \& Andrea Peyser. New York Post, October 19, 1992. “...Proper attire and accessories are critical to a meaningful fetish experience - and can help avoid social faux pas at black leather gatherings. Here, then, is a partial shopping list for the well-dressed dabbler in S\&M.”

\section{Television programs}

"Serial Killers Lose, Gain on Broadcast TV." Christopher Gildemeister. Parents Television Council, May 13, 2015, http://w2.parentstv.org/blog/ index.php/2015/05/13/serial-killers-lose-gain-on-broadcast-tv/. "For the last few seasons, graphically violent programs about serial killers have enjoyed a boom on broadcast TV. Recently, some networks have cancelled such shows...but sadly, other networks are jumping on the murder bandwagon. In January of 2013, Fox premiered the...drama The Following, about a serial killer who 'inspires' a cult of copycat killers to carry out murder sprees...Even a critic who admired The Following for its 'boldness' proclaimed that the show was a...'lightning rod for those who object to the escalation of brutal violence against women,' containing 'unrelenting misery and sadism that informs virtually every minute' with 'seemingly endless sadistic elements.' Similarly, last fall CBS launched Stalker, a series about detectives in an anti-stalking unit...Stalker gained a great deal of notoriety for its first episode, in which a woman is doused with gasoline and set on fire by her stalker, right outside her own home...Saddest of all is ABC. Up to now, the channel wholly owned by the Walt Disney Company has avoided the serial killer genre; but this week, the 
Alphabet Network announced the premiere next fall of Wicked City, a program that not only stars a serial killer, but features large amounts of sexual fetishism like bondage, torture, and rape."

"Desperate' Sex Secret: S\&M on Wisteria Lane." Marisa Guthrie. New York Daily News, February 19, 2015, http://www.nydailynews.com/archives/entertainment/desperate-sex-secret-s-m-wisteria-lane-article-1.611285. ("The decision to indulge in a little S\&M on network television was a collaborative effort..."

"The Objectification of Women through Modern American Sexual Culture." Brad Clancy. Horizons Newspaper, February 5, 2013, http://eraunews.com/final-approach/2013/02/05/the-objectification-of-women-throughmodern-american-sexual-culture/. "Oprah Winfrey...recently endorsed the book, 'Fifty Shades of Grey'...Her OWN cable network ran a TV special called 'Shades of Kink'..." the New York Tribune reported that "Oprah Winfrey will have [a program] on sadomasochism" (London, 1988).

“...How Hollywood Favors Adultery and Promiscuity Over Marital Intimacy on Prime-Time Broadcast TV." Special Report. Parents Television Council, 2008, http://www.parentstv.org/ptc/publications/reports/sexontv/ main.asp. "Today's prime-time television programming is not merely indifferent to the institution of marriage...it seems to be actively seeking to undermine marriage...Sex in the context of marriage is either non-existent on prime-time broadcast television, or is depicted as burdensome... By contrast, extra-marital or adulterous sexual relationships are depicted with greater frequency and overwhelmingly, as a positive experience...Major findings:...Although the networks shied away from talking about sex in the context of marriage, they did not shy away from discussions of masturbation, oral sex, anal sex...sex toys, bondage or kinky or fetishistic sex - there were 74 such references during the study period...Visual references to voyeurism...transvestites/transsexuals, threesomes, kinky sex, bondage and sadomasochism, and prostitution outnumbered visual references to sex in marriage by a ratio of $2.7: 1$."

"Playing With Fire at Seattle Sex Club," NBC News, January 14, 2008,http://www.nbcnews.com/id/22581503/ns/health-sexual_health/t/playing-fire-seattle-sex-club/\#.VWjs-89Vikp. "Becoming the msnbc.com Sexploration columnist proved to be much more of an education than Brian Alexander had ever anticipated. The questions from readers covered a huge range of sexual activities...'But they made me wonder what we were really up to in this country...,' So off he went, traveling the country..., reporting for a series we called America Unzipped and for his new book of the same name...Adapted from his... new book 'America Unzipped: In Search of Sex and Satisfaction,'...here's a look into a 'fire play' seminar held at [a 'sex club' in Seattle]: '...I had asked Allena, the director of...the Center for Sex Positive Culture, popularly known as the Wet Spot, to mentor me. I wanted to know what it felt like to be a member of a sex club where BDSM, fetish, swinging, pretty much the entire gamut of America's sexual menu, played out...I have come this evening specifically for the Fire Play Seminar. I'm not sure what fire play is, and having learned a lesson when I casually asked a woman at a fetish convention about genital torture, I have not asked for details. But Allena tells me...it is one of the edgier modes of BDSM action..."

“Something is criminal about gruesome 'Minds." Robert Bianco. USA TO$D A Y$, September 21, 2005, http://usatoday30.usatoday.com/life/television/reviews/2005-09-21-criminal-minds_x.htm. “There are minds I don't want to 
penetrate, crimes I don't want to see. And I've seen more than enough of them on TV to last a lifetime. You can choose for yourself what's most revolting about Criminal Minds...Perhaps it's the signature scene: a caged woman, duct tape on her eyes, crying, screaming, struggling, as the killer clips her already bloody nails to stop her from scratching at her blindfold. Or perhaps it's the plot itself, which plays like a how-to guide for sexual predators. Obviously, Criminal will find new crimes to explore in the future and equally gruesome ways to kill...and lately, the victim is always a woman. That's where these shows compete, as they struggle to find new, ever more disgusting forms of abuse."

“As crime thrillers go, 'The Inside' aims low." Robert Bianco. USA TODAY, June 7, 2005, http://usatoday30.usatoday.com/life/television/reviews/2005-0607-the-inside_x.htm. "How far inside the heart of darkness do you want a crime show to go? As the latest entrant on an already-too-long list of cop shows, The Inside attempts to separate itself from the procedural pack by traveling a darker path...Keep your remote handy, because Inside sets its tone with its first scene. A woman (these shows almost invariably choose to brutalize a woman for their introductory episodes) is lying on a bloody mattress with her face half cut off and the skin of her hands removed. Future episodes involve the slain partners of an S\&M master...The networks are clearly convinced there is a nearly insatiable appetite for this kind of drama - and forever more gruesome depictions of violence against women."

"TV's higher threshold of pain: The number of torture scenes on the networks last season grew...." Gregory M. Lamb. Christian Science Monitor, August 23, 2002, http://www.csmonitor.com/2002/0823/p13s02-altv.html. "A character on a TV show aimed at teens is shown being tied up and skinned alive, and his remains incinerated. In a spy drama, a woman has her teeth pulled out as a means of torture. In another TV drama, a captive, who can breathe only through straws in her nose, is chained, beaten, and finally suffocated....[S]cenes of torture and sadism appeared on network entertainment TV at a rate nearly double that over the previous two years. In a count requested by The Christian Science Monitor, Parents Television Council...logged 70 instances of scenes of graphic torture or sadism on network entertainment TV from Sept. 1, 2001, until earlier this month. In the two-year period previous to this, it logged 79."

“A little S\&M goes a long way." Peter Stack. San Francisco Chronicle, May 13, 1997. (“...documentary filmmaker...takes his camera into an underground New York City sadomasochistic parlor...Black leather, spikes, chromium studs, chains, whips, racks, surgical instruments and other accoutrements of the trade are everywhere in evidence as 'Fetishes' looks at customers getting their kicks from beatings, sucking on toes...or, in more extreme instances, submitting to asphyxiation or torture rituals.) [Author's note: This program aired on HBO.]

\section{Theater}

“Actors talk about erotically charged play 'Venus in Fur." Dan Kane. $R e$ pository, October 31, 2013, http://www.cantonrep.com/article/20131031/ENTERTAINMENT/131039962. “'It's very, very kinky,' actor Michael Brusasco said about 'Venus In Fur,'...opening Friday at the Cleveland Play House. 'There's leather and there's bondage, but you're not walking into a den of sadomasochism,' he said...His co-star, Vanessa Wasche, is certain 'Venus In Fur' will appeal to fans of 
'Fifty Shades of Gray.' 'They're going to love it,' she said. 'We're not as graphic, but it's definitely in the same neighborhood.' A critically acclaimed hit during its New York City runs, David Ives' play 'Venus In Fur' begins when an actress named Vanda (played by Wasche) shows up very late to audition for a play about a sadomasochistic relationship....A dominant-submissive roller-coaster ride ensues."

“Going to Extremes to Seek Dramatic Accuracy." Erick Piepenburg. New York Times, September 6, 2010, http://www.nytimes.com/2010/09/06/theater/06trust.html?_r=0. “...Mistress Kaya said her main motivation for helping the 'Trust' cast members was to make sure that the S\&M world was portrayed on-stage accurately and sympathetically.")

“XXX' Lets It All Hang Out." Barbara Hoffman. New York Post, 4/23/03, at http://nypost.com/2003/04/23/xxx-lets-it-all-hang-out/. "Now playing London: A sexually explicit play based on a Marquis de Sade book...'XXX,' a multimedia piece...features a naked cast of 'libertines' subjecting a young woman to sexual hazing - replete with rape, sodomy and incest. While the onstage sex is simulated which is how 'XXX,'...squeaked past London's vice squad - videos go where live actors fear to tread. Screens at the back of the stage depict every kind of fantasy and perversion."

\section{Videogames}

"Here's what makes torture in video games worse than on TV." Hayley Tsukayama. Washington Post, September 20, 2013, http://www.washingtonpost.com/blogs/the-switch/wp/2013/09/20/heres-what-makes-torture-invideo-games-worse-than-on-tv/. “...Rockstar's fifth major update to its popular series officially hit store shelves on Tuesday, and the company is already feeling heat from those who object to a graphic torture scene... The Guardian reported that groups such as Freedom from Torture and Amnesty have criticized Grand Theft Auto $\mathrm{V}$ for the scene, which has players electrocute a man, pull out his teeth and use other various torture implements, e.g. sledgehammers, to get information...The scene is gruesome...though admittedly not too far afield from what we've already seen in movies or...network TV...So what makes Grand Theft Auto V any different? The key may lie in what Freedom from Torture chief executive Keith Best told the British paper: 'Rockstar North has crossed a line by effectively forcing people to take on the role of a torturer and perform a series of unspeakable acts if they want to achieve success in the game."

"How Evil Should a Video Game Allow You to Be?" Simon Parkin. New Yorker September 17, 2013. http://www.newyorker.com/tech/elements/howevil-should-a-video-game-allow-you-to-be. “...A 2011 Supreme Court ruling recognized that video games, like other forms of art and entertainment, are protected by the First Amendment as a form of speech...As such, Rockstar, the developer of Grand Theft Auto V, the latest entry in the long-running series...could include a prolonged interactive depiction of torture without fear of censorship. Nevertheless, the '24'-esque scene, which requires players to rotate the game controller's sticks in order to tug out the victim's teeth with pliers, has inspired debate...Video-game violence is, like all onscreen violence, an act of play...In Grand Theft Auto V, the ambition is not only to tell a story but also to create a fully functioning social universe within a faithful depiction of a contemporary city...In previous Grand Theft Auto titles, for example, players were able to visit strip clubs, 'kill' innocents and, 
in one notorious anecdote, pay for a prostitute and, after having sex with her, murder her to reclaim the money...Last month, a user on a Grand Theft Auto V forum asked whether players would be able to rape women in the game. In the post, which was widely shared on social media, he wrote, 'I want to have the opportunity to kidnap a woman, hostage her, put her in my basement and rape her everyday, listen to her crying, watching her tears.' This is alarming but, in a game that prides itself on player-led freedom and opportunity within virtual, victimless but violent worlds, is it unreasonable? If this freedom is necessary to maintain the artifice of the world, the designer surely has a responsibility to engineer the victim's reactions in order to communicate something of the pain and damage inflicted."

“Should you take 'Torture' seriously?" Winda Benedetti. NBCNews.com. June 24, 2008, http://www.nbcnews.com/id/25337373/ns/technology_and_science-games/t/should-you-take-torture-seriously/\#.VWpoWM9Viko. "The young man responsible for 'The Torture Game 2' doesn't think you should take his little creation too seriously. Sure, it's a computer game in which you, the player, are asked to do horrible, unspeakable...things to a defenseless man-like person tied up in some dark room from which he has absolutely no hope of escape...Here, a pale, androgynous human hangs from ropes on the computer screen before you. Among the devices at your disposal - chainsaw, a razor blade, spikes, a pistol...There's little in the way of instructions and no points to be earned. Instead, this dangling ragdoll offers you a canvas to do with what you will - stab him with spikes, flay the skin from his body with a razor, pull his limbs off with your bare hands...No matter what you do to him, he never screams and his expression never changes. He only utters a vague 'uuungh' when you've inflicted enough damage to kill him. And that's pretty much it."

“RapeLay' video game goes viral amid outrage” Kyung Lah. CNN, March 31, 2010, http://www.cnn.com/2010/WORLD/asiapcf/03/30/japan.video. game.rape/. "...That is when you, the player, can choose your method of assault. With the click of your mouse, you can grope her and lift her skirt. Then you can follow her..., assaulting her sister and her mother. As you continue to play, 'friends' join in and in a series of graphic, interactive scenes, you can corner the women, rape them again and again...'This was a game that had absolutely no place on the market,' said Taina Bien-Aime of women's rights organization Equality Now...What happened to RapeLay is an example, said Bien-Aime, of why Japan needs to police game makers. 'It's obviously very difficult to curtail activity on the Internet. But the governments do have a role...,' she said, adding that they were calling for the Japanese government 'to ban all games that promote and simulate sexual violence, sexual torture, stalking and rape against women and girls. And there are plenty of games like that.' Those games are known as 'hentai games.' Almost all feature girlish-looking characters. Some of the games are violent -- depicting rape, torture and bondage in detail."

\section{ACKNOWLEDGMENTS}

Dignity thanks the following students for their time in editing this document: Hope Simas, philosophy and gender and women's studies major, and Lily Lachapelle, psychology and gender and women's studies major and Arabic minor. 


\section{AUTHOR BIOGRAPHY}

Robert Peters served as president of Morality in Media (MIM) from 1992-2011 and as assistant director of MIM's National Obscenity Law Center from 1987-1992. Mr. Peters is now president emeritus of Morality in Media. Morality in Media, Inc. (DBA National Center On Sexual Exploitation) has a website at https//endsexualexploitation.org/

\section{RECOMMENDED CITATION}

Peters, Robert. (2018). Sadomasochism: Descent into Darkness: Annotated Accounts of Cases, 1996-2014. Dignity: A Journal of Sexual Exploitation and Violence. Vol. 3, Issue 2, Article 2. https://doi.org/10.23860/dignity.2018.03.02.02

\section{REFERENCES}

. (2011, October 12). Inside sex fiend's terrifying trailer of torture.... Daily Mail. . (2011, October 17). NY Asst. AG quits after story claiming she was paid to be dominatrix. CBSNews, http://newyork.cbslocal.com/2011/10/17/ny-asst-agquits-after-story-claiming-she-was-paid-to-be-dominatrix/)

. (2013, May 14). Oxford rape and trafficking: Who were the victims? BBC News http://www.bbc.com/news/uk-england-21445538)

Abrams, Rachel. (February 1, 2015.) "Sex toy shops prepare for tie-ins to Fifty Shades of Grey. New York Times.

http://www.nytimes.com/2015/02/02/business/media/50-shades-of-greenshops-prepare-for-tie-ins-to-fifty-shades-of-grey-film.html.

Andrews, Steve. (2015, March 26). After execution, DNA links Oba Chandler to another murder. The Tampa Bay Times, http://www.tampabay.com/news/publicsafety/crime/oba-chandler-dies-for1989-rapes-murders-of-mother-teen-daughters/1201940) reported.

Balut, Dave. (2005, October 28). Jurors see graphic photos of nude gay men tied to...bed. WSTP TV, http://archive.wtsp.com/news/story.aspx?storyid=20491

Bennetts, Leslie. (July 18, 2011). The growing demand for prostitution," Newsweek, http://www.newsweek.com/growing-demand-prostitution-68493.

Brick, Michael. (2006, March 24). 2 guilty in 2003 killing of college student. The New York Times

Chemerinsky, Erwin. (February 18, 2015). Grey exposes why obscenity laws should be repealed," Orange County Register.

http://www.ocregister.com/articles/obscenity-651616-sexually-explicit.html).

Cline, Victor. (2001). Pornography's effects on adults and children, Morality in Media. http://www.scribd.com/doc/20282510/Dr-Victor-Cline-Pornography-s-Effectson-Adults-and-Children\#scribd.

Dines, Gail. (February 18, 2015). Review: Watching 50 Shades of Grey is torture, Feminist Current. http://feministcurrent.com/10776/review-watching-50-shades-of-greyis-torture/.

Eligon, John. (2007, June 7). "Rape victim recounts a night of terror.” The New York Times.

Geberth, Vernon J. (2010) Sex-related homicide and death investigation: Practical and clinical perspectives, 2nd ed., CRC Press, pp.483-487.

Fox, James Alan. (2014, October 23). “Serial Killers Find Prostitutes an Easy Prey,” USA Today. 
Guse, Maren. (2013, July 17). [Defendant] pleads guilty in Clay murder and kidnapping case, CNY Central http://www.cnycentral.com/news/story.aspx?id=922505\#.VVJXlvlViko).

Harding, Margaret. (201, October 22). "Butler woman describes torture at hand of 'predator'," Pittsburgh Tribune, http://triblive.com/x/pittsburghtrib/news/regional/s_763205.html\#axzz3Xt0Ay fGa.]

Hollandsworth, Skip. (2011, April). “The lost boys.” Texas Monthly, http://www.texasmonthly.com/story/lost-boys-0/page/0/5.

Hughes, Donna M. (July 1, 2010). Sex trafficking of women for the production of pornography. Citizens Against Trafficking. https://works.bepress.com/donna_hughes/112/

Hughes, Donna M. (April 3, 2015). "Pretty Woman': 25 years of lies about prostitution.” Providence Journal, April 3, 2015. https://works.bepress.com/donna_hughes/44/

Johnson, Craig. (August 11, 1985). NY Native.

Aaron Kheriaty. (February 17, 2005). "Hooked up and tied down: The neurological consequences of sadomasochism," Witherspoon Institute. http://www.thepublicdiscourse.com/2015/02/14470/.

FBI. (1992, August 3) http://vault.fbi.gov/jeffrey-lionel-dahmer/jeffrey-lionel-dahmerpart-03-of-19).

Fox, James, Alan (2014, October 23). Serial killers find prostitutes an easy prey.” USA Today.

Gillespie, Pat. (2007, October 12). Ex-DCF employee gets three years in prison. The News Press.

Green, Tavia. (2014, September 4). "Homicide cases get murder indictments." The LeafChronicle.

Hoffman, Bill. (1991, March 3). How FBI’s 'Jodie' got her man.” New York Post.

Hollandsworth, Skip. (2011, April). "The lost boys," Texas Monthly, http://www.texasmonthly.com/story/lost-boys-0/page/0/5.]

Johnson, Richard. (1994, September 10). Pol's pained over S\&M show grant. The New York Post.

Kaminsky, Jonathan. (2011, July 12). Will [Defendant's] Gorean bondage fetish set him free? Seattle Weekly http://www.seattleweekly.com/2011-07-13/news/will-johnhauff-s-gorean-bondage-fetish-set-him-free/)

Kramer, Mark. (1994, April 21). Sex and mortality are eternally linked... New York Newsday.

Lamm, Greg. (1987, October 21). 4 arrested in torture, abduction of woman. The Tampa Tribune.

Lewak, Doree. (July 12, 2012). “The hot sex text.” New York Post, http://nypost.com/2012/07/12/the-hot-sex-text/.

London, Herbert. (1988, July 27). "The lack of taste in talk shows has made viewers shockproof," New York Tribune.

Malm, Sara. (February 1, 2015). Fifty Shades of Grey will be raunchiest film in more than a DECADE with 20 minutes of sex in its 100-minute running time," Daily Mail (UK). http://www.dailymail.co.uk/news/article-2935163/Dornan-hopes-Greyrole-passable.html\#ixzz3Qb361vQE. 
MacKinnon, Catharine \& Dworkin, Andrea. (1983, December 12-13). The Minneapolis Hearings, In Catharine MacKinnon and Andrea Dworkin Eds., In Harm's Way: The Pornography Civil Rights Hearings; 1997.

MacKinnon, Catharine \& Dworkin, Andrea. (1992, March 16). The Massachusetts Hearing, Boston, In Catharine MacKinnon and Andrea Dworkin Eds., In Harm's Way: The Pornography Civil Rights Hearings.1997.]

Martinez, Edecio. (2009, November 2). [Defendant] cruised sex fetish site.... CBS News, http://www.cbsnews.com/news/anthony-sowell-cruised-sex-fetish-site-whiledead-bodies-rotted-in-his-cleveland-home/)

McGreal, Chris. (2012, May 26). Has the alphabet murderer finally been caught? The Guardian, http.//www.theguardian.com/world/2012/may/26/alphabetmurderer

McKelway, Bill. (2015, May 1). Guilty plea, new details in sex slave case. The TimesDispatch, http://www.richmond.com/news/local/crime/article_3fd2d112-be215a05-8ba2-be4e94e507e9.html)

Murphy, Sean. (2003, March 8). Family of killer describes awkward youth. Associated Press.

Naifeh, Steven \& Smith, Gregory White. (1995). A Stranger in the Family: A True Story of Murder, Madness, and Unconditional Love, Penguin books.

O'Brien, John. (2015, May 8). Amish girls' kidnappers staked them out beforehand, drugged them after, prosecutor says. The Syracuse.com.

Peters, Robert. (March 24, 2004). Link between pornography and violent sex crimes, https://www.academia.edu/10232415/Link_Between_Pornography_and_Violen t_Sex_Crimes.

Peters, Robert. (2009). How adult pornography contributes to sexual exploitation of children, Morality in Media. pornharmsresearch.com.

Peters, Robert, Laura Lederer \& Shane Kelly. (2012). The slave and the porn star: Sexual trafficking and pornography," Protection Project Journal of Human Rights and Civil Society; 5:1-21. http://www.ifsnetwork.org/Portals/4/docs/TPP-J-HR-CivSocy_Vol-5_2012-w-cover1.pdf

Peterson, Helen. (2000, October 24). "Jury told man killed three of 6 he raped." New York Daily News

Press Release. (August 21, 2014). Reading Fifty Shades linked to unhealthy behaviors, Michigan State University. http://msutoday.msu.edu/news/2014/reading-fiftyshades-linked-to-unhealthy-behaviors.

Pulver, Andrew. (February 2, 2015). Fifty Shades of Grey movie slapped with 18 certificate...," Guardian (UK), http://www.theguardian.com/film/2015/ feb/02/fifty-shades-of-grey-movie-slapped-with-18-certificate.

Resnek, Joshua \& Szechenyi, Christopher. (1997, June 18). The boy next door. The Improper Bostonian.

Schiappa, Cliff. (2001, June). Serial killer J. R. Robinson's sinister alter ego.” Vanity Fair, http://www.vanityfair.com/news/2001/06/jr-robinson-serial-killer.

Silbert M.H. \& Pines A.M. "Pornography and Sexual Abuse of Women," Sex Roles, 10:857-868 (1984).

Smith, Deann \& Bradley. (2006, June 30). Spicer probe leaves questions. The Kansas City Star.

Strauss, Gary. (2013, July 26). Castro in plea deal. 'I'm addicted to pornography.' USA TODAY. 
Steed, Judy. (1995, September 2). A taste for porn shaped 'ordinary' sexual sadist. Toronto Star.

Stone, Michael. (2010, March). Sexual sadism: A portrait of evil." J Am Acad Psychoanal Dyn Psychiatry, 38(1):133-57, http://66.199.228.237/boundary/hematomania/sexual_sadism_a_portrait_of_ evil.pdf

Weir, Richard. (2003, June 4). "She fights off rapist: Victim's nails torn off in attack." New York Daily News, http://www.nydailynews.com/archives/news/fightsrapist-victim-nails-torn-attack-cops-hunt-sex-offender-article-1.672213.

Woan, Sunny. (2008). White sexual imperialism: A theory of Asian feminist jurisprudence. Washington and Lee Journal of Civil Rights and Social Justice. Vol. 14(2):275, 295-296,

Woodrow, Jane Carter. (2011, July 3). A killer and a sex offender, drawn together by evil. Express (UK), http://www.express.co.uk/expressyourself/256432/A-killer-anda-sex-offender-drawn-together-by-evil.

Zahn, Drew. (February 13, 2015) Evidence: '50 Shades of Grey' marketed to children.” WND, http://www.wnd.com/2015/02/evidence-50-shades-of-grey-marketed-tochildren/. 